\title{
On the Diversity of Phyllodocida (Annelida: Errantia), with a Focus on Glyceridae, Goniadidae, Nephtyidae, Polynoidae, Sphaerodoridae, Syllidae, and the Holoplanktonic Families
}

\author{
Daniel Martin ${ }^{1, *} \mathbb{C}$, Maria Teresa Aguado ${ }^{2, *}$, María-Ana Fernández Álamo ${ }^{3}$, Temir Alanovich Britayev ${ }^{4}(\mathbb{D}$, \\ Markus Böggemann ${ }^{5}$, María Capa ${ }^{6}{ }^{(0}$, Sarah Faulwetter ${ }^{7,8}{ }^{(0)}$, Marcelo Veronesi Fukuda ${ }^{9}{ }^{\circledR}$, Conrad Helm ${ }^{2}$, \\ Monica Angelica Varella Petti ${ }^{10}{ }^{\mathbb{D}}$, Ascensão Ravara ${ }^{11}$ and Marcos A. L. Teixeira ${ }^{12,13}$ (D)
}

check for updates

Citation: Martin, D.; Aguado, M.T.; Fernández Álamo, M.-A.; Britayev, T.A.; Böggemann, M.; Capa, M.; Faulwetter, S.; Fukuda, M.V.; Helm, C.; Petti, M.A.V.; et al. On the Diversity of Phyllodocida (Annelida: Errantia), with a Focus on Glyceridae, Goniadidae, Nephtyidae, Polynoidae, Sphaerodoridae, Syllidae, and the Holoplanktonic Families. Diversity 2021, 13, 131. https://doi.org/ 10.3390/d13030131

Academic Editor: Bert W. Hoeksema

Received: 5 February 2021

Accepted: 8 March 2021

Published: 17 March 2021

Publisher's Note: MDPI stays neutral with regard to jurisdictional claims in published maps and institutional affiliations.

Copyright: (c) 2021 by the authors. Licensee MDPI, Basel, Switzerland. This article is an open access article distributed under the terms and conditions of the Creative Commons Attribution (CC BY) license (https:// creativecommons.org/licenses/by/ $4.0 /)$.
1 Centre d'Estudis Avançats de Blanes (CEAB-CSIC), 17300 Blanes, Spain

2 Animal Evolution \& Biodiversity, Georg-August-Universität, 37073 Göttingen, Germany; chelm@uni-goettingen.de

3 Laboratorio de Invertebrados, Facultad de Ciencias, Universidad Nacional Autónoma de México, Ciudad de México 04510, Mexico; mafa@ciencias.unam.mx

4 A. N. Severtzov Institute of Ecology and Evolution (RAS), 119071 Moscow, Russia; britayev@yandex.ru

5 Fakultät II-Natur- und Sozialwissenschaften Department, University of Vechta, Fach Biologie, Driverstraße 22, 49377 Vechta, Germany; markus.boeggemann@uni-vechta.de

6 Departament de Biologia, Universitat de les Illes Balears, 07122 Palma, Spain; maria.capa@uib.es

7 Department of Geology, University of Patras, 26504 Patras, Greece; sarifa@hcmr.gr

8 Hellenic Centre for Marine Research, Institute of Oceanography, 19013 Anavyssos, Greece

9 Museu de Zoologia, Universidade de São Paulo, São Paulo 04263-000, Brazil; mvfukuda@usp.br

10 Instituto Oceanográfico, Universidade de São Paulo, São Paulo 05508-120, Brazil; mapetti@usp.br

11 Centre for Environmental and Marine Studies (CESAM), Departamento de Biologia, Campus de Santiago, Universidade de Aveiro, 3810-193 Aveiro, Portugal; aravara@ua.pt

12 Centre of Molecular and Environmental Biology (CBMA), Departamento de Biologia, Universidade do Minho, Campus de Gualtar, 4710-057 Braga, Portugal; mark-us_teixeira@hotmail.com

13 Campus de Gualtar, Institute of Science and Innovation for Bio-Sustainability (IB-S), Universidade do Minho, 4710-057 Braga, Portugal

* Correspondence: dani@ceab.csic.es (D.M.); aguadomolina@uni-goettingen.de (M.T.A.); Tel.: +34-636-046-003 (D.M.); +49-(0)551-39-25536 (M.T.A.)

Abstract: Phyllodocida is a clade of errantiate annelids characterized by having ventral sensory palps, anterior enlarged cirri, axial muscular proboscis, compound chaetae (if present) with a single ligament, and of lacking dorsolateral folds. Members of most families date back to the Carboniferous, although the earliest fossil was dated from the Devonian. Phyllodocida holds 27 well-established and morphologically homogenous clades ranked as families, gathering more than 4600 currently accepted nominal species. Among them, Syllidae and Polynoidae are the most specious polychaete groups. Species of Phyllodocida are mainly found in the marine benthos, although a few inhabit freshwater, terrestrial and planktonic environments, and occur from intertidal to deep waters in all oceans. In this review, we (1) explore the current knowledge on species diversity trends (based on traditional species concept and molecular data), phylogeny, ecology, and geographic distribution for the whole group, (2) try to identify the main knowledge gaps, and (3) focus on selected families: Alciopidae, Goniadidae, Glyceridae, Iospilidae, Lopadorrhynchidae, Polynoidae, Pontodoridae, Nephtyidae, Sphaerodoridae, Syllidae, Tomopteridae, Typhloscolecidae, and Yndolaciidae. The highest species richness is concentrated in European, North American, and Australian continental shelves (reflecting a strong sampling bias). While most data come from shallow coastal and surface environments most world oceans are clearly under-studied. The overall trends indicate that new descriptions are constantly added through time and that less than $10 \%$ of the known species have molecular barcode information available.

Keywords: polychaetes; species diversity; molecular diversity; phylogeny; ecology; distribution 


\section{Introduction}

The order Phyllodocida was first formulated as monophyletic by Dales [1], based on the muscular pharynx shared by the members of the clade. Later it was supported based on characters such as the ventral position of sensory palps, the presence of anterior enlarged cirri, the loss of dorsolateral folds (i.e., protrusible dorsolateral walls of the foregut), the presence of an axial muscular proboscis and the presence of compound chaetae with a single ligament [2]. It was further considered paraphyletic [3], but its monophyly has been recovered with strong support by modern molecular approaches $[4,5]$. Phyllodocida, like most soft-bodied polychaetes, is not well represented in the fossil record, but fossil specimens have been described from several families [3,6]. Most extant groups first appear in the Carboniferous [7], although Arkonips topororum Farrell \& Briggs, 2007 [8], from the Devonian, seems to group within Phyllodocida, thus possibly constituting the earliest known member of the clade.

As currently delimited, Phyllodocida is one of the largest and most diverse polychaete clades. It includes Aphroditiformia, Glyceriformia, Nereidiformia, and Phyllodociformia, each with several generally well-defined clades interpreted with the taxonomic hierarchical level of family, but also several unplaced taxa (as Phyllodocida incertae sedis). In total, Phyllodocida holds more than 6600 species-level taxa, of which around 4627 are currently considered valid in the World Polychaeta Database (WPD) [6], where 28 families (excluding Pholoidae, a synonym of Sigalionidae [9]) and 566 valid genera are listed. However, higher taxa are constantly being revised as more insights from molecular methods and new morphological data (e.g., through microCT, confocal imaging, etc.) become available $[10,11]$.

Phyllodocida is a ubiquitous group of annelids. Most members are typically marine benthic, but a small fraction also inhabit brackish waters, freshwater, and even terrestrial environments, and a few are holoplanktonic [12]. Benthic forms live as in- or epifauna in muddy and sandy bottoms, mixed sediments, under rocks, or hiding in crevices in hard surfaces, from shallow littoral to the deepest marine bottoms [3], including extreme environments such as hydrothermal vents [13-15]. Most species are free living (especially within Nereidiformia and Phyllodociformia), some burrowing in sediments (e.g., Glyceriformia), and some are tubicolous (e.g., some Aphroditiformia) [12]. Most species are 'active-searching' or 'sit-and-wait' predators, feeding on other invertebrates (e.g., among Nereidiformia, Phyllodociformia, Glyceriformia, or Aphroditiformia); some may be carrion-feeders and herbivorous, rarely alternate these trophic guilds with filter feeding (e.g., among Nereidiformia) [12]. Moreover, a large number of species (particularly within Aphroditiformia) live symbiotically with other benthic species (including echinoderms, cnidarians, decapods and, even, other polychaetes) [16,17].

Phyllodocida are among the most phylogenetically diverse groups of organisms [18,19], while the key roles they play in marine ecosystems lead them to be a demanding component for morphology-based biomonitoring [20]. Moreover, molecular tools are also being increasingly integrated in regular and large-scale biomonitoring initiatives thanks, for instance, to high-throughput sequencing technologies [21,22]. However, to achieve their full potential, the creation and constant improvement of DNA barcode libraries is an essential task to support species identification. Together with the emergence of DNA metabarcoding and eDNA-based approaches for ecological and biological research [23], the need to update molecular libraries becomes crucial [24] not only for already known species, but also for the remarkable hidden diversity that is being continuously revealed with the support of molecular data [25-27]. Taking this into account, the first part of this paper aims at analyzing all public Barcode Of Life Data System (BOLD) [28] data to assess the worldwide DNA barcode coverage for the species of Phyllodocida. This will allow us to evaluate taxonomic uncertainties, as well as to analyze species phylogenetic diversity, to improve DNA metabarcoding studies at the taxonomic assignment step [24] and to highlight the existing knowledge gaps and the main still-pending taxonomic revisions. 
The literature on the species of the order is immense, as can be partly shown just by going through the list of authors describing new species compiled in the WPD [6]. In addition, there are also numerous papers on anatomy, biology, ecology, and other disciplines (some of them, but certainly not all, listed in the present paper). Such a vast amount of information makes reviewing diversity-related aspects in the group challenging. In this sense, we will also focus on providing wide-spectrum information on different topics dealing with a selected group of representative families (and here we use Linnean ranks for practical purposes) within Phyllodocida, mainly targeting diversity-related aspects. Relying on the different expertise of the involved authors, the groups included in this paper are the two families of Glyceriformia (i.e., Goniadidae and Glyceridae), the holoplanktonic Alciopini, Iospilidae, Lopadorrhynchidae, Pontodoridae, Tomopteridae, Typhloscolecidae and Yndolaciidae, and the families Nephtyidae, Polynoidae, Sphaerodoridae, and Syllidae.

\section{Materials and Methods}

\subsection{Species List}

Species and subspecies for Phyllodocida were downloaded from the WPD [6], a subset of the World Register of Marine Species (WoRMS) [29] on 2020-09-06, using the Worms library [30] in R 3.6.1 (R Foundation, Vienna, Austria) [31]. Subsequently, taxa with an unclear taxonomic status (nomen nudum, interim unpublished, temporary name, uncertain, taxon inquirendum) were excluded. Alternative representations of names were treated as objective synonyms (all data and scripts available via figshare-DOI: https: / / doi.org/10.6084/m9.figshare.13678570, posted on 2 March 2020).

\subsection{Occurrence Records}

Distribution records were downloaded on 2020-04-21 from the Ocean Biodiversity Information System (OBIS) [32] using the library Robis [33] in R and additional records were downloaded from the Global Biodiversity Information Facility (GBIF) via the online search interface [34]. The two datasets were joined and duplicate records (same species sampled at the same location on the same date) were excluded. Only species-level records were considered, and they were matched against the WPD [6] to obtain the currently accepted names. Species with an unclear taxonomic status (i.e., nomen nudum, interim unpublished, temporary name, uncertain, taxon inquirendum) and fossil records were excluded. Coordinates were rounded to two decimal places to obtain the same precision for all coordinates. Points falling on land were removed with the Obistools package [35] in $\mathrm{R}$ (with a buffer of $5 \mathrm{~km}$ to allow for imprecision in the coastline and to include lagoons and swamps). For depth analyses, points deeper than 10,902 m were excluded. Depths in OBIS are given as positive numbers, any negative numbers were checked manually and converted to true depths. This resulted in a dataset of 538,599 records, covering all families of Phyllodocida, all geographic regions and latitudes and all depths.

\subsection{Biogeographic Distribution}

We used a system of biogeographic regions dividing the world's ocean into 32 realms [36]. As these realms do not constitute regions of similar sizes or depths, for a finer resolution, a hexagon grid with equally sized cells of ca. $69,967.85 \mathrm{~km}^{2}$ surface was created using the $d g g r i d R$ package in $\mathrm{R}$ [37]. For analyses of latitudinal patterns, data were grouped into $5^{\circ}$ latitudinal bands. Depth distributions were analyzed within depth zones from intertidal to hadal (intertidal and shallow subtidal: $<10 \mathrm{~m}$, high subtidal: $10-100 \mathrm{~m}$, low subtidal: 100-200 m, continental slope: 200-1000 m, bathyal: 1000-4000 m, abyssal: 4000-6000 m, hadal: $>6000 \mathrm{~m}$ ). No standardization of the ocean surface or water column volume corresponding to these intervals was performed, as the scope of the analysis was merely descriptive.

As the data exhibit a strong sampling bias towards the coasts of Europe and North America and species richness is strongly correlated with the number of records, the expected number of species for a random sample of 50 occurrence records (ES50) [38] for each 
observational unit (hexagon cell/region/latitudinal band/depth interval) was calculated using the calc function by OBIS in R (https:/ / github.com/iobis/ebsa/blob/master/lib.R, accessed on 20 April 2020) using frequencies of species per observational unit in place of abundances.

Uniqueness of species was calculated by determining which percentage of the total number of species in a biogeographic area were unique for that area (i.e., did not occur in any other biogeographic area).

\subsection{Non-Indigenous Species}

A list of non-indigenous species and their regions of introduction was compiled from the World Register of Introduced Marine Species (WriMS) [39] and additional literature sources [40-45] and plotted using shapefiles for regional seas [46]. Non-indigenous species are defined as "species introduced outside of their natural range (past or present) and outside of their natural dispersal potential" [47].

\subsection{Data Mining and BOLD Dataset Creation}

We uploaded a list of selected taxa of Phyllodocida to BOLD [28] (CL-MTVPP, DOI: https://doi.org/10.6084/m9.figshare.13678570, posted on 2 March 2020), comprising 27 families, 566 genera, 4680 species, and 161 subspecies. We also uploaded a list of species considered non-indigenous (CL-MTAPP, DOI: https:/ / doi.org/10.6084/m9.figshare.13 678570, posted on 2 March 2020), containing 13 families, 44 genera, 62 species, and one subspecies (Table 1 ). We used the BOLD platform to search for all the publicly available COI-5P sequences from Phyllodocida and GenBank to create the dataset DS-MTAPP (DOI: https:/ / doi.org/10.5883/DS-MTAPP, posted on 2 March 2020) for the analysis. A species was considered successfully barcoded if at least one COI-5P sequence ( $>300 \mathrm{bp}$ ) was available. COI sequences without information on species name and with less than 300 base pairs, lacking BINs and flagged for contamination, stop codons or indels were subsequently removed. We started from a dataset containing 11,799 sequences corresponding to 1418 species. However, only 7831 barcodes (from 830 species) were publicly available. Using them we apply the methods described above to obtain a final dataset (also used for statistical analyses) that included 6361 DNA barcodes from 620 species (3509 exclusive to BOLD and 2852 mined from GenBank making). Since most GenBank records lack metadata (e.g., GPS coordinates, depth), we excluded GenBank-only records from the species list to generate a new dataset with 3509 records that was also uploaded to BOLD (DS-MTBPP, DOI: https:/ / doi.org/10.5883/DS-MTBPP, posted on 2 March 2020) to analyze bathymetric patterns in barcode availability. 


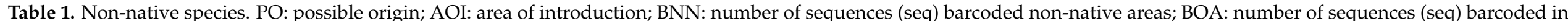
other areas.

\begin{tabular}{|c|c|c|c|c|c|c|}
\hline Family & Species & TL & AOI & BNN & BOA & Source \\
\hline Chrysopetalidae & Bhawania goodei & Bermuda & Mediterranean Sea & & Florida Keys, USA (1 seq) & [39] \\
\hline & & - & & & $\begin{array}{c}\text { Artic Russia (9 seq)—Kandalaksha } \\
\text { Bay, Velikaya Salma Strait; }\end{array}$ & \\
\hline Glyceridae & Glycera capitata & Greenland & Black Sea & & $\begin{array}{l}\text { NAmerica (10 seq)_-Hudson Bay, } \\
\text { Canada; Saglek Fiord, Canada; } \\
\text { Devon Island, Canada; Alaska, } \\
\text { USA; Ratnagiri coast, India (2 seq) }\end{array}$ & {$[40]$} \\
\hline Hesionidae & Podarkeopsis capensis & South Africa & E Mediterranean & & N Spain (1 seq) & [39] \\
\hline Nephtyidae & Inermonephtys inermis ${ }^{(1)}$ & Florida Keys, USA & Red Sea & & China (3 seq)—Laizhou Bay & [40] \\
\hline Nereididae & Alitta succinea & Cuxhaven, Germany & $\begin{array}{c}\text { Australian Exclusive Economic } \\
\text { Zone; Argentina; Caribbean Sea; } \\
\text { Hawaii; Japan; South Africa; } \\
\text { USA Pacific }\end{array}$ & & USA Atlantic (8 seq) & {$[39,40]$} \\
\hline Nereididae & Alitta virens ${ }^{(2)}$ & $\begin{array}{c}\text { Manger (N Bergen, } \\
\text { Norway) }\end{array}$ & Baltic Sea, North Sea & & $\begin{array}{c}\text { Kandalaksha Bay, Velikaya Salma } \\
\text { Strait, Russia Arctic ( } 3 \text { seq) } \\
\text { St. Andrews, Blockhouse, USA } \\
\text { Atlantic (50 seq) }\end{array}$ & [40] \\
\hline Nereididae & Leonnates decipiens & $\begin{array}{l}\text { Gulf of Mannar, Indian } \\
\text { Ocean }\end{array}$ & Mediterranean & & India (1 seq)—Mumbai coast & [40] \\
\hline Nereididae & Namalycastis abiuma & $\begin{array}{c}\text { Santa Catarina Island, } \\
\text { Brazil }\end{array}$ & Hawaii & & $\begin{array}{c}\text { China (2 seq)_Yuandang Lake in } \\
\text { Xiamen; India } \\
\text { (5 seq)—Kadinamkulam estuary }\end{array}$ & {$[40]$} \\
\hline Nereididae & Neanthes acuminata ${ }^{(3)}$ & Gulf of Naples, Italy & USA Pacific & $\begin{array}{l}\text { S California, USA } \\
\text { (54 seq) }\end{array}$ & $\begin{array}{l}\text { Portugal (5 seq); Hawai (1 seq), USA } \\
\text { Atlantic, Connecticut (5 seq); Baja } \\
\text { California, Pacific Mexico (6 seq) }\end{array}$ & [40] \\
\hline Nereididae & Perinereis aibuhitensis & Palau, Pacific Ocean & Japan, Portugal & & $\begin{array}{l}\text { No GPS data (7 seq); Zhoushan } \\
\text { Zhujiajian, China (1 seq) }\end{array}$ & {$[40]$} \\
\hline Nereididae & Perinereis nuntia & Gulf of Suez & Mediterranean Sea & & Pari Island, Indonesia (1 seq) & {$[40]$} \\
\hline Nereididae & Pseudonereis anomala & Gulf of Aden & Mediterranean Sea & & Queensland, Australia (21 seq) & [39] \\
\hline Paralacydoniidae & Paralacydonia paradoxa ${ }^{(4)}$ & $\begin{array}{c}\text { Monaco, Mediterranean } \\
\text { Sea }\end{array}$ & Red Sea & & Bohai Sea, China (18 seq) & {$[39,40]$} \\
\hline Phyllodocidae & Eumida sanguinea ${ }^{(5)}$ & Denmark (Kattegat) & Hawaii & & $\begin{array}{c}\text { NE Atlantic (29 seq)—Scilly islands, } \\
\text { Great Britain; Finnmark, Norway; } \\
\text { Bergen, Norway; Bohuslän, Sweden; } \\
\text { Helsingör, Denmark }\end{array}$ & [40] \\
\hline
\end{tabular}


Table 1. Cont.

\begin{tabular}{|c|c|c|c|c|c|c|}
\hline Family & Species & TL & AOI & BNN & BOA & Source \\
\hline Pilargidae & Sigambra parva & S South Africa & E Mediterranean & \multirow{8}{*}{$\begin{array}{l}\text { Port of Los } \\
\text { Angeles, San } \\
\text { Pedro Marina } \\
\quad(3 \text { seq })\end{array}$} & Ratnagiri coast, India (2 seq) & [39] \\
\hline Polynoidae & $\begin{array}{l}\text { Paralepidonotus } \\
\text { ampulliferus }\end{array}$ & Philippines & New Zealand & & No GPS data (3 seq) & [40] \\
\hline Polynoidae & Subadyte pellucida ${ }^{(6)}$ & Croatia, Adriatic Sea & Red Sea & & Cádiz-Spain (2 seq) & [40] \\
\hline Sigalionidae & Pisione guanche & La Gomera, Spain & E Mediterranean & & Lanzarote, Spain (1 seq) & [39] \\
\hline Syllidae & Amblyosyllis speciosa $(7)$ & Misaki, Japan & USA Pacific & & & [40] \\
\hline Syllidae & Branchiosyllis exilis $(8)$ & Djibouti, Red Sea & Aegean Sea, USA Pacific & & Shark Bay, Western Australia (1 seq) & \\
\hline Syllidae & Eusyllis kupfferi & Madeira island, Portugal & E Mediterranean & & Kalbarry, Western Australia (1 seq) & [39] \\
\hline Syllidae & Syllis bella ${ }^{(9)}$ & $\begin{array}{c}\text { Laguna Beach, Pacific } \\
\text { USA }\end{array}$ & E Mediterranean & & Philipines (1 seq) & [39] \\
\hline Syllidae & Syllis gracilis $(10)$ & $\begin{array}{l}\text { Gulf of Naples, } \\
\text { Mediterranean Sea }\end{array}$ & Argentina & & $\begin{array}{c}\text { Peru (5 seq); Australia (2 seq); Los } \\
\text { Angeles, Pacific USA (12); } \\
\text { Phillipines (8 seq); Italy (2 seq); } \\
\text { Galicia, Spain (4 seq) }\end{array}$ & [40] \\
\hline Syllidae & Megasyllis nipponica & Sea of Japan & USA Pacific & & $\begin{array}{c}\text { Manazuru Peninsula, Pacific coast } \\
\text { of Japan (1 seq) }\end{array}$ & [40] \\
\hline
\end{tabular}

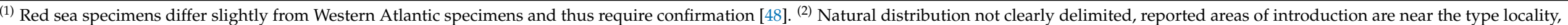

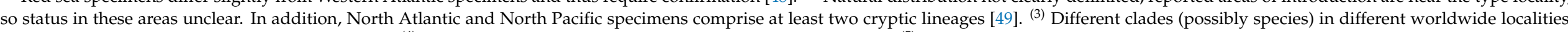

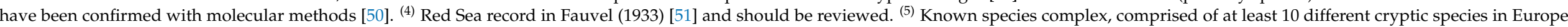

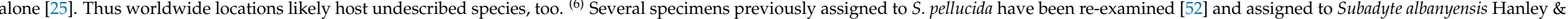

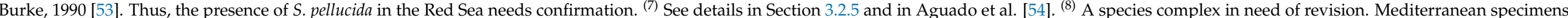

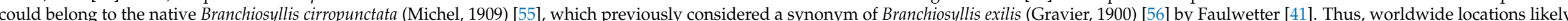

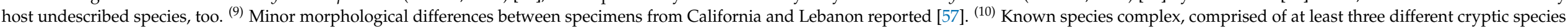
in the Mediterranean alone [58]. Thus, worldwide locations likely host undescribed species, too 


\subsection{Data Processing and Analyses}

We conducted a global gap-analysis by comparing the available barcoded species of Phyllodocida by 4 April 2020 and its congruence with the total number of valid species $[24,59,60]$. We compared the species list CL-MTVPP with all publicly available COI$5 \mathrm{P}$ sequence records using the BOLD checklist tool to obtain the percentage of barcoded species. We only included records identified at the species level and discarded those with tag codes added by BOLD users. Tag codes are often used either to distinguish lineages within cryptic complexes or between different populations in certain BOLD projects. As such, these records are considered as different species by the Checklist Progress Report (CPR) tool in BOLD. Thus, they will not match with the corresponding species found by the CPR tool (e.g., 'Nereis pelagica CMC01' will be considered a different species from 'Nereis pelagica').

All species in the dataset had a Barcode Index Number (BIN). We annotate them with one of four possible taxonomic congruency grades: Discordant (i.e., more than one nominal species assigned to the same BIN, which often include conflicts with sequences of species labelled with tag codes), complex (i.e., one nominal species assigned to more than one BIN), concordant (i.e., one species assigned to a single BIN), and singletons (nominal species with just one available sequence). We carefully inspected discordant BINs by checking their placement in neighboring-joining (NJ) phenograms, looking for valid species names, synonyms or contaminations, and by inspecting BINs' content on BOLD database. We considered BINs as "complex" when the same species had more than two sequences for at least two different BINs and were close to each other in the phylogenetic tree. Additionally, if the same species have two BINs with more than two sequences and a third BIN with one sequence, we would consider the third BIN as part of the complex as well, instead of a singleton. The BIN system clusters COI sequence data into molecular operational taxonomic units (MOTUs) independent of prior taxonomic assignment. As such, allows us confirming barcode sequence clusters vs. species designations concordance. We performed this validation by comparing the taxonomy on input records against all others in the same BINs, including those submitted and managed by other users [28].

We built the worldwide barcode map based on georeferenced data with the dggridR package in R (see Section 2.3 for details) and we used the BOLD Accumulation Curve tool to visualize the total number of sequences, species and BINs over time, for the whole order and for each family of Phyllodocida. We represented further data analyses by histogram and pie charts created with Microsoft Excel.

\subsection{Analyses at the Family Level}

The cumulative curve of accepted species along the temporal axis [61] for each selected taxon was calculated based on the year of description according to the WPD [6]. We have considered recent, currently accepted species names since the first species attributed to a given family. The information for each targeted family has been based on a selection (i.e., according to the authors criteria) of the respective most relevant references that are listed directly in the reference list.

\section{Results and Discussion}

\subsection{Species Diversity Trends among Phyllodocida}

Based on the data from the WPD (see Section 2.1. for details), the most species-rich family by far is Syllidae, with over 1100 currently accepted species, followed by Polynoidae, Nereididae, and Phyllodocidae (Figure 1a). In most families, about half of all described species names are currently considered accepted, though in some species the number of synonymized species names is considerably higher or lower (Figure 1b). The first species in what is today Phyllodocida was described in pre-Linnean times as Aphrodita aculeata Linnaeus, 1758 [62], previously known as Eruca echinata Barrelier, 1714 [63]. Since then, the number of described species has been growing at first slowly and more rapidly after the 
1860s, when several major works were published [64-67]. To date, there is no indication that the number of newly described species is slowing (Figure $2 a, b$ ).

a

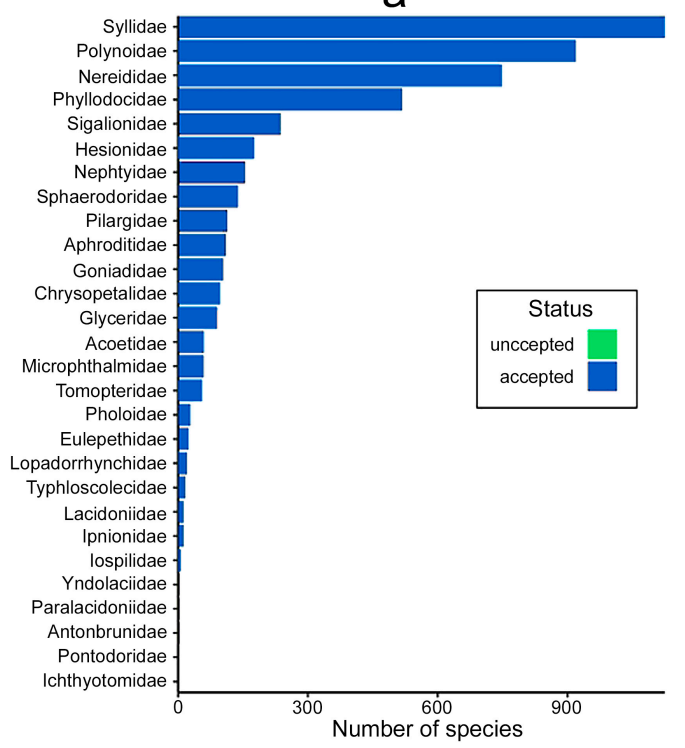

b

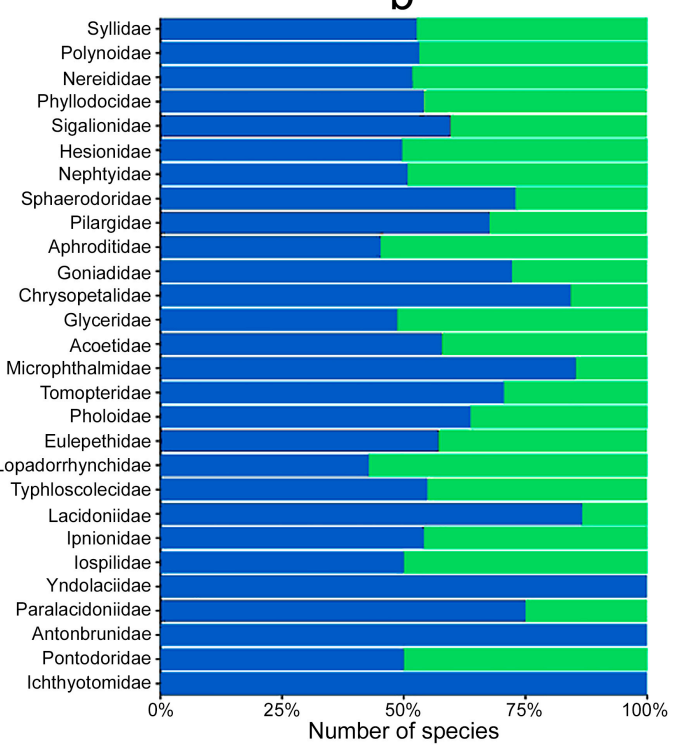

Figure 1. (a) The number of currently accepted species per family; (b) percent of accepted and unaccepted species names per family. Based on the WPD.
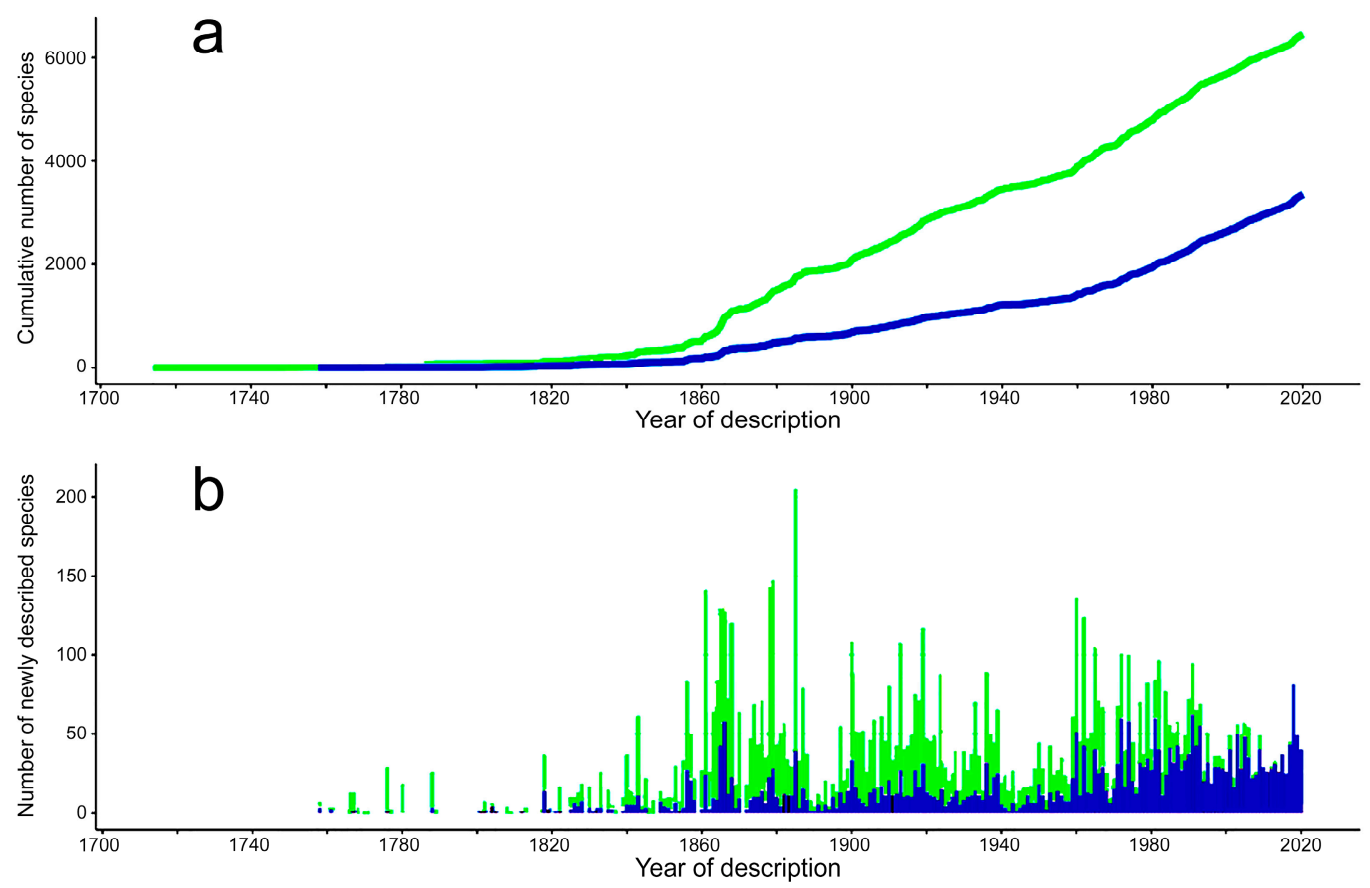

Figure 2. Description rates of species in Phyllodocida, based on the WPD. (a) Cumulative number of newly described species; (b) number of species described each year. Green: all species names including those currently unaccepted, blue: currently accepted species names.

\subsubsection{Biogeographic Distribution Patterns}

Phyllodocida are distributed globally, although the highest numbers of species have been reported from European, North American (especially the Gulf of Mexico), and Australian waters (Figure 3a). However, these numbers are biased by an increased sampling effort in these regions and do not reflect true species richness, as species richness was 
highly correlated with the number of records (Spearman's $\rho=0.737332, p \leq 0.001$ for hexagons, $\rho=0.6774194, p \leq 0.001$ for biogeographic regions). The five species with the most occurrence records were Nephtys hombergii (Savigny in Lamarck, 1818) [68], Hediste diversicolor (O.F. Müller, 1776) [69], Nephtys cirrhosa Ehlers, 1868 [65], Eteone longa (Fabricius, 1780) [70], and Goniada maculata Örsted, 1843 [71]. The five families with the most occurrence records were Nephtyidae, Phyllodocidae, Syllidae, Nereididae, and Polynoidae. The five species with the widest distribution (highest number of hexagon cells) were the holopelagic Pelagobia longicirrata Greeff, 1879 [72], Tomopteris septentrionalis Steenstrup, 1849 [73], and Typhloscolex muelleri Busch, 1851 [74], as well as the benthic Glycera capitata Örsted, 1843 [71] and Harmothoe imbricata (Linnaeus, 1767) [75]. The five taxa with the widest distribution were Phyllodocidae (including the holoplanktonic Alciopini), Polynoidae, Nereididae, Syllidae, and Lopadorrhynchidae.
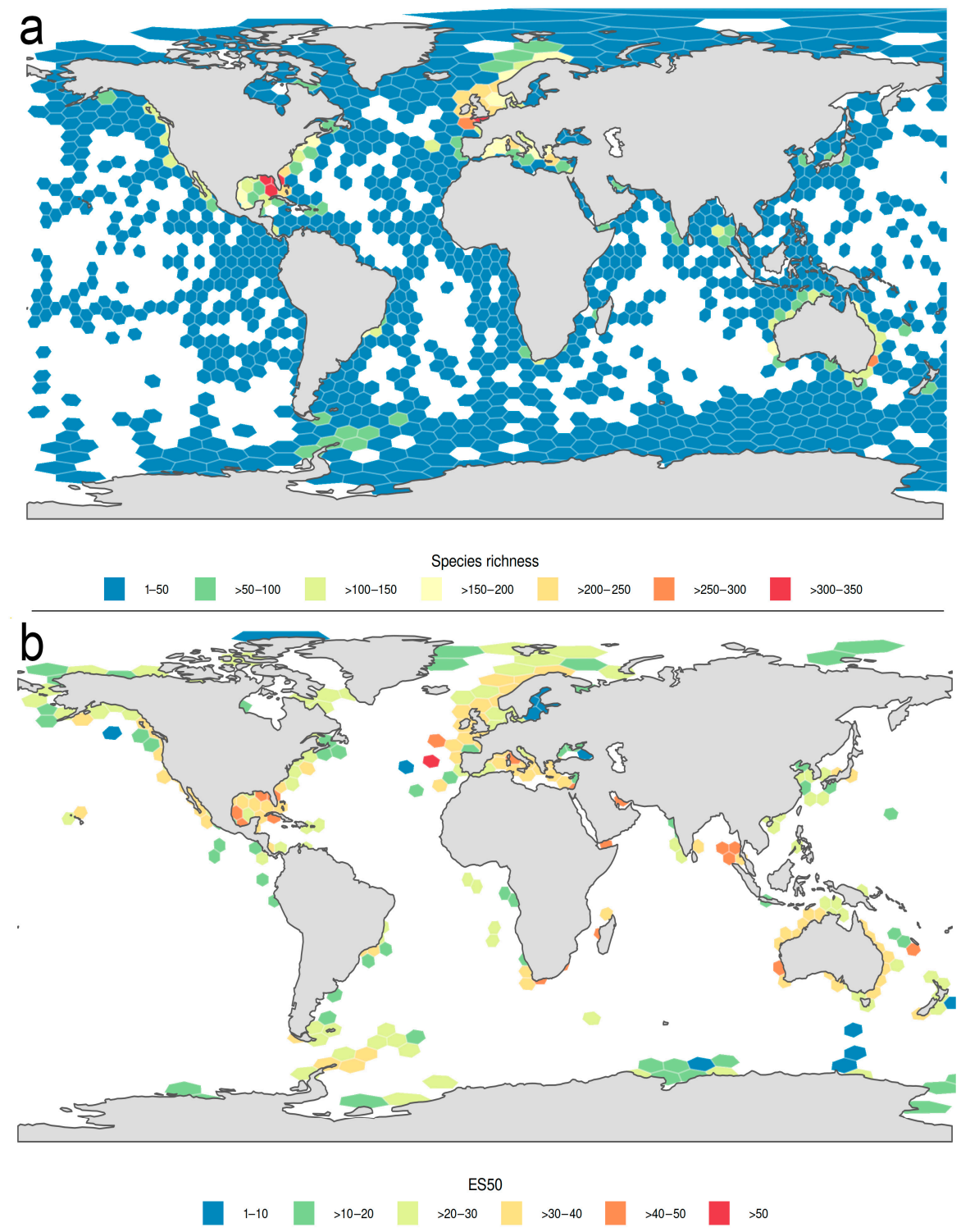

Figure 3. Global species richness of Phyllodocida. (a) The number of species; (b) expected number of species (ES50).

ES50 was slightly less biased than the number of species. While still showing the highest values in European, North American, and Australian coasts, those of South America and Antarctica also hosted a considerable diversity (Figure 3b). However, ES50 assumes sufficiently large sample sizes and the same sampling methods. In our analysis, many 
cells do not have a species number large enough for ES50 to be calculated, thus preventing acceptable estimates of the respective number of expected species. When analyzing larger biogeographic areas [36], the most species-rich were the Caribbean/Gulf of Mexico and the coasts of the Indian Ocean (Figure 4a). However, being large areas, sampling efforts were slightly more balanced and the ES50 gave what looked like a more accurate picture, with hotspots of species diversity in the Red Sea and the coastal Indian Ocean (Figure 4b).

Some biogeographic areas-notably Antarctica and the Pacific coasts of the America and Asia - had very unique species compositions, with $40-50 \%$ of endemism (i.e., species reported only from a given area). Similarly, circumtropical areas had a high number of unique species (with the exception of the offshore Indian and Pacific Ocean). Endemism was less frequent in the temperate areas of the Atlantic and the Arctic Oceans (Figure 4c). Latitudinal patterns of sampling effort appeared strongly biased towards the northern hemisphere (Figure 5a). However, raw species richness did not reflect this sampling bias, showing a secondary peak in the southern hemisphere (Figure 5b). ES50 appeared less biased, with lower numbers in temperate latitudes and several distinct peaks (Figure 5c). The number of occurrence records was correlated with the number of species (Spearman's $\rho=0.7413102, p \leq 0.001$ ) but not with ES50 (Spearman's $\rho=0.3011364, p \leq 0.08883$ ). The weak latitudinal gradient, with a rather uniformly high diversity across tropical and temperate latitudes and a drop of species richness only at extreme latitudes has been observed also in amphipods [76] as well as in a variety of other taxonomic groups [77,78].

The distribution patterns of Phyllodocida showed similarities to those found for polychaetes overall [79], which showed the highest species richness in the North Atlantic, Indonesia and Australia. These, plus the Mediterranean, Caribbean, and Red Sea and the Indian Ocean coasts, were also the regions where most species of Phyllodocida were expected (ES50). This may be in part due to correlation of the two datasets (as Phyllodocida form a large clade within Annelida). However, these trends have been identified by independent authors with a different methodology, thus supporting our results. Similarly, the bimodal latitudinal pattern we observed has been found not only for Annelida overall but seems to hold true for a variety of marine taxa $[77,80]$ and may be related to sea temperature $[79,80]$.

Regarding bathymetric patterns, the majority of the world's ocean are under-sampled, and the vast majority of information is available from the shallower coastal and surface areas [81], and Phyllodocida is no exception. Our results showed: (1) most records (i.e., $88.5 \%$ ) coming from 10 to $100 \mathrm{~m}$ depth (Figure 6a); (2) a similar distribution (although more balanced) for species number, which was correlated with sampling effort (Spearman's $\rho=0.964285, p \leq 0.002778$ ) (Figure 6b); and (3) ES50 not correlated with the number of records (Spearman's $\rho=0.2857143, p \leq 0.556$ ), being similar at all depths, except for the most extreme (i.e., very shallow and very deep) (Figure 6c). Although depth zones are not equally sized sampling areas and, thus, our results have to be interpreted with care, we are nevertheless showing that members of Phyllodocida seemed well adapted to live in deeper waters. However, in most depth zones half of the occurrence records belonged to less than five families, particularly to Polynoidae, while Nereididae, Syllidae, and Nephtyidae dominated in shallow waters (Figure 6d).

Our analysis also revealed that only 74 over the total number of species of Phyllodocida known to date have been reported as occurring non-natively in certain parts of the world. Most of them (i.e., >30) occur in Mediterranean waters, while in other coasts the number of non-native species is lower than 10 (Figure 7a). Interestingly, over half of the non-native species belong to Nereididae and Syllidae (Figure $7 \mathrm{~b}$ ). Although this would be expected given these families are among the most species rich, it seems that Polynoidae did not follow the same pattern and this is certainly something that merits further studies. As for barcoding, some non-native species of Phyllodocida listed in CL-MTAPP have been upload to BOLD indicating that they are considered invasive in certain areas (Table 1). However, the total number of barcoded alien Phyllodocida is relatively low (24, ca. 40\%) (Figure 7c, Table 1). 

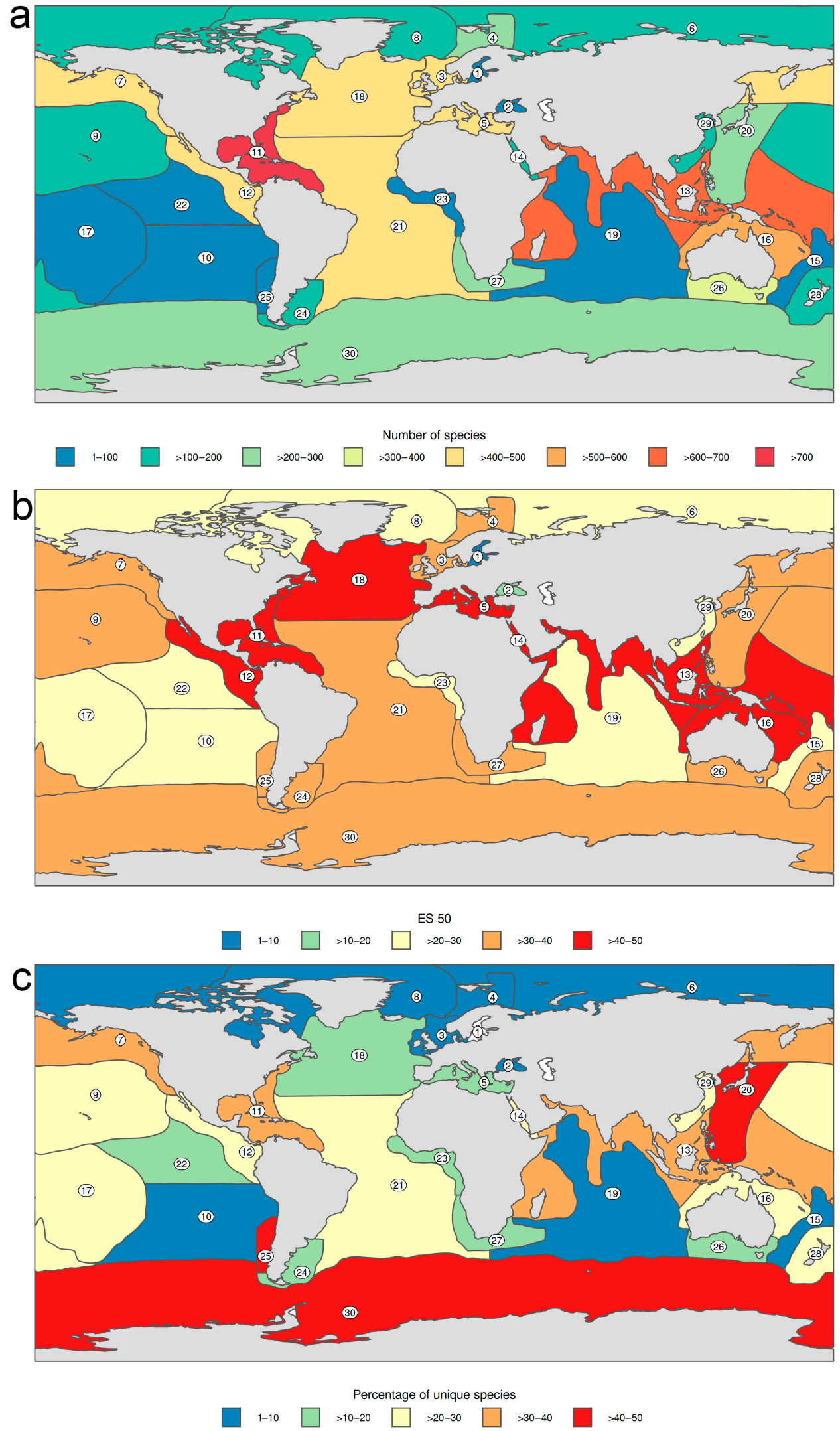

Figure 4. (a) The number of species per biogeographic region. (b) Expected number of species (ES50) per biogeographic region. (c) The percentage of species unique to each biogeographic region (as a proportion of the total number of species per region). Numbers in circles refer to the biogeographic region by Costello et al. [36]. 

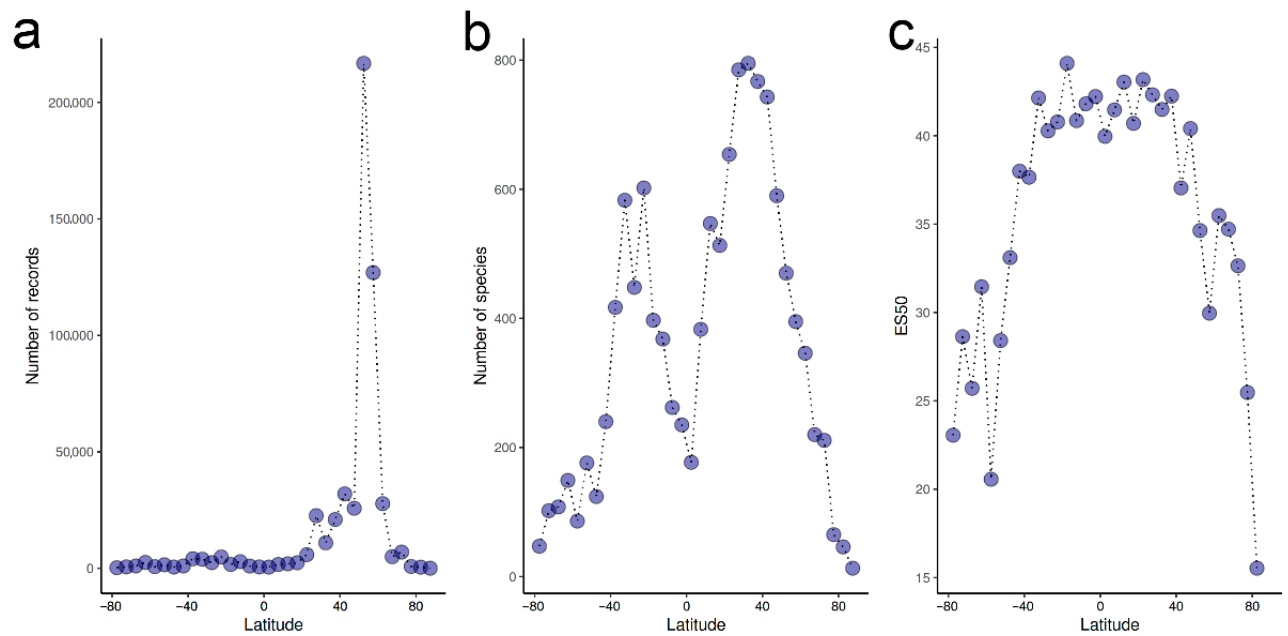

Figure 5. (a) The number of records, (b) number of species, and (c) expected number of species per $5^{\circ}$ latitude bands.
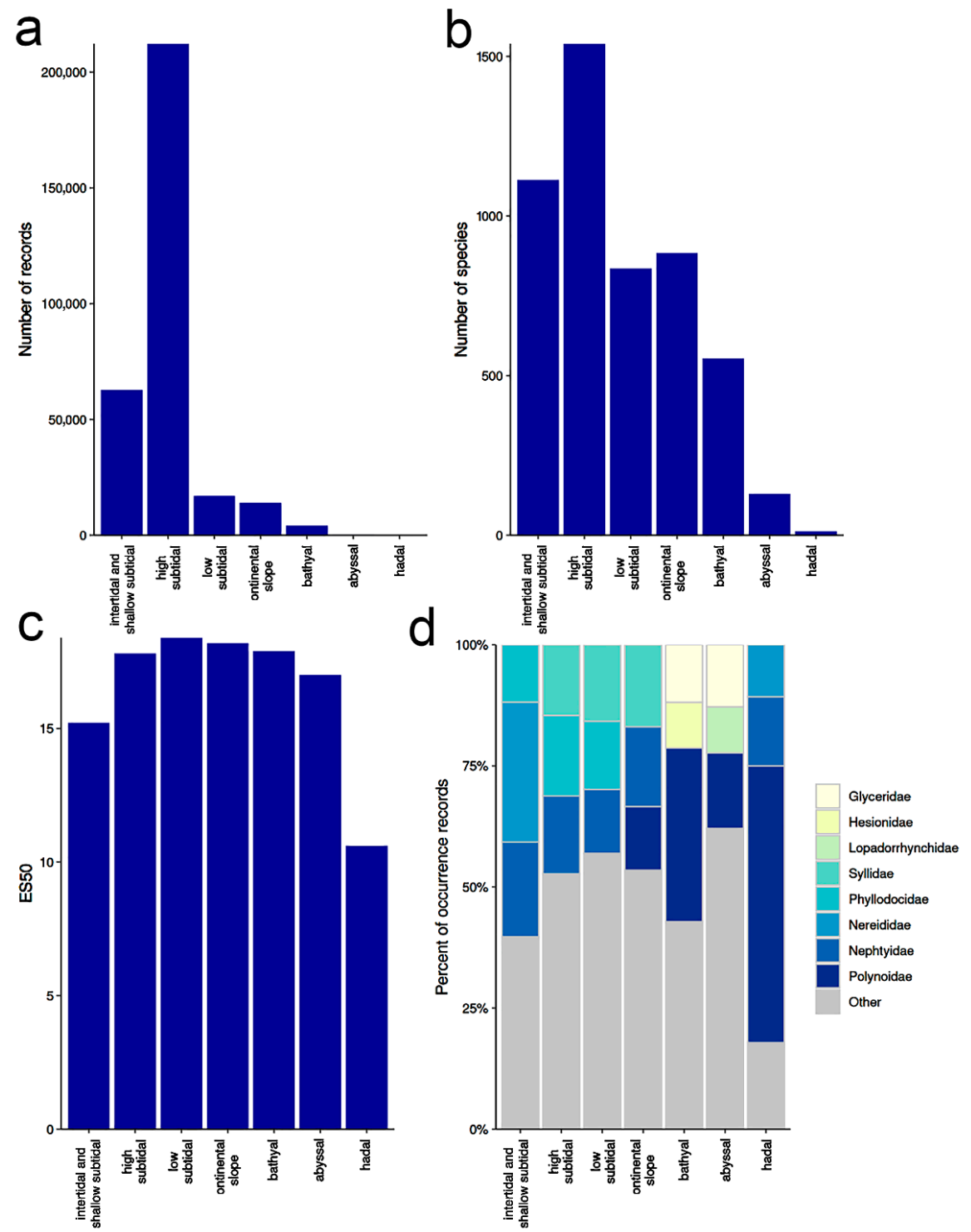

Figure 6. Depth distribution of Phyllodocida: (a) The number of records, (b) number of species, (c) ES50, and (d) the percentage of occurrence records per family and depth zone. 


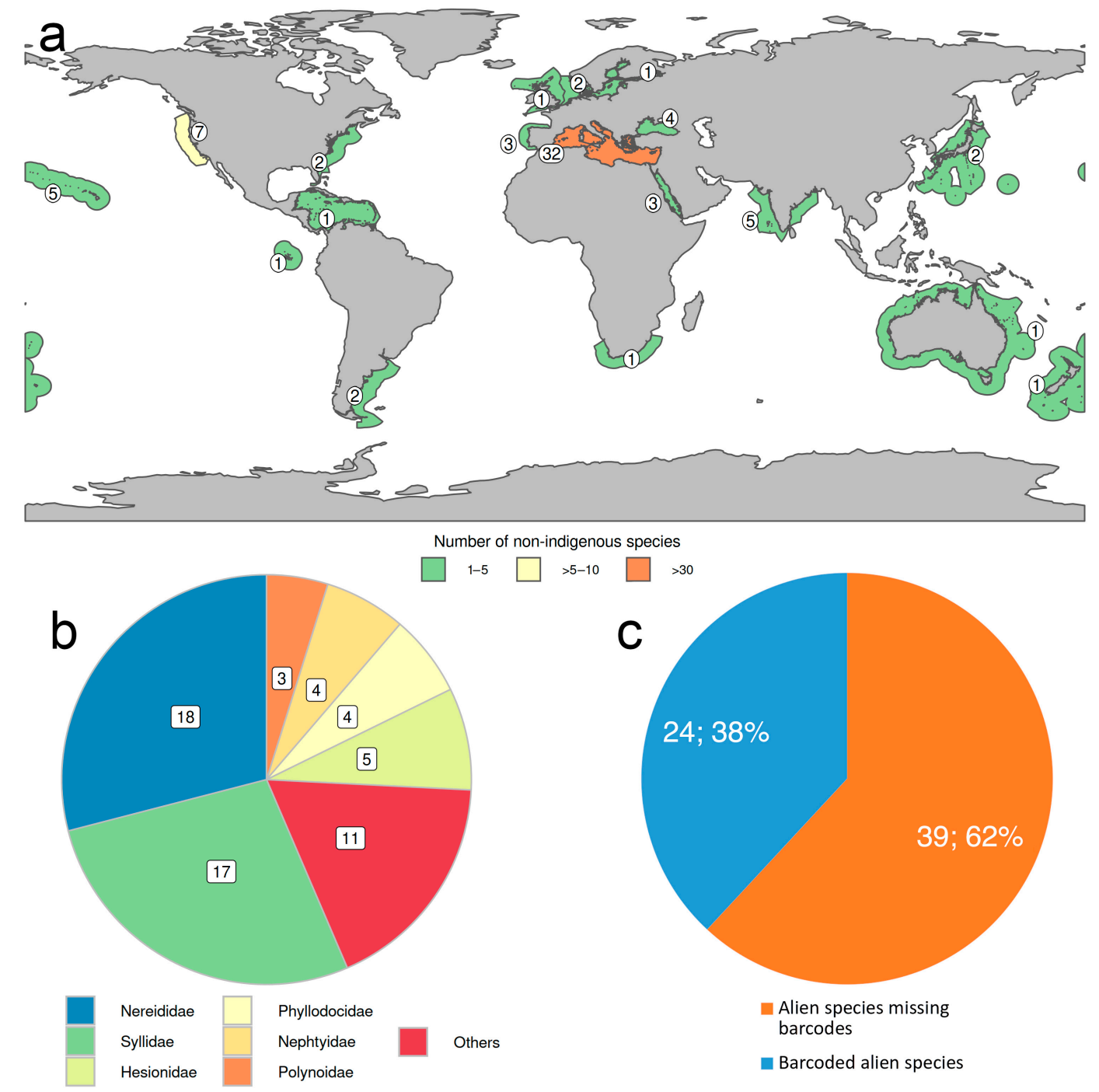

Figure 7. (a) The number of non-indigenous Phyllodocida species in various areas of the world. (b) Families with the most non-indigenous species, independent of region. (c) The number of barcoded species belonging to reported alien species found in literature.

As mentioned, much care must be paid to the information included in the databases, particularly concerning taxa identification. An example of how complex the situation can be, for instance, occurs with the report of Amblyosyllis speciosa Izuka, 1912 [82] from the USA (Table 1). The specimens of this species from Dorsey (California) were identified as part of Amblyosyllis hectori Aguado, Capa, Lago-Barcia et al., 2019 [54], while those from Washington in Pernet [83] belong to Amblyosyllis anae Aguado, Capa, Lago-Barcia et al., 2019 [54]. Amblyosyllis nigrolineata Okada, 1934 [84], which occurs in Japan, Australia, and California, was synonymized with A. speciosa [85] and later considered valid [54], while Amblyosyllis finmarchica (Malmgren, 1867) [86] occur in Norway, Russia, and Canada [54]. Therefore, the specimens reported from the USA could belong to one of four species, more likely A. nigrolineata, but certainly we may state that they do not belong to $A$. speciosa, as the species does not occur in the USA.

In addition, reports of alien species in the past were often not accompanied by detailed species descriptions-only molecular data - and many of these reports were propagated through publications and databases of non-indigenous species. While some of these species can be clearly identified as non-native or even invasive (even pests), many of them may in fact be undescribed species native to the area that simply constitute misidentifications. A good practice for publishing future reports of non-native species occurrences should, 
therefore, provide detailed taxonomic descriptions and barcoding data if possible. In addition, the specimen in question should be deposited in a reference collection for future consultation. Once barcodes of the species from the type locality or native area become available, these "aliens" can be assessed much more accurately.

\subsubsection{Global Gap-Analysis}

A total of 620 species of Phyllodocida have sequences published in BOLD, while the total number of BINS is 1215 (Figure 8a), with the most advanced libraries coming from North America. The relationship between sequences and BINs is caused by sequences being assigned to higher taxonomic ranks (genus or family), but also to wrong taxonomy assignment. In terms of number of sequences per family, Polynoidae took the largest share ( $24 \%)$, followed by Nereididae ( $20 \%)$, Phyllodocidae and Syllidae ( $11 \%$ each), Hesionidae $(10 \%)$, Nephtyidae and Glyceridae (4\% each), and only $2 \%$ are identified at order level only. All remaining families (except Nautiliniellidae-to date within Chrysopetalidaeand Pisionidae that are currently not accepted in WoRMS) [6] represent a 14\% (Figure 8b). However, Syllidae held the highest number of sequenced species (Figure 8c) and Polynoidae, Nereididae, Phyllodocidae, and Syllidae also appeared as the most afflicted with multiple BINs.

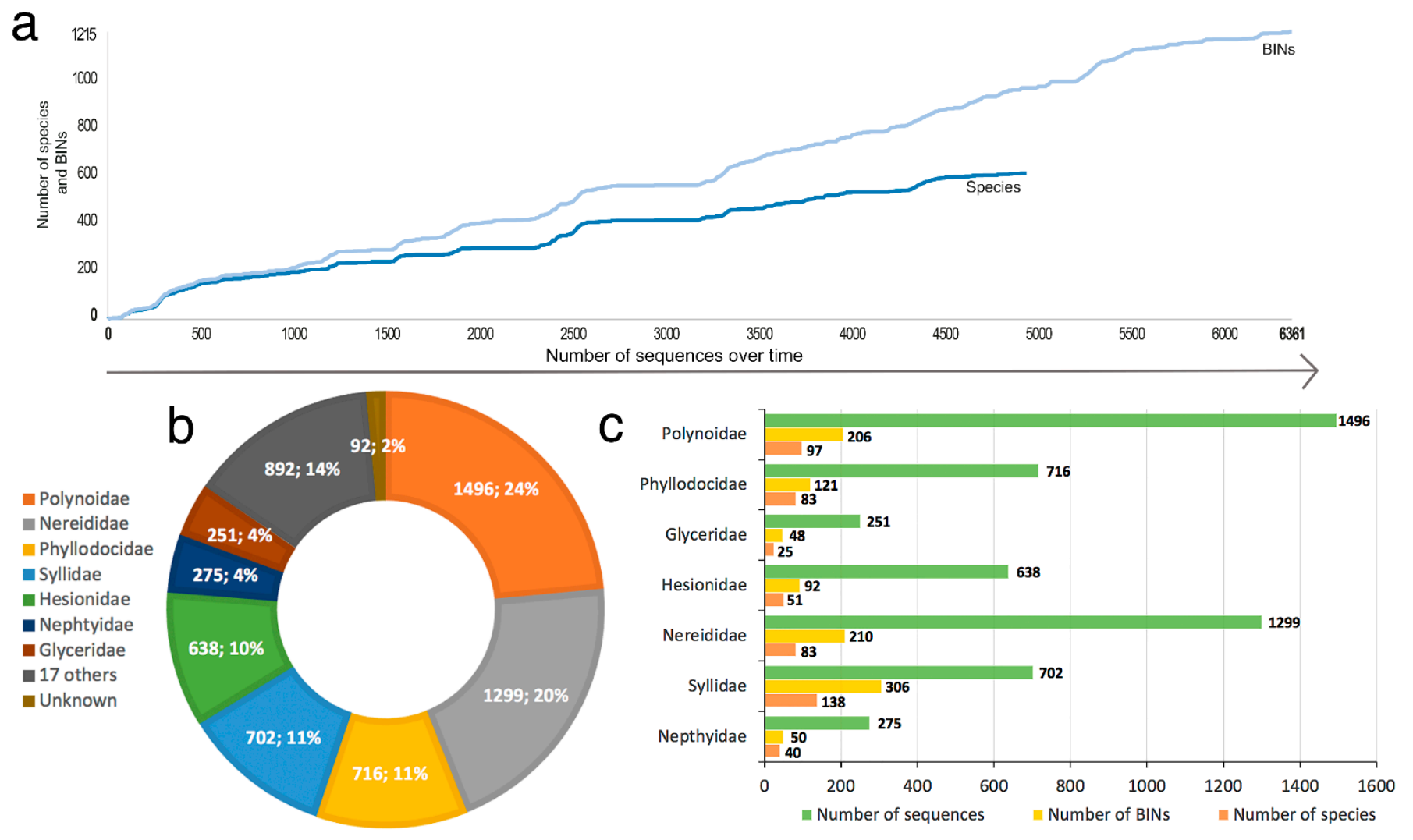

Figure 8. (a) Accumulation curve using all records from the dataset. The number of species and number of BINs by number of published/public sequences submitted to BOLD over time from 2008-2019. (b) The number of available sequences per family; records lacking family assignations (unknown) correspond to sequences only identified at the order level. (c) The number of species, BINs, and the total number of sequences for the most represented families.

The number of DNA barcodes assigned to different taxa levels among Phyllodocida was highly variable (Figure 9a), with 3787 (59.5\%) having species names, $754(11.9 \%)$ having only genus names, $559(8.8 \%)$ having family or subfamily names, and $94(1.4 \%)$ having just the order assigned. In turn, $1169(18.4 \%)$ barcodes had tag codes added to the species name. However, only 59.5\% over the total 6361 sequences found in BOLD had species 
names. Thus, only these records could be compared against the worldwide Phyllodocida species-level list (CL-MTAPP), which results in only $10.26 \%$ of the species (480) and $0.62 \%$ of the subspecies (1) from the species list having barcodes by April 4, 2020 (Figure 10a). Using the same approach, $32.63 \%$ (185) of the genera and 78.57\% (22) of the families were represented with DNA barcodes (Figure 10b,c). Overall, from the 6361 sequences, it was only possible to analyze 4917 barcodes, which imply that there are at least 1400 sequences misidentified and/or with invalid, misspelled, or synonymized names.

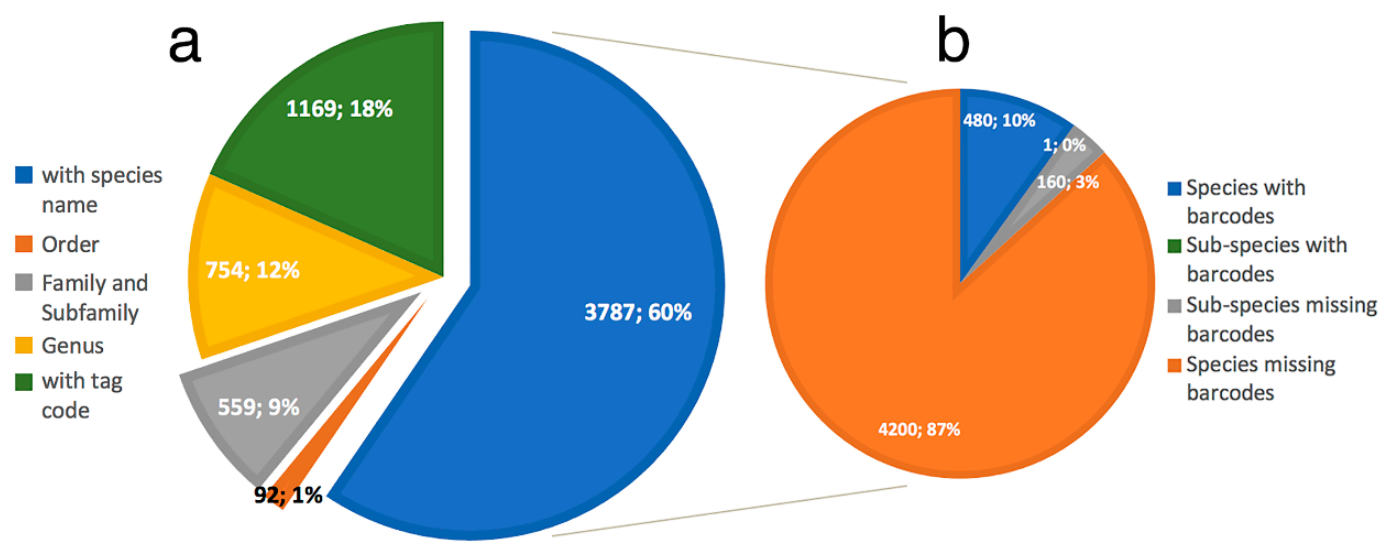

Figure 9. (a) The number of DNA barcodes with species names, barcodes identified only at the genus, family and subfamily, order and barcodes with tag codes added to the species name. (b) The number of barcoded records with species name present in the list of Phyllodocida (CL-MTAPP).
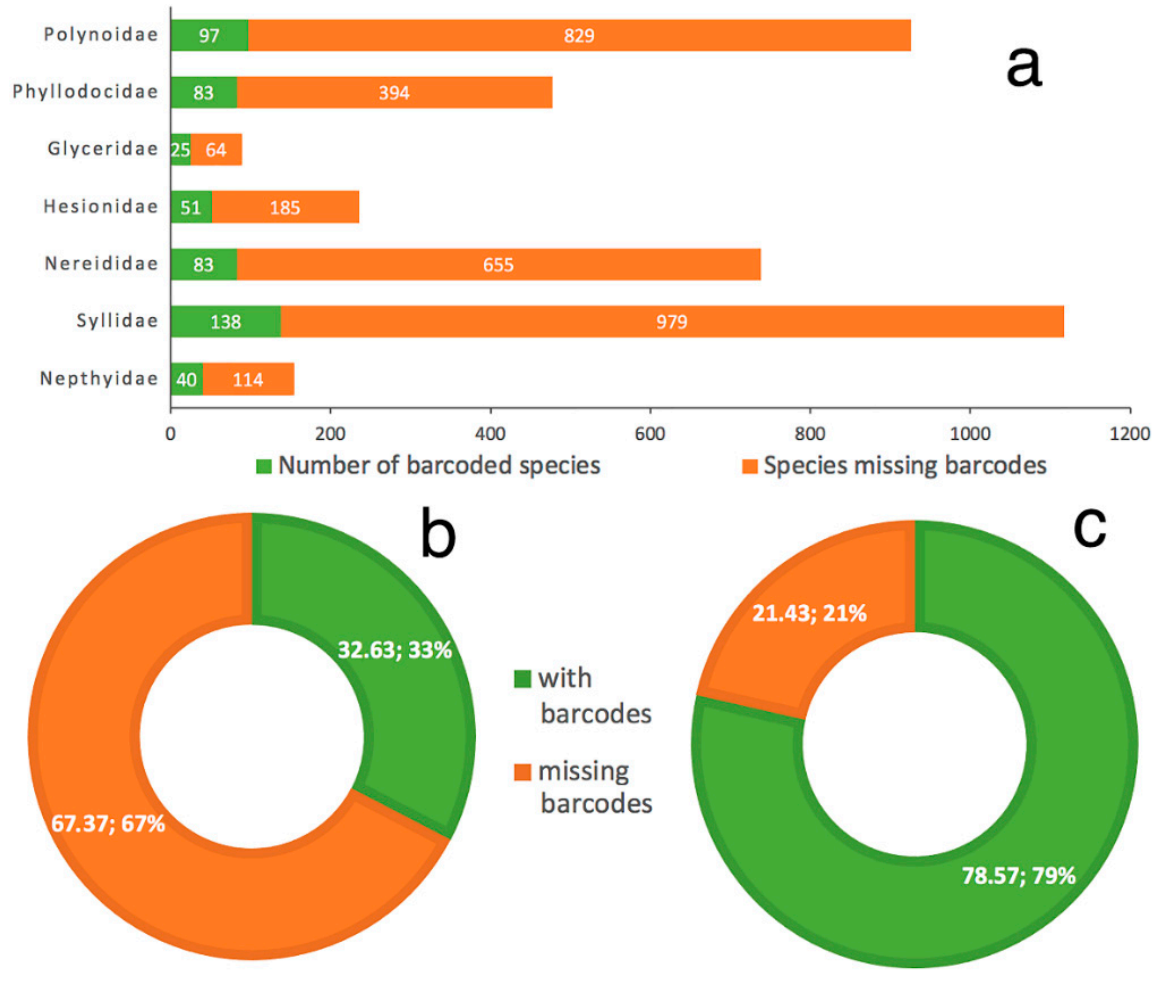

Figure 10. (a) The percentage of barcoded species and species still missing molecular data for the most represented families based on the list of Phyllodocida (CL-MTAPP). (b) The percentage of barcoded genera. (c) The percentage of families with DNA barcodes. Records identified only at the order were discarded. 
As mentioned above, Polynoidae and Nereididae had the highest number of representative sequences. However, at the same time they are also by far the families showing the lowest level of completion (Figure 10a, 10.5\% and 11.2\%, respectively). Conversely, Glyceridae and Nephtyidae doubled these numbers ( $28 \%$ and $26 \%$, respectively). When comparing the total number of barcoded species (527) among these families, Syllidae was the richest family, with $26.7 \%$ (138) of the sequenced species, while Glyceridae was the poorest $(4.8 \%, 25$ species). These data are still more informative and the lack of knowledge may be better assessed, if taking into account the extremely disparate number of valid taxa of these families: 1117 for Syllidae, 926 for Polynoidae, 736 for Nereididae, 89 for Glyceridae, and 154 for Nephtyidae [6].

As for the biogeographic distribution, although the total number of sequenced species in the DS-MTAPP dataset having georeferenced coordinates is certainly still very low (only 4145 records), barcoding in Phyllodocida showed similar biogeographic trends (Figure 11a) as those reported for the taxa and a similar bias. Most records came from North America (2382), followed by South East Asia (688) and Europe (484), there is also a considerable amount that have unspecific locations (358). As for the number of BINs (Figure 11b), from a total of $1215,34 \%$ (corresponding to 220 species) showed no apparent taxonomic conflict (i.e., concordant), while 6.7\% (81 species) showed taxonomic conflicts (i.e., discordant). Moreover, although $44.1 \%$ of the records (i.e., 500 ) were singletons (i.e., having just a single barcode), a significative number of them were identified only at the genus/family level or had tag codes. Thus, our analysis proved that there were only 257 species identified at the species level and having a single available sequence, while 35 "species" (15.2\% of the BINs) were possible cryptic complexes.

From the DS-MTBPP dataset (3509 barcodes from 277 species), only 1666 sequences were identified at the species level (and had no tag codes) allowing to analyze the respective bathymetric trends. Accordingly, barcoding appeared to be mostly available for shallow areas (Figure 6e), while deep-sea species showed a significantly low number of sequences after $100 \mathrm{~m}$ depth. Not only it is more costly to sample in such locations, but also it is often exceptionally hard to identify deep-sea specimens because of tissue degradation due to the combined effect of different environmental pressures and sampling techniques [19]. Indeed, most deep sea records of sequenced Phyllodocida, correctly identified at the species level, came from a few papers, e.g., [19,49], which certainly indicates that further efforts must be addressed in barcoding deep-sea members of the group. In addition, from the few species having specimens collected from significant different depth levels (more than $100 \mathrm{~m}$ apart), three showed again possible evidence of cryptic complexes with lineages specific to each depth layer: Phyllodoce madeirensis Langerhans, 1880 [87] (BINs: BOLD:AAZ1549, BOLD:AAZ0051 and BOLD:AAZ0052 at 246, 392 and $660 \mathrm{~m}$ depth, respectively); Glycera kerguelensis McIntosh, 1885 [88] (BINs: BOLD:AAA8690 and BOLD:AAA8688 at 5000 and 2000 $m$ depth, respectively) and Eunereis longissima (Johnston, 1840) [89] (BINs: BOLD:AAY3565 and BOLD:AAZ1159 at 300 and $700 \mathrm{~m}$ depth, respectively).

Indeed, there is a still unknown number of possible cryptic species complexes, which we have inferred, in part, from BINs and records having "tag codes" usually attributed by BOLD users to differentiate between cryptic lineages. For instance, "Nereis pelagica CMC01" and "Nereis pelagica CMC03", which display high COI intraspecific divergence appearing on different BINs. Over the last decade, cryptic species have been increasingly reported, thereby emerging as a substantial fraction of biodiversity and as a much more widespread and frequent phenomenon than previously thought, especially in marine invertebrates [18,90-93]. Dedicated studies about this topic can highly increase the representativeness of sequences belonging to these groups in genetic databases. Thirty-five species were considered possible cryptic species complexes, corresponding in total to 185 BINs. Some notorious examples are Platynereis bicanaliculata (Baird, 1863) [94] (six BINs), Treptopale homalos Watson, 2010 [95] (seven BINs) and Pseudonereis anomala Gravier, 1899 [96] (seven BINs). Syllis gracilis Grube, 1840 [97] (six BINs) was already a target study for cryptic diversity [98], with the authors refraining from naming the new species due to 
the existence of multiple lineages in the same type locality with no apparent morphological differences and inability to access the holotype for sequencing. An extreme case with a unique genetic fragmentation by presenting intraspecific divergence higher than usual compared to other annelids ( $>3 \%$ ) but still not enough to be considered different species for most cases $(<8 \%)[49,99]$, is that of Hediste diversicolor (O.F. Müller, 1776) [69]. It was already documented $[100,101]$ and in our study, we have found 37 BINS in 140 sequences. Hediste diversicolor, together with Hediste atoka Sato \& Nakashima, 2003 [102] (10 BINs in our analysis), seem to be outliers where the number of MOTUs clearly and far surpasses the number of possible species within the complex [103]. Overall, Polynoidae and Nereididae showed the highest number of representative sequences while having lower levels of completion (10.5\% and $11.2 \%$, respectively; Figure 10a), which might be underestimated due to possible hidden diversity. Integrative taxonomy is thus essential to solve this kind of situations and to allow naming the involved undescribed species. Otherwise, most molecular data providing enough support for species hypothesis [104] will continue to be unused, and large biodiversity sections would remain unnoticed [105].

The problem of cryptic species is, to some extent, intrinsically linked to the detection of exotic species. In some cases, supposedly non-indigenous or introduced species belonging to cryptic complexes. These complexes require detailed morphological studies, often combined with molecular data, to resolve the delimitation of the involved species, often leading to new species descriptions. Obviously, Phyllodocida is not an exception [54,58,90,106-108]. An obvious advantage of metabarcoding studies is the ability to easily detect invasive species in certain locations or even to report species in previously undocumented locations. However, a relatively low number (24, ca. $40 \%$ ) of Phyllodocida have been uploaded to BOLD with indications that they are considered invasive in certain areas (Table 1), while only two (i.e., only one syllid, one nereidid) have been sequenced in the location reported as being "invaded" (Figure 7c, Table 1). In some cases, the populations from the invaded area or nearby have different sequences in each of these areas, which also differ from that in type locality. This certainly raises the question whether these species are actually non-native or just overlooked cryptic complexes, which certainly merits further analyses.

To assess this and other complex taxonomic and biogeographic problems, recent tools, like the R-based application Barcode, Audit and Grade System (BAGS), may potentially be a valuable addition to forthcoming DNA metabarcoding studies, as it may long-term contribute to globally improve the quality and reliability of the public reference libraries. BAGS can quickly screen reference libraries to gauge data congruence and to facilitate the triage of ambiguous records for posterior review, allowing researchers to obtain the most useful and reliable data by highlighting and segregating records according to their congruency) [109]. Our analyses show the key importance of keeping libraries adequately curated, together with the need of adding metadata (e.g., GPS coordinates, depth) to public databases. This is especially critical as the library we have analyzed still has considerable gaps, numerous poorly represented species, and potential misidentifications or other errors in barcode generation. Certainly, this opens the door to future works that will allow to obtain a more precise picture of the biodiversity within Phyllodocida and, by extension, through the whole tree of life.

Even though the number of sequences and barcoded species have grown almost exponentially since 2008, our results highlight the apparent difficulty of having molecular data with correct identifications among Phyllodocida, with less than $60 \%$ of the records being usable to species-level in statistical analysis. Additionally, less than $11 \%$ of the compiled worldwide Phyllodocida list had barcodes. This might be partly justified by other factors, such as possible contaminations, misidentifications, outdated taxonomic identifications and synonyms. For example, two families in the BOLD dataset are now invalid [6]: Nautiliniellidae and Pisionidae, with the accepted names being Calamyzinae Hartmann-Schröder, 1971 [110] (subfamily for Chrysopetalidae Ehlers, 1864 [64]) and Sigalionidae Kinberg, 1856 [111], respectively, or the species Glycera tridactyla Schmarda, 1861 [112], identified as "Glycera convoluta", a subjective synonym, or the species Sphaerodoridium minutum (Webster 
\& Benedict, 1887) [113], being also identified as "Sphaerodoropsis minuta", a superseded subsequent combination. Indeed, less than $80 \%$ of the species were found barcoded in the list (i.e., 481 of 620), while there where 81 discordant BINs and 535 singletons (Figure 11b). The latter are subject to high uncertainty and low confidence due to the lack of comparable sequences and sources from multiple studies. Even if all species from the analyzed dataset could be found in the list, it still is a far cry compared to the current 4627 valid species of Phyllodocida [6]. This could be due to the marine biodiversity assessment challenge caused by the large-scale geographical sampling effort required, which can affect community richness outcomes [114]. However, the number of studies dedicated to this annelid group and, consequently, that of the associated barcoding projects must also be taken into account [24] For example, in the case of fishes, the amount of dedicated projects is significantly higher and, thus, the barcode library closer to completion [115-117], which is not the case for macroinvertebrate barcoding projects and the current state of its molecular libraries [60].

\subsection{Selected Taxa}

\subsubsection{Glyceriformia}

Glyceriformia Fauchald, 1977 [118] is a monophyletic clade within Phyllodocida that includes only Glyceridae Grube, 1850 [119] and Goniadidae Kinberg, 1865 [3,120]. All species are characteristically elongated, slender, cylindrical polychaetes that can reach considerable sizes up to $1 \mathrm{~m}$ long [121,122]. Their pointed, usually annulated prostomium with two pairs of terminal appendages, and their long, muscular, eversible axial proboscis, which is densely covered with papillae and provided with terminal jaws, are unique characters among Annelida [123].

Morphology based analyses confirmed the sister-group relationship of glycerids and goniadids and suggested a common ancestor with a few small and equal jaws and ciliated proboscidial papillae $[121,123]$. However, different molecular markers supported alternative hypotheses: sister-group relationship [124,125], monophyletic Glyceridae nested within a paraphyletic Goniadidae [124] or separated taxa [124,126]. The later indicates that the morphological similarities might be also the result of convergent evolution due to similar selection pressure, which is not very likely. However, both groups are distinguishable from each other, especially by the proboscidial armature (jaws and papillae) and the prostomial ciliation pattern [121-123,127,128].

Glyceriformia is one of the best investigated clades within Annelida as, in addition to two monographic reviews [121,122], there are many other dedicated papers dealing with special topics as well as with ultrastructural, phylogenetic and molecular aspects, which are summarized in the following paragraphs. Prior to the monographs, 165 glycerid and 111 goniadid species or subspecies (not counting fossil forms) and, afterwards, 12 additional species, had been described [124,129-136]. However, only 46 Glyceridae (40 Glycera Lamarck, 1818 [68], one Glycerella Arwidsson, 1899 [137], five Hemipodia Kinberg, 1865 [120]), and 64 Goniadidae taxa are currently accepted as valid (five Bathyglycinde Fauchald, 1972 [138], 12 Glycinde F. Müller, 1858 [139], 31 Goniada Audouin \& Milne Edwards, 1833 [140], six Goniadella Hartman, 1950 [141], five Goniadides Hartmann-Schröder, 1960 [142], three Goniadopsis Fauvel, 1928 [143], one Ophiogoniada Böggemann, 2005 [122], 1 Progoniada Hartman, 1965 [144]) [128]. The current state of the taxonomic diversity of the two families is perfectly reflected by the large disparity between all described taxa and valid taxa (i.e., 286 vs. 110). Overall, the increase of valid species descriptions within Glyceriformia has been slow and more or less constant, with a highest rhythm during the last years of the 18th century, a small but significant peak during the early 20th century and a markedly sharp peak at the beginning of the 21th century, with a maximum of seven in 2001 (Figure 12a-d).

Today the main diagnostic characters allowing to identify the typical species of Glyceridae (Figures 13a,b and 14a) and Goniadiae (Figure 13c,d and Figure 14b,c) are the chaetae, the jaw apparatus, the parapodia, and the proboscidial papillae, whereas, e.g., annulation, color, presence or absence of eyes are of little taxonomic use [121,122]. Scanning electron 
microscope studies demonstrated that the proboscidial papillae provide one of the most reliable characters for identification [121,122,145-148]. Attempts to use the finer structures of glycerid jaws failed due to intra-specific variation [149]. However, this might be the result of a misidentification [121]. Therefore, further scanning electron microscope examinations are needed to clarify the diagnostic value of glycerid jaws. This is less important to separate recent species, but it might be useful to increase the value of scolecodonts (jaws of fossil annelids) as index fossils for geology [123].

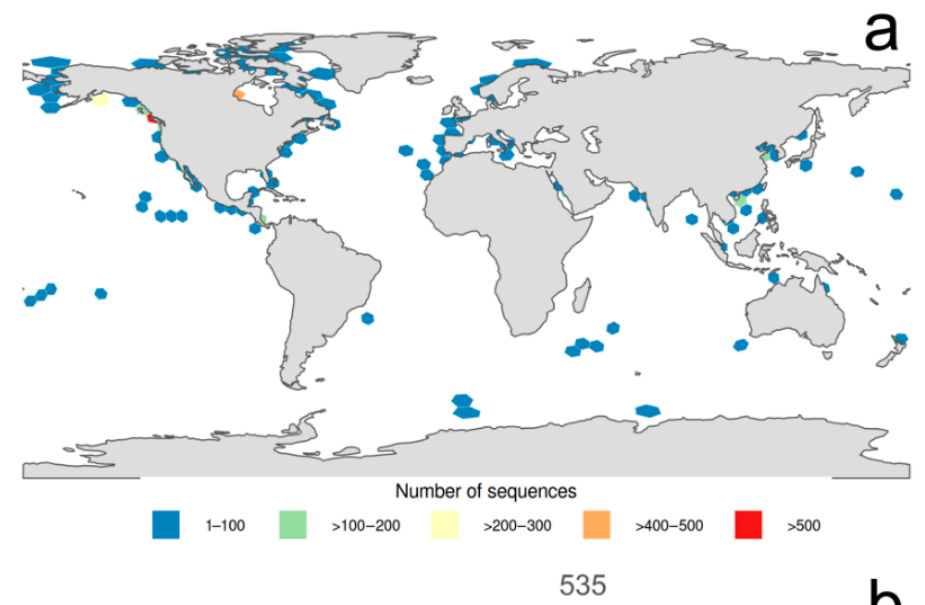

414

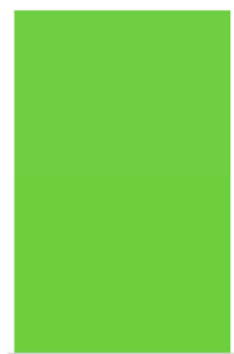

Concordant
Discordant

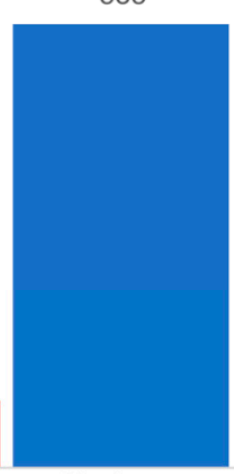

Singletons

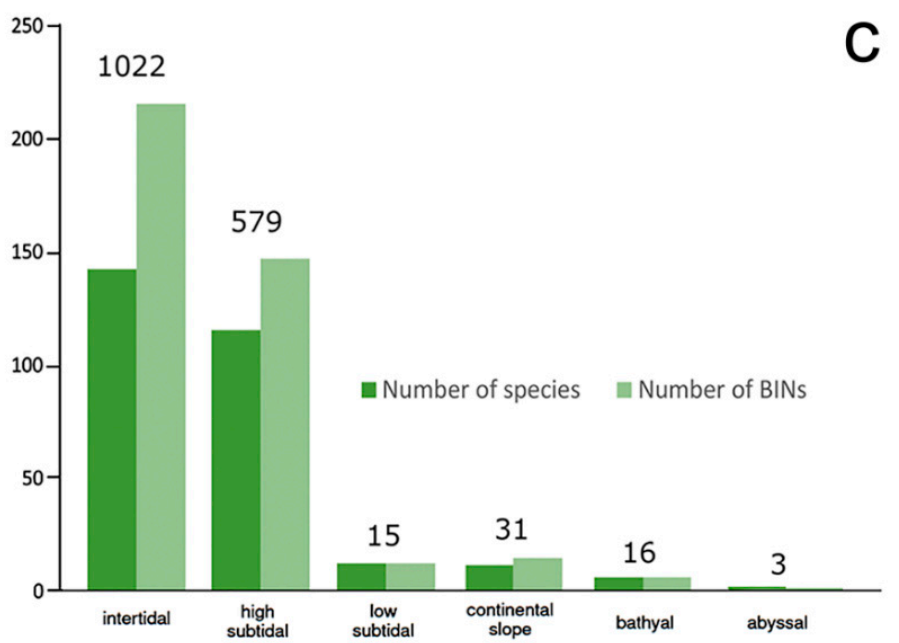

Figure 11. (a) Worldwide barcode distribution. (b) The number of barcode index numbers (BINs) according to congruency grades. Concordant: The number of BINs with no apparent taxonomic conflict; Discordant: taxonomic conflict within BINs; Singletons: BINs with just one single barcode record; Complex: one species assigned to more than one BIN. (c) The number of species with barcode and number of BINs-numbers on the top of each bar refer to the total number of sequences. 

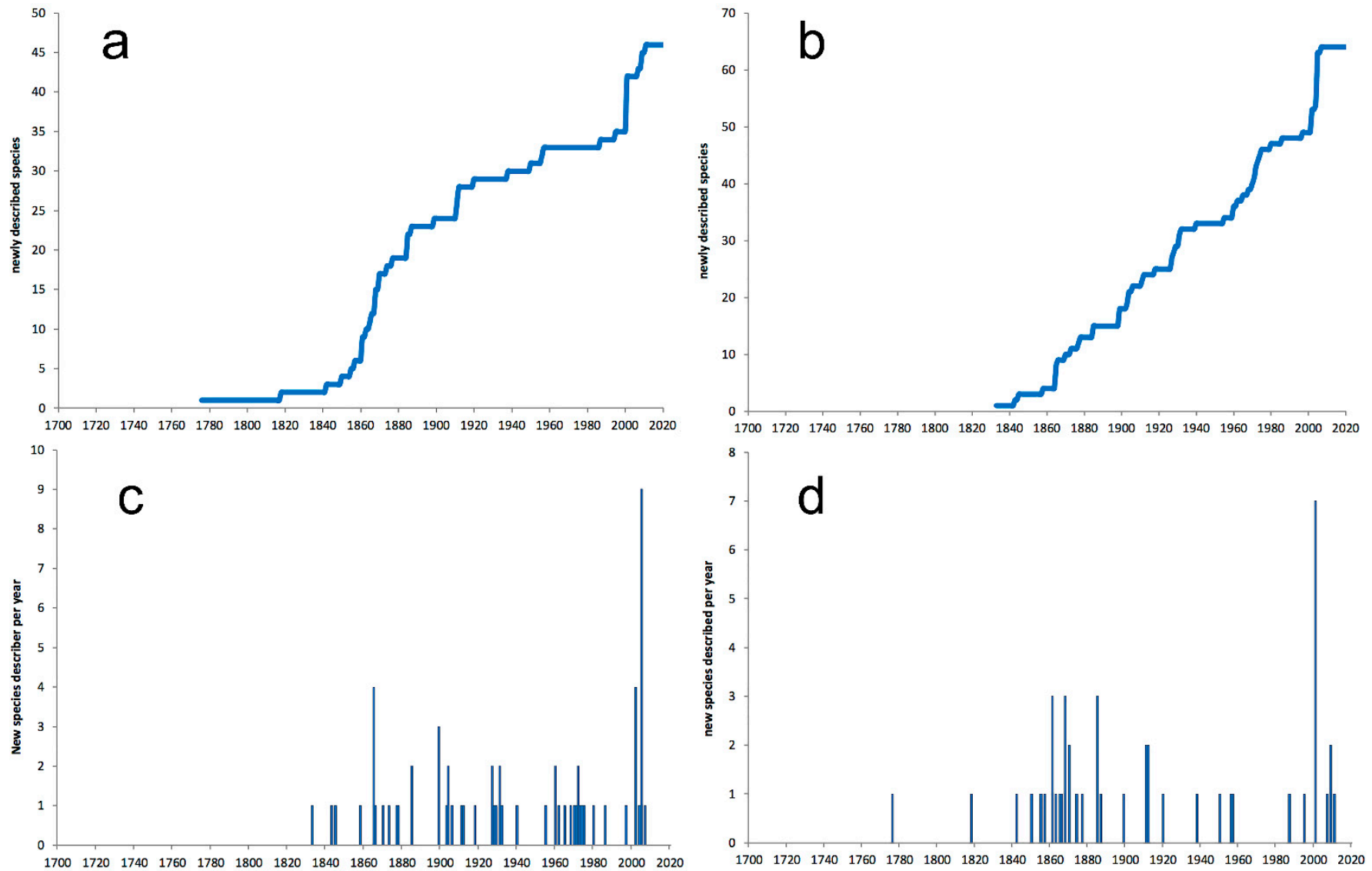

Figure 12. Cumulative curve of newly described species through time $(\mathbf{a}, \mathbf{c})$ and number of new species described per year (b,d) in Glyceriformia. (a,b) Glyceridae, and (c,d) Goniadidae.

Armed with a powerful, eversible proboscis, glycerids (Figure 13a,b and Figure 14a) and goniadids (Figure 13c,d and Figure 14b,c) are important but usually not very abundant benthic predators. They are common burrowers in soft and sandy bottom sediments, forming complex semi-permanent burrow systems with a series of openings [150] or being motile [134,151-153]. Glyceriformia themselves are predated by some birds [154], as well as benthic fishes and crustaceans [155-162]. Furthermore, larger species of glycerids are used as fish bait for sport and commercial fisheries [152,154,163-170].

Glyceriformia have a worldwide distribution from intertidal to abyssal depths [121,122,124]. Glycerids are even present in extreme environments like hydrothermal vents [171,172] and cold seeps [134]. Widespread taxa were very common among polychaetes before using molecular data in species delineation, and some Glyceriformia were even regarded as cosmopolitan [121,122]. Therefore, detecting a complex of cryptic species using two molecular markers was not a surprise [173]. These species supposedly being morphologically "identical" were only investigated via light microscopy and obviously belonged to different taxa [174]. Genetic cryptic species are of course also possible within Glyceriformia $[92,124,175]$, while previous research also confirmed widespread distributions of some deep-sea taxa [174]. The distribution patterns of these species demonstrated that some taxa have a high dispersal capability and show an extended level of eurybathy, whereas other species are restricted to the deep sea. Nevertheless, the underlying processes to become cosmopolitan are unknown. 


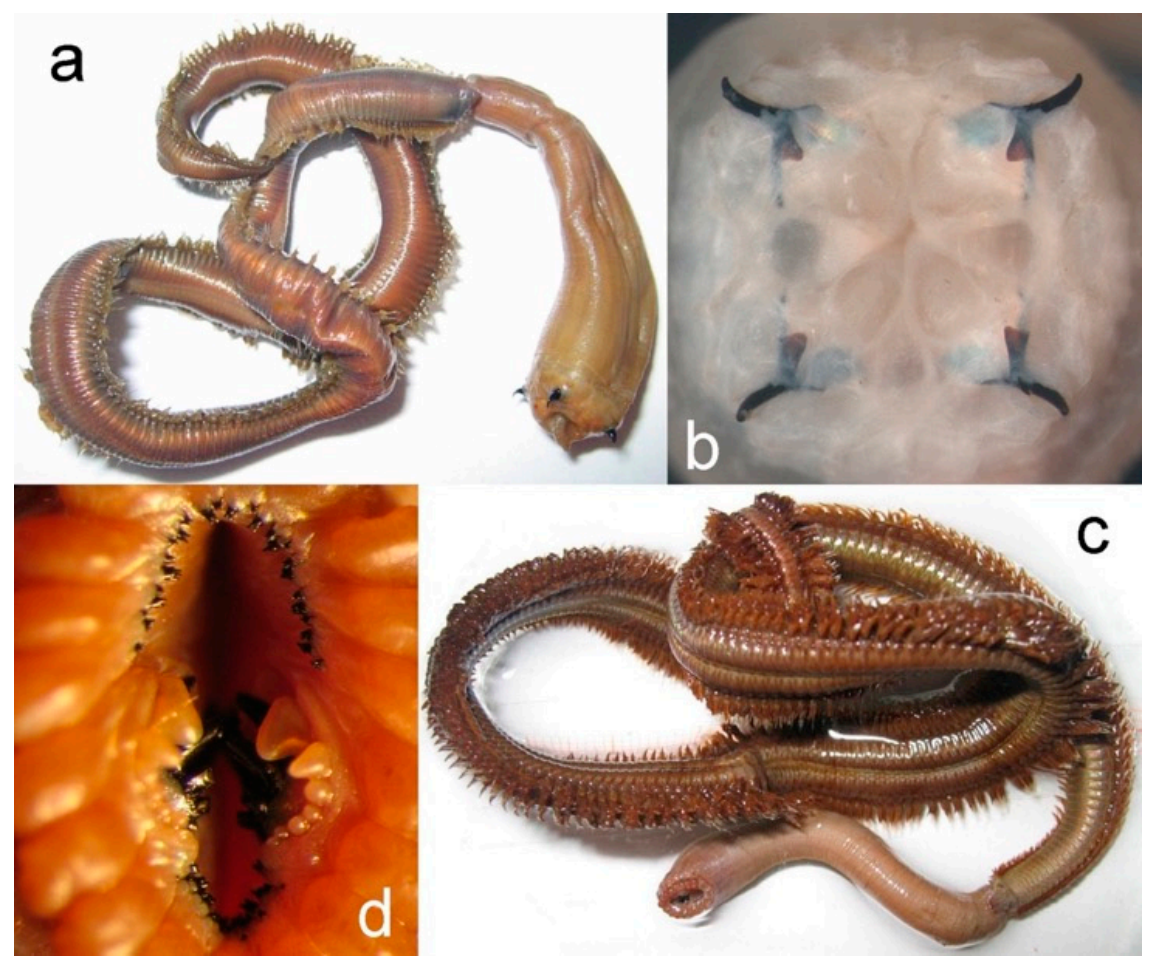

Figure 13. (a) An example of an entire preserved specimen of Glycera (Glyceridae), with fully everted pharynx; (b) detail of the buccal armature in an everted pharynx of Glycera; (c) an example of an entire preserved specimen of Goniada (Goniadidae), with fully everted pharynx; and (d) detail of the buccal armature in an everted pharynx of Goniada.
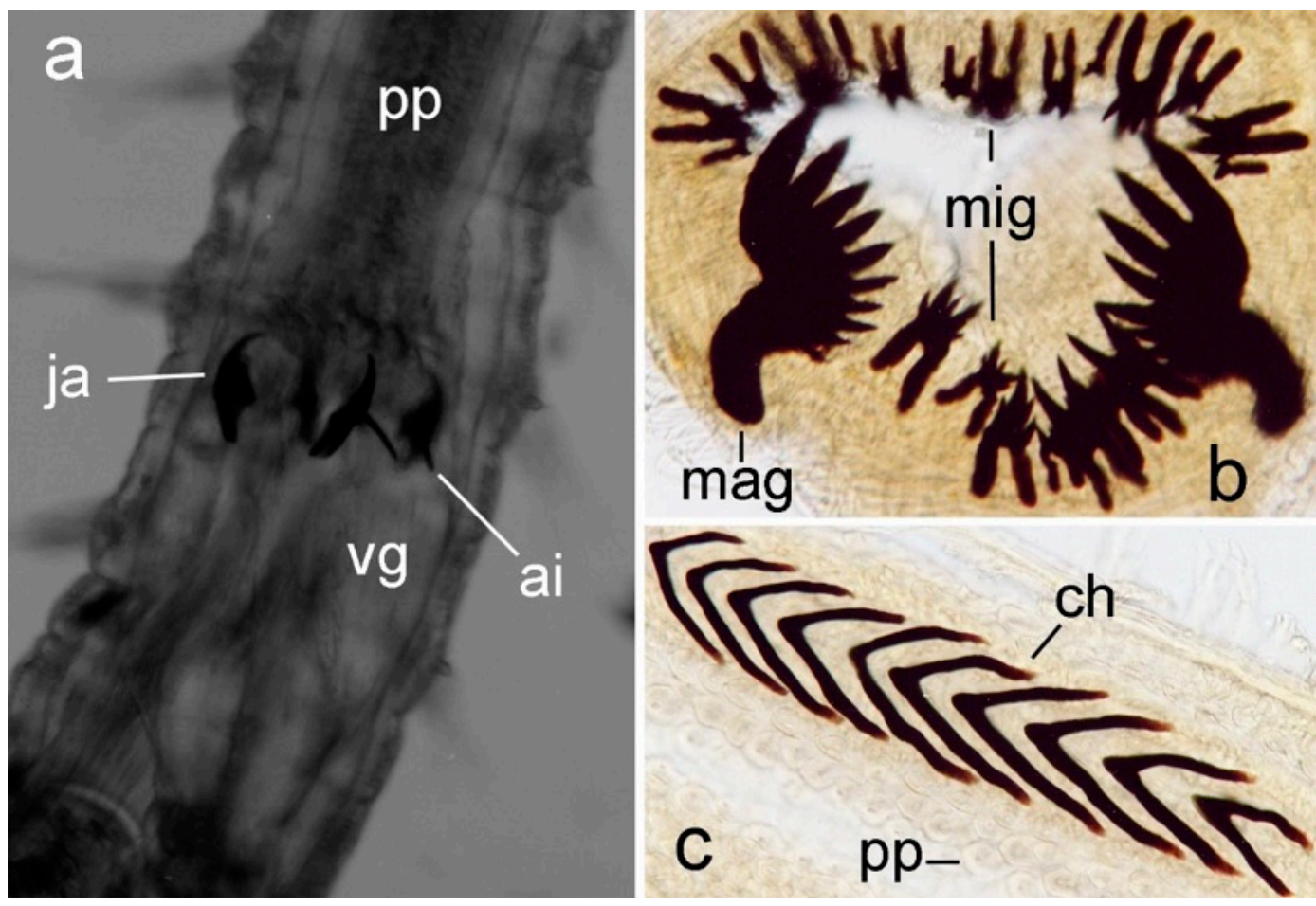

Figure 14. (a) Glycera sp. (Glyceridae), part of a retracted anterior gut; ai: aileron; ja: jaw; pp: proboscidial papillae; vg: venom gland; (b) Goniada sp. (Goniadidae), ring of macro- (mag) and micrognaths (mig). (c) Part of the proboscis with chevrons (ch) and proboscidial papillae (pp). 
Concerning predominate acceptance, passive transport by bottom ocean currents is the main factor for the dispersal $[176,177]$, whereas own studies suggested surface currents as the main driving factor $[124,174,178]$. There is evidence to support this alternative hypothesis. For example, the glycerid Glycera capitata has planktotrophic larvae [179] with a fairly long pelagic larval duration. Not surprisingly, it was present in all investigated basins of the South Atlantic and Southern Ocean, showing almost identical (99-100\%) mitochondrial (COI, 16S) and nuclear DNA sequences (18S, ITS 1 + 2). By contrast, the goniadid Progoniada regularis Hartman, 1965 [144], has lecithotrophic planktonic larvae [179], which have yolk that must settle before depleting their food source. Species like P. regularis are also present in all investigated areas, but populations from different basins show a higher diversity in terms of gene markers (COI, ITS1, ITS2). Molecular analyses at population level revealed an interesting distribution pattern. Those from Northern Brazil and Southern Angola Basins were nearly identical and separated from those of Argentine, Southern Brazil, Guinea, and Cape Basin. This distribution cannot be explained by deep-water currents in this area [180]. Conversely, a presumed influence by surface or subsurface currents [181] makes much more sense. However, these studies were limited in scope as they were based on only a few specimens from each locality and the question still merits further efforts.

Large ocean basins are some of the least explored parts of the world and we know almost nothing about their inhabitants such as benthic animals [182]. For a long time, these areas were postulated to be only muddy deserts, but they revealed to be great reservoirs of biodiversity $[183,184]$ with strong connections to the surface $[185,186]$. To assess their real biodiversity, extensive and well-preserved material for morphological and molecular studies is needed. The combination of classical taxonomic techniques with modern aspects of biodiversity research allows the analysis of factors influencing the distribution and migration of species as well as the investigation of the background of biogeographic zonation. Furthermore, the results will be useful to clarify the phylogenetic relationships within Glyceriformia and to determinate their position within Phyllodocida. However, the "well"-known shelf and coastal areas have to be newly investigated to identify for example alien species, species complexes, and cryptic or sibling species, and to gain knowledge about changes in biodiversity due to climate change and increasing human activity.

\subsubsection{Holoplanktonic Taxa}

Many holoplanktonic polychaetes (i.e., those completing the entire life cycle in the plankton) were considered as aberrant [2,187-189]. Their phylogenetic relationships have been largely discussed [188-193] and their taxonomy still remains complex and controversial. In fact, the holoplanktonic species have either been grouped as minor taxa within Phyllodocidae $[3,189,192,194-196]$ or as independent families within Phyllodocida [64,119,188,191,197-201]. Even at the phylogenomics' age, the holoplanktonic polychaetes are still enigmatic, poorly known and with uncertain phylogenetic relationships, thus requiring further research to advance in their knowledge. Nevertheless, the currently accepted situation includes Poeobiidae (including Poeobius Heath, 1930 [202]) and Flotidae (including Flota Hartman, 1967 [203] but now synonymized with Flabelligeridae by Osborn [204]) being related to Terebellida and all other holoplanktonic families being related within Phyllodocida [205,206]. The latter, the subject of this paper, are Alciopini Ehlers, 1864 [64], Iospilidae Bergström, 1914 [190], Lopadorrhynchidae Claparède, 1868 [66], Pontodoridae Bergström, 1914 [190], Tomopteridae Grube, 1850 [119], Typhloscolecidae Uljanin, 1878 [207], and Yndolaciidae Støp-Bowitz,1987 [193] (Figure 15a-f). 


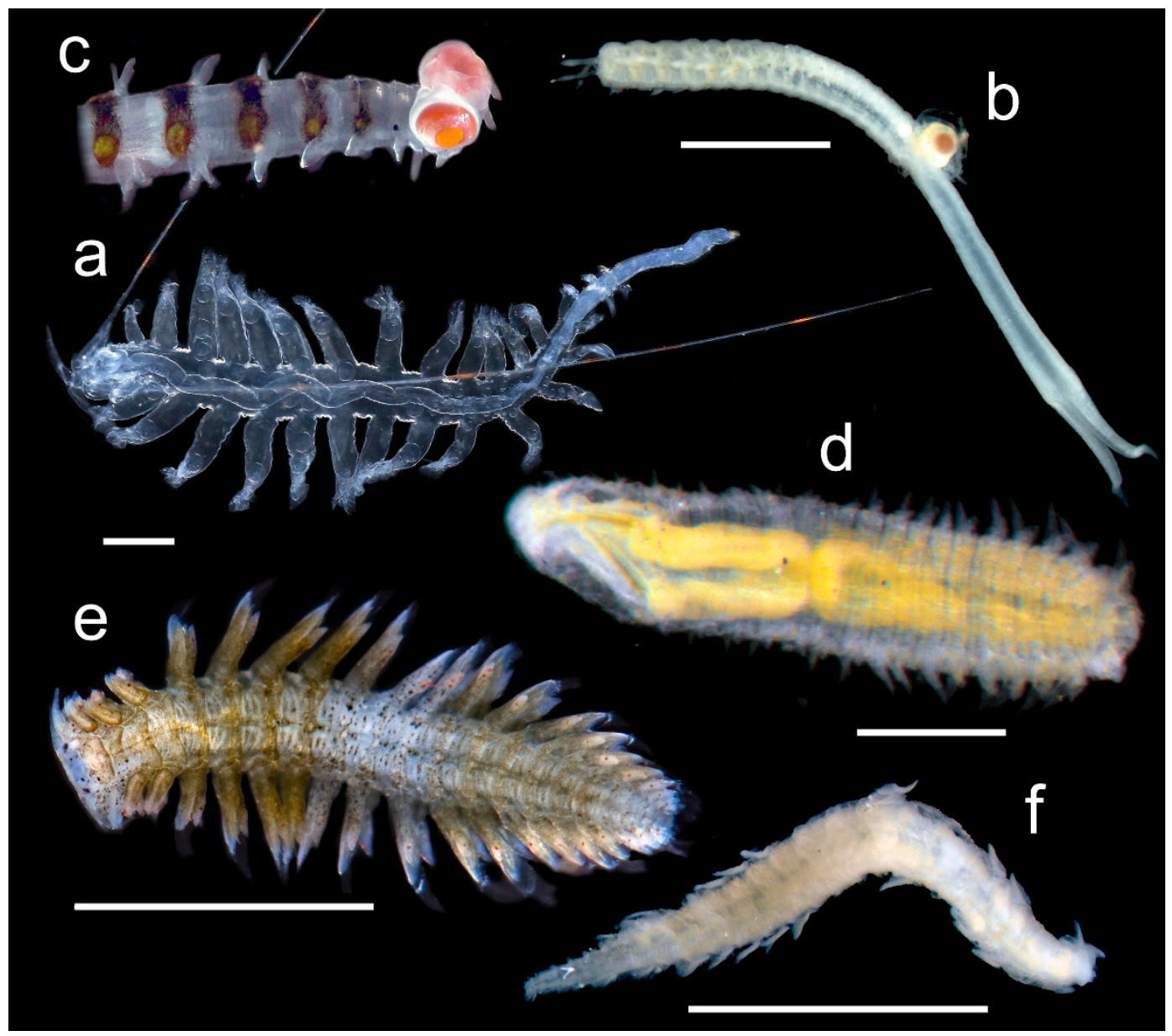

Figure 15. Examples of holoplanktonic Phyllodocida. (a) Tomopteridae: Living Tomopteris sp.; (b,c) Alciopini: (b) preserved Vanadis sp.; (c) detail of the anterior end of a living Vanadis sp; (d) Iospilidae: preserved Phalacrophorus sp.; (e) Lopadorrhynchidae: living Lopadorrhynchus sp.; (f) Typhloscolecidae: Typhloscolex sp.; scale bars are $1 \mathrm{~mm}$. Images from Gabriel Monteiro, provided by ColBIO-IOUSP $(\mathbf{b}, \mathbf{d}, \mathbf{f})$ and Xavi Salvador Costa $(\mathbf{a}, \mathbf{c}, \mathbf{e})$.

Holoplanktonic polychaetes are relatively less diverse than their benthic relatives, from which they can be clearly distinguished by specific adaptations and distinctive morphophysiological traits. All of them are assumed to be derived from benthic ancestors, even though there is no real evidence supporting this hypothesis [2]. Their relative simplification more likely resulted from an adaptation to a pelagic mode of life, pointing on a basallybranching position. Alternatively, it was hypothesized that "pelagic groups could have given rise to other pelagic groups. And even if their sister taxa are benthic, they could have members which, secondarily, have returned to a benthic life" [194]. In this sense, it is important to consider that, although rare, there are fossil records of pelagic polychaetes assigned to Tomopteridae dating back to the Lower Carboniferous [208,209].

Most species were described in the last part of the 19th century and the first half of the twentieth century, with very few posterior new species, e.g., [193,210-212] (Figure 16a,b). All synonymies and the main systematic information are listed in Dales [213] and Dales and Peter [214]. Currently there are around 143 nominal species within Phyllodocida. Among them, 12 nominal genera and approximately 49 species, most of them belonging to Rhynchonereella Costa, 1864 [215] and Vanadis Claparède, 1870 [67], are included within Alciopini. Among Iospilidae, there are currently five nominal species included in three genera: Iospilus Viguier, 1886 [216], Paraiospilus Viguier, 1911 [217], and Phalacrophorus Greeff, 1879 [72,218,219]. The first described species of Lopadorrhynchidae was Lopadorrhynchus brevis Grube, 1855 [220], which was included within Phyllodocidae [119,220]. 
Since then, only six nominal genera have been described, one of them very recently, Bathypelagobia Kolbasova in [218]. They include 21 species, most of them within Lopadorrhynchus Grube, 1855 [220] and Maupasia Viguier, 1886 [216]. Pontodoridae, in turn, only includes Pontodora Greeff, 1879 [72], with Pontodora pelagica Greeff, 1879 [72]. Epitoka pelagica Treadwell, 1943 [221], initially placed within Syllidae, was considered a junior synonym of $P$. pelagica [189].
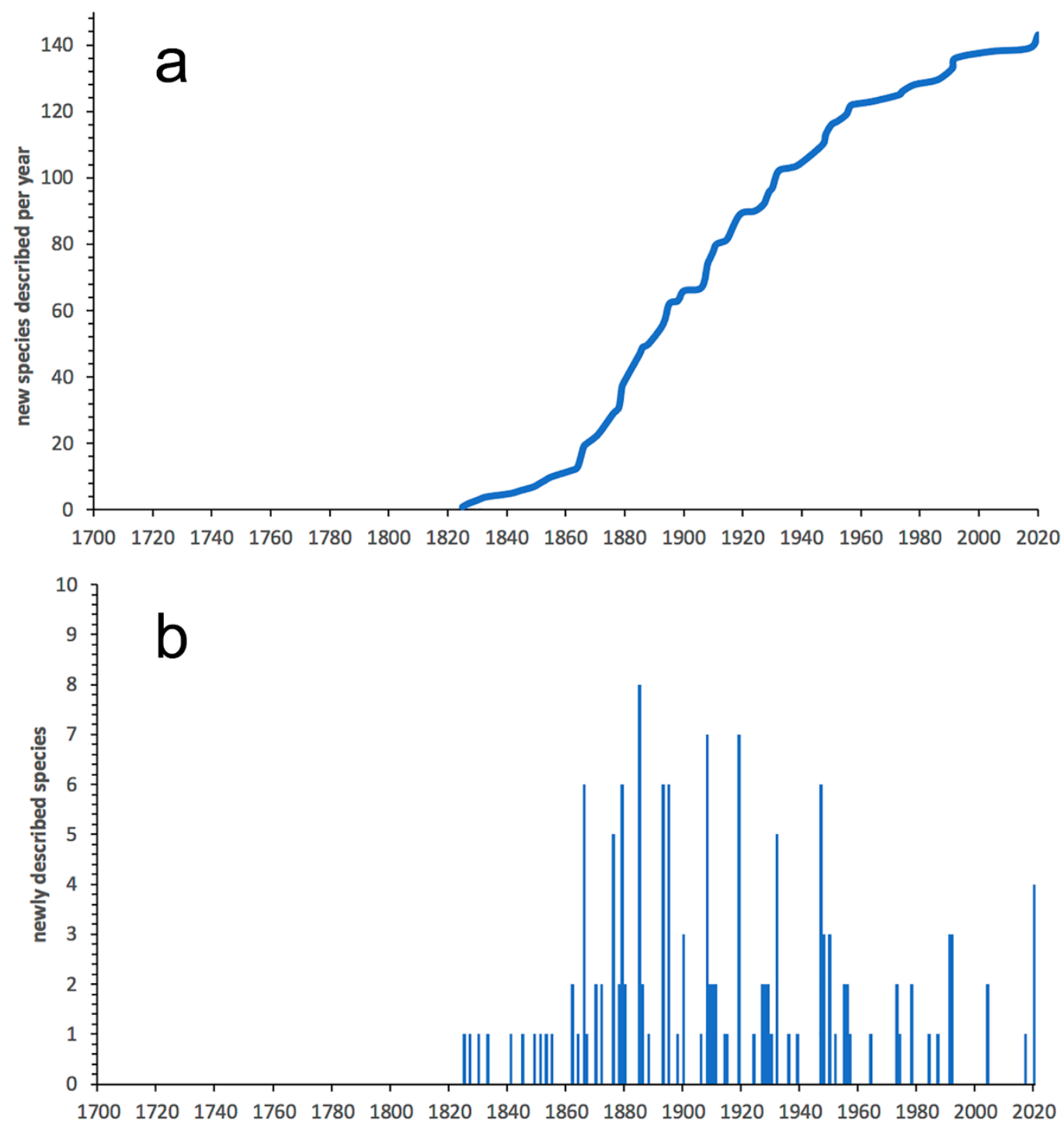

Figure 16. Holoplanktonic polychaetes. (a) Cumulative curve of newly described species through time. (b) The number of new species described per year.

The number of species of Tomopteridae is still uncertain, because many of them have not been recorded after their original descriptions, which in many cases were also incomplete. Therefore, it is difficult to know the real extent of the existing synonyms, which are not considered in the current databases on the family (Fernández-Álamo, in preparation). There are currently about 53 known species within three nominal genera, Tomopteris Eschscholtz, 1825 [222], Briaraea Quoy \& Gaimard, 1827 [223], and Enapteris Rosa, 1908 [224]. Most of them belong to Tomopteris, as the other two genera are monospecific. In fact, some authors considered the existence of Tomopteris as the single genus of the family $[225,226]$. Typhloscolecidae also includes three genera, Typhloscolex Busch, 1851 [74], 
Sagitella Wagner, 1872 [227], and Travisiopsis Levinsen, 1885 [228], but the number of species is significantly lower (i.e., about 16).

Alciopini

Members of this group were first considered as a subfamily of Phyllodocidae [189,196,229], but also as an independent family $[2,64,210,230-232]$. They were also considered as the tribe Alciopini [3,194,195], a criterion apparently confirmed by molecular analysis [205] and nowadays accepted as valid [6,233]. Alciopini have always been considered close to phyllodocids, either within Phyllodocoidea by Chamberlin [234], Phyllodocemorpha by Uschakov [235], Phyllodocida (without special category) by Dales [1], Phyllodocida: Phyllodociformia by Fauchald [118], Phyllodocida: Phyllodociformia: Phyllodocidacea by Pettibone [187] and in Phyllodocida: Phyllodocoidea by Pleijel and Dales [236]. Within the family, the genera have been divided in two morpho-groups $[189,191,198,210,237]$ which, based on a cladistic analysis, derived into the subfamilies Alciopinae and Watelinae [238].

Alciopini (Figure 15b,c) are usually classified as macrophagous visual hunters that feed on copepods, euphausiids and zooplankton, although some small-sized members also feed on diatoms and other phytoplanktonic organisms [12,239]. The recently described genus Ctenophoricola San Martín, Álvarez-Campos et al. 2021 (including two species) shows a characteristic parasitic behavior, feeding and living on ctenophores [240]. Most species are epipelagic, with a limited range of vertical migration [239]. However, some occur below the photic zone, deeper than $500 \mathrm{~m}$ depth [241] and, infrequently, in neritic environments [239]. Many Alciopini stand out by their very wide distributions, in warm waters of tropical and temperate areas of the open ocean [189]. However, some species occur in cold waters, always in the Antarctic, while they have never been recorded in the Arctic [242].

Iospilidae

Iospilids (Figure 15d) were first included in Phyllodocidae [243,244], which was then divided into Phyllodocides (benthic) and Lopadorrhynchoides (pelagic) [66]. The later included the iospilids, which were defined as subfamily (Iospilinae) within Phyllodocidae $[189,191,201,244-247]$, and as an independent family (Iospilidae) $[2,118,190,214,225,231,232,248]$. Their systematic position has also been controversial, being placed within Phyllodocoidea [234] and in Phyllodocida, within a "not recognized" suborder [118], within the superfamily Phyllodocidacea (aberrant) [187] and within the superfamily Iospiloidea [236]. More recently it has been suggested that only a rough placement of the iospilids (together with pontodorids and typhloscolecids) within Phyllodocida can be supported, while their actual phylogenetic relationships are still uncertain [249].

Members of this family seem to be motile herbivores feeding mainly on diatoms, as inferred based on body size and the lack of pharyngeal armature, while others apparently behave as ambush predators, as inferred from their appearance, which does not suggest a powerful swimming capacity [12]. In general, however, they are considered as relatively good swimmers compared to similar small-sized holopelagic polychaetes [205]. They are relatively common in open surface waters, but may occur down to $200 \mathrm{~m}$ depth and appear to be common in the Southern Ocean near the Antarctic Peninsula [205]. However, they have in fact a cosmopolitan distribution, with the scarce records in other ocean areas likely being caused by their small size and fragility leading the animals to be easily broken during towing, with their fragments being often collected but commonly overlooked in plankton samples $[231,246,247,250,251]$.

Lopadorrhynchidae

As already mentioned, members of this group (Figure 15e) were considered a pelagic tribe within Phyllodocidae [66]. They were raised to subfamily [188-190,200,201,225,244247,252-254], and to family [248], which is the currently accepted situation [6]. However, the family showed separate clades within Phyllodocidae, with Pelagobia Greeff, 1879 [72] being related to Eteone Savigny, 1822 [255], and Maupasia Viguier, 1886 [216], and Pedi- 
nosoma Reibisch, 1895 [244] having unclear relationships [3,194], and its whole phylogenetic relationships are still uncertain [249]. Accordingly, lopadorrhynchids were considered within Phyllodocida: Phyllodociformia [118], within Phyllodocidaea [187], and within Phyllodocoidea [236].

Members of this family seem to be either motile herbivores, feeding on microalgae, or predators feeding on small protists and animals, grasping the preys with their enlarged, muscular anterior parapodia and gently curved spines [12,191]. Diurnal vertical migrations from surface to deeper waters during daylight have been reported for L. brevis [247]. Many members are considered cosmopolitan. For instance, P. longicirrata, one of the most abundant species that has been collected from surface to below $4000 \mathrm{~m}$ depth [256] and throughout the world [188,189,214,232,245-247,257,258], including Arctic [256] and Antarctic [245,259-261] waters. However, its cosmopolitan status has been recently questioned. Based on morphological and molecular data, it might represent a species complex [218]. Further comparative molecular studies on material from different areas of the world are required, including specimens such as those attributed to $P$. cf. longicirrata from mid Pacific waters.

\section{Pontodoridae}

The single known pontodorid, P. pelagica, was originally placed within Phyllodocidae [72], and then raised to subfamily (Pontodorinae) $[189,201]$, and to family (within the Tribe Phyllodocidiformia) [2,6,118,144,190,230,231,248,254,262]. Due to the pharyngeal shape, the family was first considered to be related with Syllidae [225] and Nephtyidae [230]. However, the shape, size and arrangement of the pharyngeal papillae more closely resemble those of the phyllodocids. Pontodorids were placed in Phyllodocoidea [234] and in Phyllodocida, within Phyllodociformia [118], Phyllodocidacea [187], and Phyllodocoidea [236]. Nevertheless, their phylogenetic relationships are still unclear [194,249].

Pontodora pelagica seems to be a motile or discretely motile microphagous, but its real diet is still unknown [12]. The species is probably bioluminescent [189] and, although it may be relatively common in warm waters of the world oceans, it could have been overlooked in plankton samples due to its small size and transparent body [213,263]. The species was described from subtropical areas of the Atlantic Ocean (Canary Islands) and the Mediterranean [189] and later reported from the equatorial Atlantic, the Northwestern and Eastern Pacific (from Canada to Peru and Chile) [189,221,264,265], the Indian Ocean [266] and South Africa [225]. There are no records from Antarctic and Arctic waters.

\section{Tomopteridae}

Tomopterids are typically enigmatic holoplanktonic polychaetes [194], whose monophyly was the absence of chaetae except the acicular structures supporting the first two parapodia that are parts of the head [230]. Their unique morpho-physiological traits, derived from their adaptations to the holoplanktonic mode of cycle, difficult the establishment of their relationships with the other polychaetes, leading them to be considered as a clade with uncertain phylogenetic affinities [190,194,249]. Nevertheless, they are generally associated with Phyllodocida [3,188]. Their achaetous parapodia led to create the order Gymnocopa to include a single family, Tomopteridea [119]. Subsequently, the family was named as Tomopteridae $[267,268]$, habitually within Phyllodocida, but sometimes as "unrecognized suborder" [118] or as a superfamily, either Phyllodocidacea (aberrant) [187], Tomopteroidea [236] or Tomopterimorpha [269]. The aberrant character of the family seems to be accepted by many authors. They were particularly considered a very old and highly specialized group placed in Phyllodocemorpha: Phyllodociformia, emphasizing its ancient character by pointing out that it was separated very early from all other polychaetes and followed a differential evolutionary path than, for instance, Alciopini $[189,235]$. Overall, the relationships of this family with Phyllodocida seem to be scarce and even more obscure than those of the other holoplanktonic families. Accordingly, possible advances in their phylogenetic knowledge could be acquired through molecular analyses, which could even 
result in leaving them out of Phyllodocida [194]. In fact, the family has been recently placed in close relationship with Glyceriformia [4].

Members of the family are often highly motile organisms, looking like delicate transparent feathers [225] (Figure 15a), relatively easy to be imaged in their natural environment with the modern tools used in oceanographic research [270]. They feed with a short, unarmed, eversible pharynx, being either primarily herbivorous feeding mainly on diatoms (small species), primarily carnivorous (large species) or mixed feeders feeding on diatoms, protozoans and other animals (intermediate-sized species) [12]. Some of them seem to be either specialized predators or parasites of chaetognaths, which show sucking marks due to the feeding activity of tomopterids [271]. They are frequent in plankton samples, mainly from surface waters down to a few hundred meters deep, although they have also been reported as deep as $3000 \mathrm{~m}[189,225,266,272,273]$. In fact, they are used in zoogeographical studies since their distributions seemed to be related to particular water masses $[199,232,245,246,274]$. For instance, there has been a recent notable rise in the abundance of Tomopteris (Johnstonella) pacifica (Izuka, 1914) [275] and Tomopteris planktonis Apstein, 1900 [198] related to an upwelling in the thermal dome of Costa Rica [276] and of T. (J.) pacifica related to the entry of warmer and saltier waters in the Southern Adriatic Sea [277].

Tomopterids are distributed worldwide, living in oceanic and near-shore waters from polar to equatorial areas [245]. However, most species are known from only one area and only a few appear to be cosmopolitan (ex. Tomopteris apsteini Rosa, 1908 [224], Tomopteris elegans Chun, 1887 [278], T. planktonis) [279] or considered as cosmopolitan in cold waters (T. septentrionalis) [274].

Typhloscolecidae

Typhloscolecids (Figure 15f) have particularly complex phylogenetic relationships with the rest of polychaetes, as a result of combining the adaptations to pelagic and ectoparasitic modes of life. The name of the family was proposed by Uljanin [207], who relate it with Phyllodoce due to a supposed similarity of its "swimming paddles" with the foliose dorsal cirrus characteristic of this genus. Later, they were considered as possible neotenic forms of benthic organisms [191] or, more generally, as an independent family within Phyllodocida [1,280], either within an "unrecognized suborder [118], within Phyllodocidacea, as Typhloscolecidae (aberrant) [187] or within Phyllodocida: Typhloscolecoidea [236]. More recently, Typhloscolecidae were included within Phyllodocidae [281], although this was later considered unacceptable owing to analytical problems [282].

Members of the family are motile or discretely motile parasitoids on chaetognaths $[12,283]$. They may occur attached behind the head of their host chaetognaths [284], which may even lose their heads as a result of the activity of the parasites $[283,285]$. They may live from surface waters to abyssal depths $[3,189,286]$. In some cases (e.g., the species of Travisiopsis), the adults live in the deep sea, but the juveniles may sometimes be found near the surface [225].

Yndolaciidae

Yndolaciids form a small family whose phylogenetic relationships are still uncertain. They were proposed to be raised to order level [287], but Buzhinskaja [288] considered this as premature due to the poor existing knowledge, thus keeping them as a family within Phyllodocida. Although not proved, they have been considered as carnivores [12]. Moreover, they are only known from deep waters and just known from specific sites, such as the Gulf of Guinea, Southeastern Atlantic [193], the Cape Verde archipelago, Northeastern Atlantic [289], the Mid-Atlantic ridge [290], and the Arctic Ocean [288].

\subsubsection{Nephtyidae}

Nephtyidae Grube, 1850 [119] is a morphologically well-defined and a monophyletic group within Phyllodocida [2,4,291]. Its monophyly is based mainly on the presence of interramal branchiae attached ventrally to the notopodia (although absent in some taxa) and 
the single median pygidial cirrus, which are both unique features within the order [230,292]. The family was at first included within 'Phyllodociformia' along with Phyllodocidae and Alciopini [293]. Later, most errant families were regrouped within 'Nereimorpha' (excluding only Amphinomidae and 'Spiomorpha') [294]. 'Phyllodocemorpha' and 'Nereimorpha' were again distinguished [235]. After the erection of polychaete orders, Nephtyidae remained within Phyllodocida, although with an uncertain position [1]. Different analyses placed them close to Phyllodocidae, Paralacydoniidae, Glyceridae Goniadidae, and Pisione Grube, 1857 [2,295], or as sister group to Glyceridae and Goniadidae [292] or to Hesionidae, Pilargidae, and Nereididae $[4,126,291]$.

The family includes at present four genera and almost 150 accepted species [6]. Most of them are within Aglaophamus Kinberg, 1866 [296] (Figure 17a,b) and Nephtys Cuvier, 1817 [297] (Figure 17c,d), while Inermonephtys Fauchald, 1968 [298] and Micronephthys Friedrich, 1939 [299] include only 10 and 15 species, respectively. A large number of these species (over 50\%) were described between the mid-19th and 20th centuries (1865-1972), following important oceanographic expeditions, such as the SMS Gazelle (1874-1876), the dredging by the U.S. coast survey steamer "Blake", the Challenger (1872-1876), the Hirondelle and Princesse-Alice oceanographic campaigns (1885-1910), the F.I.S. “Endeavour" (1909-1914), the Allan Hancock Pacific Expedition, the Swedish Deep-sea Expedition (1947-1948), and the USNS Eltanin and Staten Island Cruises [88,138,203,300-305].

Many taxonomic revisions and major works covering regional geographic areas were subsequently published $[48,141,144,201,225,306-341]$. Overall, this gave rise to a regular trend of species description with six major peaks during the 20th century (Figure 18a,b), when a significant number of species were described mainly from the East Pacific $[141,319]$, Australia [325,337,338], and tropical West Pacific areas [298,334].

Many taxonomic problems have already been solved, but doubts still remain concerning the boundaries among genera and the correct allocation of many species. Molecular phylogenetic analyses recently started to address these questions [342,343]. The two most speciose genera, Nephtys and Aglaophamus, appears to be clearly monophyletic, while poor representation of the two other genera did not allow a proper assessment [343]. In this analysis, only $18 \%$ of the total known species were included, which was not fully representative of the diversity of the family. For instance, (1) the species of Aglaophamus having lyriform chaetae were not included, which did not allow to check whether they would consistently group with the species lacking those chaetae; (2) Nephtys was subdivided in two morphologically distinct clades; (3) Micronephthys was only represented by two abranchiate and one branchiate species that group in different, quite distant clades, for which the erection of a new genus has been a matter of discussion [307,343]; and (4) Inermonephtys is represented by only one species falling outside the nephtyid clade, although with very low support. All these results denoted a clear lack of stability and the need for further reassessment of the phylogenetic relationships within the family at the genus level.

Members of the family are mainly predators, although they may exceptionally be deposit-feeders in highly dense populations [12,344,345]. Most often, they hunt within the sediment, capturing any other motile invertebrates (including smaller conspecifics), although they may also be highly selective [12,344-346]. They are common in most coastal and offshore environments around the world and at all depths, including the deepsea $[138,203,234,301,347,348]$ and extreme habitats, such as methane seeps, despite the apparently poor tolerance to sulphide [349-351]. However, comprehensive studies on deep-sea species are lacking for all the oceanic basins. Its abundance is highly variable, but may be so high that, especially in coastal environments, large-bodied species are important components of the trophic network and are often exploited as fish baits $[167,345,352,353]$. 


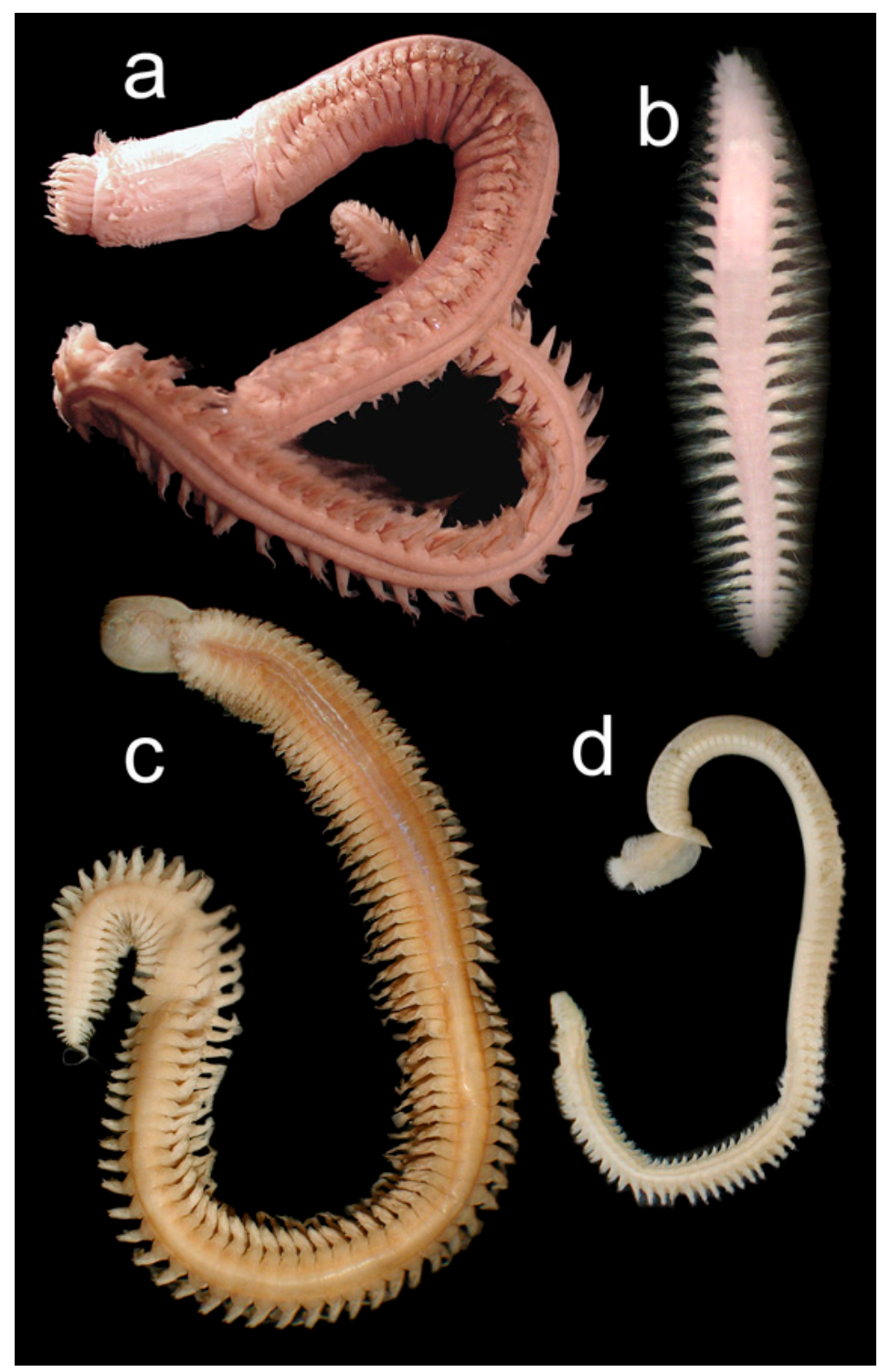

Figure 17. Nephtyidae. (a) Aglaophamus trissophyllus (Grube, 1877) [300]. (b) Aglaophamus elamellatus (Eliason, 1951) [348]. (c) Nephtys hombergii Savigny in [68]. (d) Nephtys capensis Day, 1953 [354].

Habitat preferences may vary considerably, mainly depending on water depth, salinity, grain size and mud content [355]. Different species may co-occur, sharing resources although slightly segregated by small differences in life-traits [355-358], such as the periodic reproductive failures allowing the sympatric distribution of N. hombergii and Nephtys caeca (Fabricius, 1780) [70] reported by Olive and co-authors [356,359]. Life-stages can be environmentally segregated, such as the adult $N$. hombergii living in intertidal mudflats and the juveniles inhabiting the sublittoral [360]. Shallow water estuarine species may tolerate a wide range of salinities and a few occur in nearly freshwater (e.g., Micronephthys oligobranchia (Southern, 1921) [361], Nephtys fluviatilis Monro, 1937 [362], and Nephtys polybranchia Southern, 1921 [361]) [298,332]. Most species prefer sandy bottoms with variable mud and clay contents, where they move freely to as deep as $20 \mathrm{~cm}$ within the sediment [363]. 

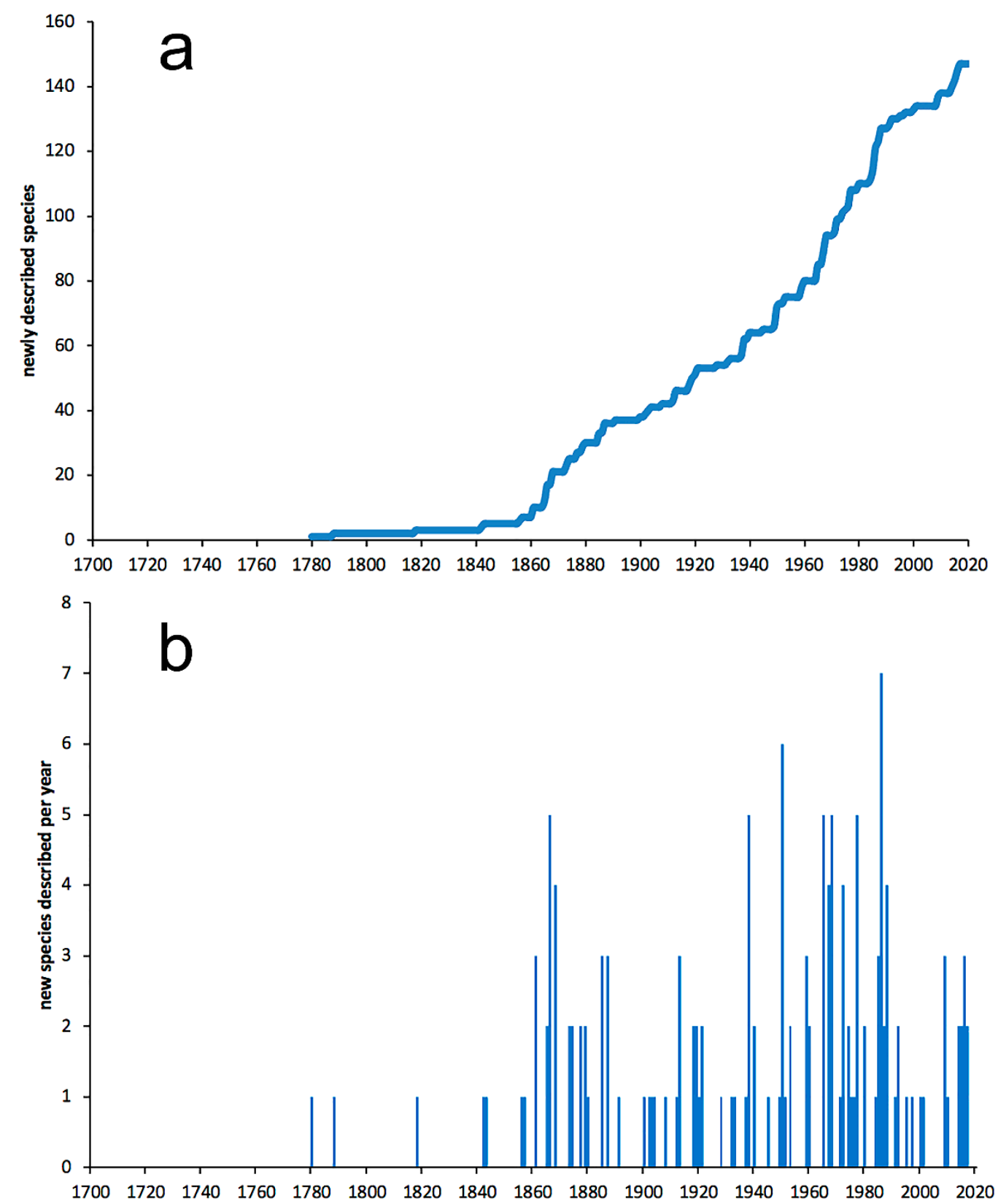

Figure 18. Nephtyidae. (a) Cumulative curve of newly described species through time. (b) The number of new species described per year.

Despite the multiple areas of the world (e.g., Arctic, Atlantic, Pacific, and Antarctic Oceans, Mediterranean, Black, and Red Seas) covered by the taxonomic revisions mentioned above, there are still geographic areas very poorly documented, such as the Indian Ocean and the African and South American coasts. Furthermore, comprehensive deep-sea studies are lacking for all the oceanic basins. Only 13 deep-sea species are known to date, from the E Pacific, N Atlantic, Antarctic and Tasman Sea, the majority of which described during the 20th century $[138,203,234,301,347,348]$. As a consequence, many currently accepted species are known only from their original descriptions, that are often very short, incomplete and may lack illustrations (or are of low quality). This casts doubts on their validity, particularly when trying to compare them with others described for the same location. To even complicate the situation, the existence of cryptic species has already been pointed out (e.g., Micronephthys longicornis (Perejaslavzeva, 1891) [364], Micronephthys sphaerocirrata (Wesenberg-Lund, 1949) [365], Nephtys cirrosa Ehlers, 1868 [65], and 
Nephtys hombergii Savigny 1822 [366]) [318,333,367]. Therefore, some (if not many) widely widespread taxa may likely involve more than one species (e.g., Aglaophamus verrilli (McIntosh, 1885) [88], Inermonephtys inermis (Ehlers, 1887) [301], Micronephthys sphaerocirrata, Nephtys caeca (Fabricius, 1780) [70], and Nephtys paradoxa Malm, 1874 [368]) [318,322,333]. This, together with the fact that several species still need to be correctly allocated within the family, denote that further local works and comprehensive revisions, preferably including molecular tools, are still required.

\subsubsection{Polynoidae}

Polynoidae is included within the clade Aphroditiformia (Aphroditoidea) and is the largest polychaete family after Syllidae [6]. Members of the family typically have more or less similar segments all along the body and, together with all other members of the clade, are commonly known as scale-worms, due to the key trait of having the dorsum more or less covered by elytra or scales (Figures 19a-d and 20a,b).

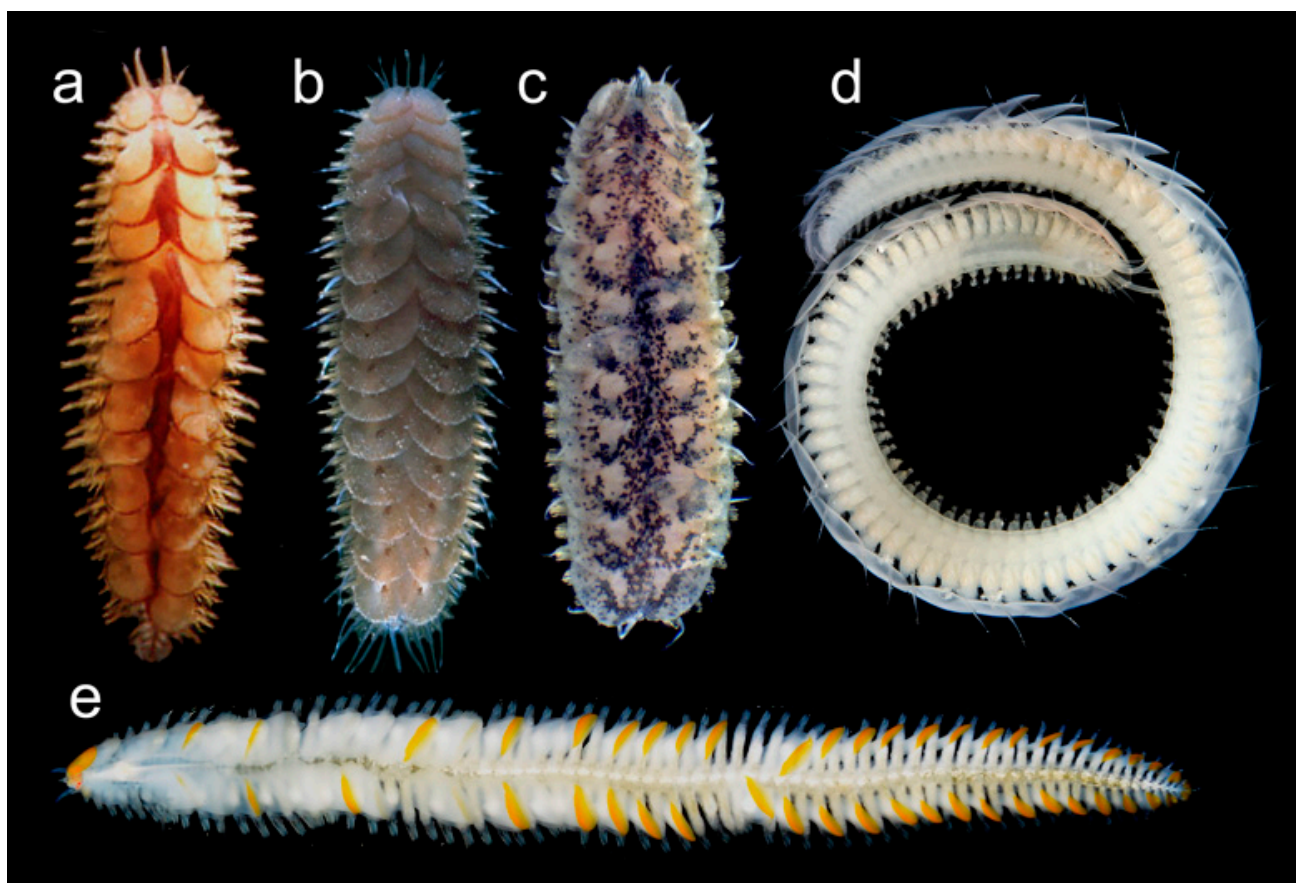

Figure 19. Polynoidae. (a,b) Two different color morphs of Harmothoe imbricata Linnaeus, 1767) [75]. (c). Lepidonotus tenuisetosus (Gravier, 1902) [369]. (d). Hololepidella sp. from a sea urchin Toxopneustes pileolus (Lamarck, 1816) [370]. (3) Pottsiscalisetosus praelongus (Marenzeller, 1902) [371], symbiont of the starfish Luidia maculata Müller et Troschel, 1842 [372]. (d,e) Photos by J.V. Deart.

Despite its relevancy among polychaetes, the phylogenetic and taxonomic relationships within the family have been seldom approached. Early studies based on morphological characters $[373,374]$ and general analyses dealing with higher taxa relationships [2,292] supported the monophyly of Aphroditiformia, but the position of Polynoidae remained unresolved. Conversely, Struck, et al. [375] placed Pisionidae within Aphroditiformia and, while refusing the monophyly of the suborder, strongly supported the placement of Polynoidae as a well-supported clade within them. Further combined molecular and morphological approaches placed the family as sister group to Acoetidae and Iphionidae [376,377]. More recently, the monophyly was recovered both for the whole Aphroditiformia, with a strong support and having the presence of elytra as apomorphic trait, and for Polynoidae, although some shallow-water (e.g., Lepidastheniinae) and deep-sea (e.g., Branchinotogluminae and Macellicephalinae) subfamilies revealed to be paraphyletic [377,378]. Particularly among deep-sea polynoids, there seems to be at least two contrasting interpretations, 
which include both a small number of species placed within a large number of subfamilies [377,378] and the synonymy of up to ten subfamilies within Macellicephalinae, which formed an homogeneous clade defined by the absence of lateral antennae [379]. Interestingly, the later agreed with an early postulate based on morphological characteristics, which included five deep-sea subfamilies established by Pettibone [380] (i.e., Bathyedithinae, Bathymacellinae, Macellicephaloidinae, Macelloidinae, and Polaruschakovinae) within the Macillicephalinae as one natural group [381].

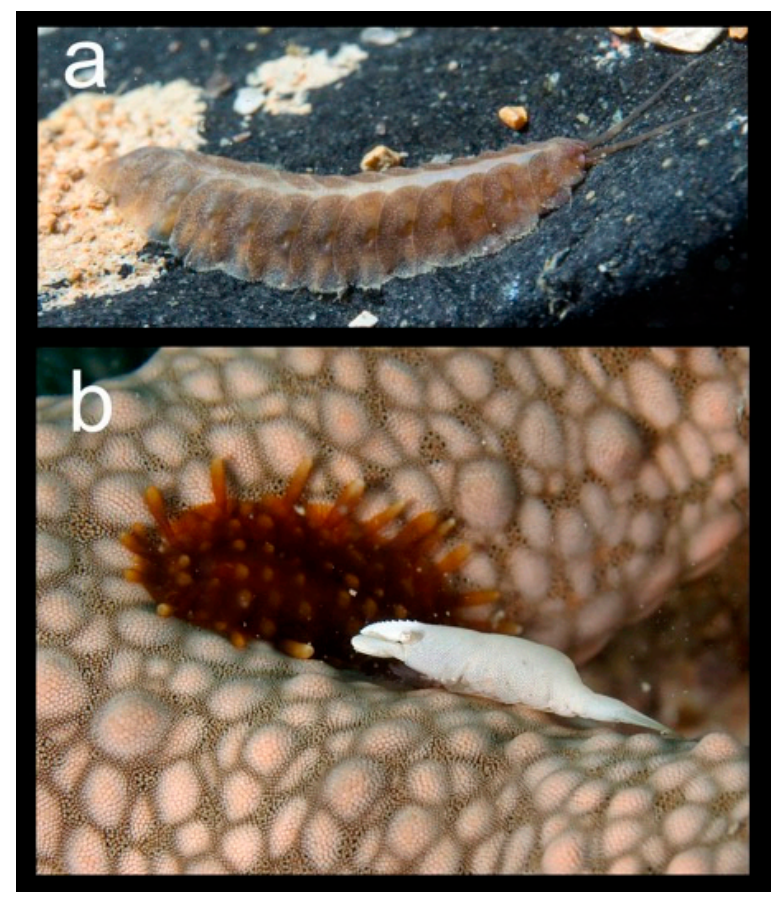

Figure 20. Polynoidae. (a) Malmgrenia mcintoshi (Tebble \& Chambers, 1982) [382] in its natural habitat. (b) Asterophilia culcitae Britayev \& Fauchald, 2005 [383] (brown) and the shrimp Zenopontonia soror (Nobili, 1904) [384] (white) on the surface of a starfish of the genus Nardoa Gray, 1840 [385]. Photos by: (a) T.I. Antokhina, (b) J.V. Deart.

The first still valid species of the family, Lepidonotus squamatus (Linnaeus, 1758) [62], was described as Aphrodita squamata Linnaeus, 1758 [62]. Since then, 1486 species have been described, of which 871 are currently considered as valid and grouped into 154 genera within nine subfamilies, together with 13 genera that were not placed in any of these subfamilies [6]. Almost half of all known species (i.e., 433) belong to the Polynoinae, while the Admetellinae, Eulagescinae and Uncopolynoinae consist on one to eight species [6]. The three largest genera, Harmothoe Kinberg, 1856 [111], (150 species), Lepidonotus Leach, 1816 [386] (79) and Eunoe Malmgren, 1865 [387] (43) account for about 32\% of all known species, while nearly half of all known genera (i.e., 48\%) are monotypic [6].

The rhythm of new species descriptions (Figure 21a) mirrors that of the whole "Polychaeta" [61] and Phyllodocida (this paper). From 1758 to 1850 (with 26 species), a limited number of generalist taxonomists described 0.3 species per year; from 1850 to 1939 , about 400 species were described. There was a ten-year parenthesis during the second world war (with eight species described, less than one per year) and then a highly productive reprise, which involves a high number of specialized taxonomists allowing to describe almost 400 more new species to date (i.e., 5.7 new species per year) (Figure 21b). Moreover, as the number of newly described species did not show traces of stabilization (Figure 21b), it is expected a great increase of the species diversity of the family. 

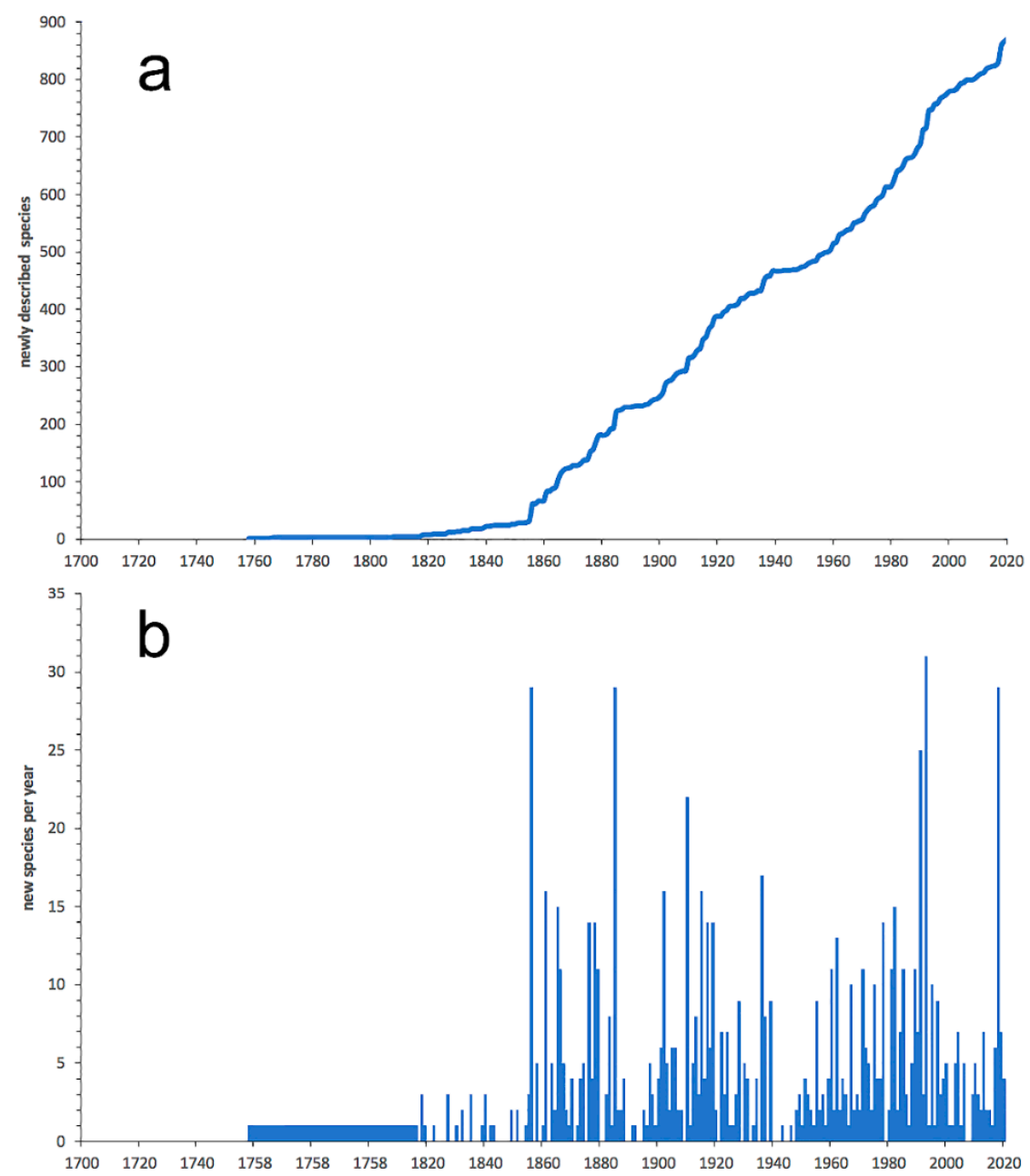

Figure 21. Polynoidae. (a) Cumulative curve of newly described species through time. (b) The number of new species described per year.

An additional fact contributes to increase the complexity of the taxonomy of Polynoidae, as one can also expect the discovery of new sibling or pseudo-sibling complexes. Although poorly documented to date, some cases have been reported for free-living polynoids with large distribution ranges, like Harmothoe imbricata (Linnaeus, 1767) [75]. The species is well-known to show numerous distinct color morphotypes (Figure 20a,b) and the 10 color morphs inhabiting Scandinavian and Svalbard coasts revealed to belong to a single polymorphic species [388]. However, an analysis of a wider geographic range revealed a species complex composed of at least four diverging lineages [107]. Similar situations occur within the symbiotic taxa, particularly with the polyxenous species (i.e., those showing a wide host-ranges). The number of species of Branchipolynoe Pettibone, 1984 [389], which was four (with wide distributions and associated to different deep sea mytilids) until 2019, was recently doubled after a study of Pacific methane seeps and hydrothermal vents [106]. However, still nowadays, the most spectacular case is that of Harmothoe lunulata (Delle Chiaje, 1841) [390]. The species used to be known as associated with numerous species of echinoderms, cnidarians, polychaetes, sipunculans and balanoglossids. However, it is currently accepted that these partnerships involve at least 15 different species from three different genera (i.e., Malmgreniella Hartman, 1967 [203], Lepidonopsis Pettibone, 1977 [391] and Wilsoniella Pettibone, 1993 [392], the latter currently accepted as Pettibonesia Nemésio, 2006 [393]), showing clear biogeographic segregation and, in many cases, specific adaptations, such as color mimicry [392]. 
To date, molecular data available at GenBank refer only to about 80 species of Polynoidae, which represents no more than $10 \%$ of the total number of known species, which certainly gives room to the discovery of new species complexes. Surprisingly, despite the number of known shallow-water species is higher than that of deep-sea relatives, about half of the molecular studies dealing with polynoids refer to deep-sea species. Therefore, to improve our understanding on the phylogeny and classification of Polynoidae, further efforts must be addressed to increase the number of molecular analyses on shallow-water species (especially Arctonoinae and Lepidasteniinae), while continuing with the studies on deep-sea species.

A particular aspect that has not been addressed for the whole family, e.g., [376,377] is the possible origin of the symbiotic mode of life typically occurring in many polynoids [17]. Conversely, based on a limited approach mainly including deep sea species, it has been suggested that: (1) most basal species of the subfamily Polynoinae are obligate symbionts showing specific morphological adaptations; (2) commensal and free-livings modes of life have evolved several times; and (3) the obligate coral commensals were monophyletic [394]. Based on a still more limited dataset, Shields et al. [395] just confirmed the commensal association of Eunoe bathydomus (Ditlevsen, 1917) [396] with holothurians, in addition to supporting the specific difference of two geographically distant (non-symbiotic) morphotypes of what could be Harmothoe cf. glabra (Malmgren, 1865) [387].

At present, nine subfamilies are recognized within Polynoidae [6], which partially coincide with the structure proposed by Bonifácio and Menot [379]. Overall, systematics of polynoids at subfamily and genera levels is among the worst developed within polychaetes, and there are no recent revisions on the family. The number of subfamilies varied through time from 9 to $21[3,6,52]$ and the boundaries between most of them are not clear, while there are a number of genera whose assignment to a given subfamily is not possible. Some subfamilies (e.g., Uncopolynoinae, Branchipolynoinae, Polaruschakovinae) include one or few species, while among genera many are monotypic (e.g., Capitulatinoe Hanley \& Burke, 1989 [397], Gastrolepidia Schmarda, 1861 [112], Pottsiscalisetosus Pettibone, 1969 [398], Alentiana Hartman, 1942 [399]), and some are giant (including 100 species or more) and paraphyletic with indistinct boundaries (e.g., Harmothoe, Lepidonotus).

The vast majority of polynoids are highly motile, typically benthic organisms that can be found in any oxic marine environment. However, there are about ten species (belonging to Drieschia Michaelsen, 1982 [400] and Podarmus Chamberlin, 2019 [234]) known to be holopelagic [12] and a few may inhabit brackish environments [401] or anchialine caves [402]. They usually occur in very low densities, but local episodes of high abundance have been reported, likely in connection with recruitment events [403] or introduced/invasive species (Marwa Chaibi, personal communication). Most polynoids are typical free-living organisms, being basically sit-and-wait predating or active hunting carnivores, although some may feed on algae or on vent and seep bacterial mats [12]. Moreover their diets may also include different organisms that could either be real targets or captured as bycatches of the real preys (e.g., diatom thecae, algal filaments, crustacean exoskeletons, hydroid thecae, bivalve shells, gastropod radulae, bryozoan skeletons, sponge spiculae, and ciliate loricae), and often include remnants of other polychaetes, such as nereidids or phyllodocids, but also other polynoids, even members of the own species [404]. Whether this may be a real cannibalistic behavior or the result of territorial aggressive interactions is still unknown. However, the fact that territoriality leads to strong and very complex aggressive intra-specific interactions is well known among Polynoidae. For instance, this behavior has been recently reported in free-living species of the deep sea genus Peinaleopolynoe Desbruyères \& Laubier, 1988 [405], where the purpose was not described (but certainly looks like territoriality) [406] but mainly in symbiotic $[16,17]$ species. Their species diversity highly depends on the studied region, varying from very high (e.g., 114 in the Caribbean and Gulf of Mexico) to very low (e.g., four in the Baltic Sea or seven in Chilean coasts). The most speciose regions are the North Pacific and Tropical Indo-Pacific, including the coastal 
Indian Ocean (94 species and 42 genera each), the North Atlantic (79 species and 38 genera) and the Antarctic Ocean (71 species and 32 genera) (Supplementary Figure S1a).

Polynoids are highly diverse in almost all marine environments, from cold Arctic and Antarctic to tropical waters, and from intertidal to deep-sea habitats, although they are absent in fresh waters and their diversity also declines in brackish waters [381]. For instance, while 47 species have been recorded in the Mediterranean Sea [407] (salinity $=36-$ $40 \%$ ), in the adjacent Black Sea (salinity $=18 \%$ ) there are only four known species [408]. Among the family, the most widely distributed species are the free-living H. imbricata and L. squamatus, known from coastal boreal and arctic Atlantic waters, as well as from the Pacific and Arctic Oceans (Supplementary Figure S2a,b). However, the former revealed to be a cryptic species-complex [107], while the status of the later has not yet been checked. Moreover, concerning L. squamatus, data from OBIS do not reflect its real distribution, as most Pacific records, derived from Uschakov [381], are no included. Symbiotic species also seem to have very wide distributions across tropical Indo-Pacific waters, such as Hololepidella nigropunctata (Horst, 1915) [409] or Paradyte crinoidicola (Potts, 1910) [410-412]. However, at least the first seems to be a species-complex (Britayev and Fiege, unpublished data). Overall, further efforts (including molecular analyses) are needed to clarify the status of most polynoids having such wide distributions.

The latitudinal diversity gradient traditionally assumed for most benthic macrofaunal organisms seems not to be evident in polynoids, which show a similar bimodal pattern to Phyllodocida overall (Figure 5b), with that in the northern one being significantly higher (Supplementary Figure S1b,c). There is a maximum of diversity in boreal waters that obeys to a much higher sampling effort, particularly in the high latitudes of the Northern Hemisphere, while a lower effort probably explains the low diversity of equatorial seas (Supplemental Figure S1a,c). In fact, recent surveys in the tropical West-Pacific have shown that the diversity of these tropical waters is comparable or even higher than in temperate latitudes $[79,413,414]$. Moreover, as much as 76 species have been recorded in the South China Sea $[413,414]$, which is comparable with the entire North Atlantic (79 species). Up to 57 species have been reported along Indonesian coasts [79], which is close to or even higher than the diversity of the well-studied Mediterranean, North, or Norwegian Seas. Taking this into account, together with high habitat diversity of the tropical areas, we certainly expect a significant increase in the number of species of polynoid being reported from these regions.

Polynoids have revealed to be particularly conspicuous in the deep-sea. At least 140 species (i.e., ca. 16\%) have been found living deeper than $1000 \mathrm{~m}$, some of them reaching the 10,000 m depth at the Kurile-Kamchatka Trench [235]. They are frequent inhabitants of vent and seep sites, organic falls and other chemosynthesis-based habitats from the Atlantic and Pacific Oceans, where numerous new species are being described thanks to new observation and sampling technologies used in recent expeditions e.g., $[13,14,379,406]$. Other deep sea habitats are also being explored and proved to be inhabited by polynoids, such as sea-mounts in the Indian Ocean [394] or mud volcanoes in the Atlantic Ocean [415]. Therefore, deep-sea habitats seem certainly to be underestimated in terms of polynoid diversity. In line with this, it is not surprising that the number of new deep-sea polynoids described over the past 10 years almost doubled that from shallow waters (i.e., 37 vs. 18 , respectively). Many more species remain to be described, particularly in the intertidal Antarctic and tropical waters, which are much poorly explored than the shallow subtidal Arctic Ocean and temperate European and North American waters, but certainly also in deep-sea environments.

Some deep sea polynoids observed thanks to the numerous images captured in recent expeditions are holoplanktonic species with specific adaptations to this particular environment (e.g., https: / /www.youtube.com/watch?v=yrlSmxG5yZY, accessed on 18 November 2020). However, like their shallow-water relatives, most of them are benthic, many likely correspond to undescribed species, and quite a lot seem to be symbionts. Among them, new discoveries include species associated with carnivorous 
sponges [416,417], black corals [418], cold-water corals [419,420], holothurians [395,421], and acorn worms (https: / / www.youtube.com/watch?v=yrlSmxG5yZY, accessed on on 18 November 2020).

Actually, polynoids are not only the family including the most symbiotic species within Phyllodocida (e.g., Figure 19d,e and Figure 20b), but also within the whole 'Polychaeta', with 220 (ca. 25\%) species involved in about 600 (36\%) relationships [16,17]. The vast majority are roughly considered as commensals, particularly in taxonomic papers, while basic biological, ecological and ethological knowledge is often lacking [16]. Indeed, some widely accepted "commensals" revealed to be mutualists when deeply studied, and only four (i.e., Gastrolepidia clavigera Schmarda, 1861 [112], Branchipolynoe seepensis Pettibone, 1986 [422], Eunoe opalina McIntosh, 1885 [88], and Thormora johnstoni (Kinberg, 1856) [111]) turned out to be parasites [16].

Still, nowadays, nothing clearly allows to explain the astonishing dominance of polynoids among symbiotic polychaetes. A possible reason is the use of free-living traits [12] as adaptations to a symbiotic life [16]. For instance, the pharyngeal biting during intraspecific fighting known in free-living species, such as the deep-sea, hydrothermal vent Peinaleopolynoe orphanae Hatch \& Rouse, 2020 in [406]. This behavior acquires a dramatic intensity in the symbiotic Ophthalmonoe pettiboneae Petersen and Britayev, 1997 [423],which use violent attacks to discourage their conspecifics when trying to occupy their hosts [424] Britayev \& Martin, unpublished results]. Similarly, there is a remarkably absence of key taxonomic differences between many symbionts and their free-living relatives, while "free-living genera" often include symbiotic species and vice-versa. For instance, 20 over the 150 known species of Harmothoe are symbionts, or six over 40 in Eunoe.

However, there are specific adaptations to a symbiotic mode of life. Some affect the color which may vary in symbionts with respect to their free-living relatives, even if they belong to the same species. In Lepidonotus glaucus (Peters, 1854) [425] the specimens living with eunicid hosts were almost black, while the free-living ones were much paler [53]. Coloring may also vary among symbiotic con-specifics living with different hosts, as in Gastrolepidia clavigera Schmarda, 1861 [112,426]. The possible origin of the color mimicry, as well as whether an individual may or not change its color depending on that of the host [17] has not yet been solved.

Mimicry may also be achieved by morphological adaptations (e.g., in antennae, palps, tentacular and dorsal cirri, and elytra) simulating parts of the host body. Additionally, some parts of the body tend to be simplified (e.g., small elytra lacking ornamentation, subbiramous parapodia with reduced notopodia and a few or no notochaetae), typically in bivalve endosymbionts and tube dwelling species [17], attachment structures may be developed (e.g., simplified, hooked chaetae or sucker-like parapodial lobes) or sensory organs may be modified (e.g., eye size and position) [16,17]. Specialized behavioral traits have been developed, such as host/symbiont co-ordination in movements and feeding [427] or distant host-recognition mechanisms, likely chemically mediated [17]. The study of the chemically mediated behavioral interactions between hosts and symbionts lead also to discover that some hosts may also recognize the symbionts [428]. This imply that hosts also gain some benefits (e.g., defense against predators or cleaning), which led to recent reconsideration of some commensal associations as mutualisms [16].

The problem of lacking information also makes it difficult to assess the real extent of the associations established by symbiotic polynoids. Many scale-worms are known to be associated with one (or a few, closely related) host species. For instance, Medioantenna variopinta Di Camillo, Martin and Britayev, 2011 [429] associated with the hydrozoan Solanderia secunda (Inaba, 1892) [430] or Adyte hyalina (G.O. Sars, 1873) [431] associated with two related species of echinoids (Echinus esculentus Linnaeus, 1758 [62] and Gracilechinus acutus (Lamarck, 1816) [370]) [17,429]. In the other extreme, a few scale-worms appear to be associated with many hosts that frequently belong to the same taxa (i.e., class, order or even family), such as Paradyte crinoidicola (Potts, 1910) [410] known to live on ca. 20 species of unstalked crinoids [432], or G. clavigera living with 13 species of tropical holothuri- 
ans $[426,433,434]$. In addition, these widely polyxenous species often show specialized morphological adaptations, like the hooked ventral chaetae of P. crinoidicola [435] or the ventral sucker-like lobes of $G$. clavigera $[426,436]$. The degree of polyxeny of some species is still not well-known and for instance, Asterophilia culcitae Britayev \& Fauchald, 2005 [383], was always reported as exclusive associate of asteroids until found on crinoids [412] and holothurians [437].

From the point of view of biodiversity, however, the most interesting species are those showing polyxenous associations involving hosts from different taxonomic groups, like some species of Hololepidella Willey, 1905 [438] and Arctonoe. Hololepidella nigropunctata (Horst, 1915) [409] is known to live with sixteen echinoderm species (mostly ophiuroids, but also asteroids and one echinoid), one sponge and one cnidarian. Arctonoe pulchra (Johnson, 1897) [439] with six echinoderms, two mollusks and one polychaete, and Arctonoe vittata (Grube, 1855) [220] with as many as 40 species including cnidarians, polychaetes, mollusks, crustaceans, and echinoderms [16,17]. This large number of host species may sometimes (but not always) be explained by combined effect of hosts' biogeographic distributions and the development of symbiont's preferences for a given host species, e.g., in the case of $A$. vittata [440-443], but the possibility of hiding cryptic species-complexes cannot be discarded.

On the other hand, it must be highlighted that, although less reported than the inverse situation, polynoids may act as hosts. For instance, they are known to host epizootic kamptozoan entoprocts, which occur between parapodia and below elytra in Lepidonotus clava (Montagu, 1808) [444] or to be parasitized by numerous species of copepods [52,445].

\subsubsection{Sphaerodoridae}

Recent molecular phylogenetic analyses assessed the monophyly of Sphaerodoridae [446], confirming a previous assumption based on the presence of conspicuous epithelial tubercles arranged in rows (e.g., [446-449]). As a result of these analyses, a new classification was proposed, gathering long and short bodied forms in two major clades, respectively [450].

The family currently includes 131 species classified in eight genera [6,446,447,450-453]. As currently delineated, the most speciose genus is Sphaerephesia Fauchald, 1972 [138] (36 species), followed by Sphaerodorum Örsted, 1843 [71] (24), Sphaerodoridium Lützen, 1961 [454] (24), and Geminofilum Capa et al. 2019 [453] (19). In turn, Commensodorum Fauchald, 1974 [455] is monospecific, with Commensodorum commensalis (Lützen, 1961) [454] having a particularly remarkable external morphology, with reduced epithelial tubercles [453].

In general, sphaerodorids are poorly studied, as evidenced by the fact that several species have been reported once or are only known from the holotype e.g., [327,455-459]. Likely, this was due to their small size and collecting difficulties [447]. In fact, they were overlooked until the 1970s, when a high number of species were discovered and described, a trend that continues today (Figure 22a,b). Indeed, $85 \%$ of the known species have been described in the last 50 years.

Long-bodied sphaerodorids are morphologically homogeneous, show obvious segmentation and macrotubercles with terminal papillae above parapodia forming two longitudinal rows, together with reduced dorsal cirri or microtubercles $[446,450,455,460]$, and belong all them to Sphaerodorum [450] (Figure 23a). They were long time considered as belonging to three distinct genera: Ephesiella Chamberlin, 1919 [234], Ephesiopsis Hartman \& Fauchald, 1971 [327], and Sphaerodorum, based on their chaetal morphology (only compound, both compound and simple, and only simple, respectively) (e.g., [327,450,455]). The presence of pseudocompound chaetae-apparently simple but with an oblique indentationhad been reported in some species of the three genera (e.g., [450,461-463]). Doubts on the usefulness of chaetal arrangement to distinguish between genera were early indicated [464]. Then, the results of the analyses of nuclear and mitochondrial markers confirmed the syn- 
onymy of the genera and proved chaetal morphology as being highly variable within the group, but valuable for species discrimination [450].
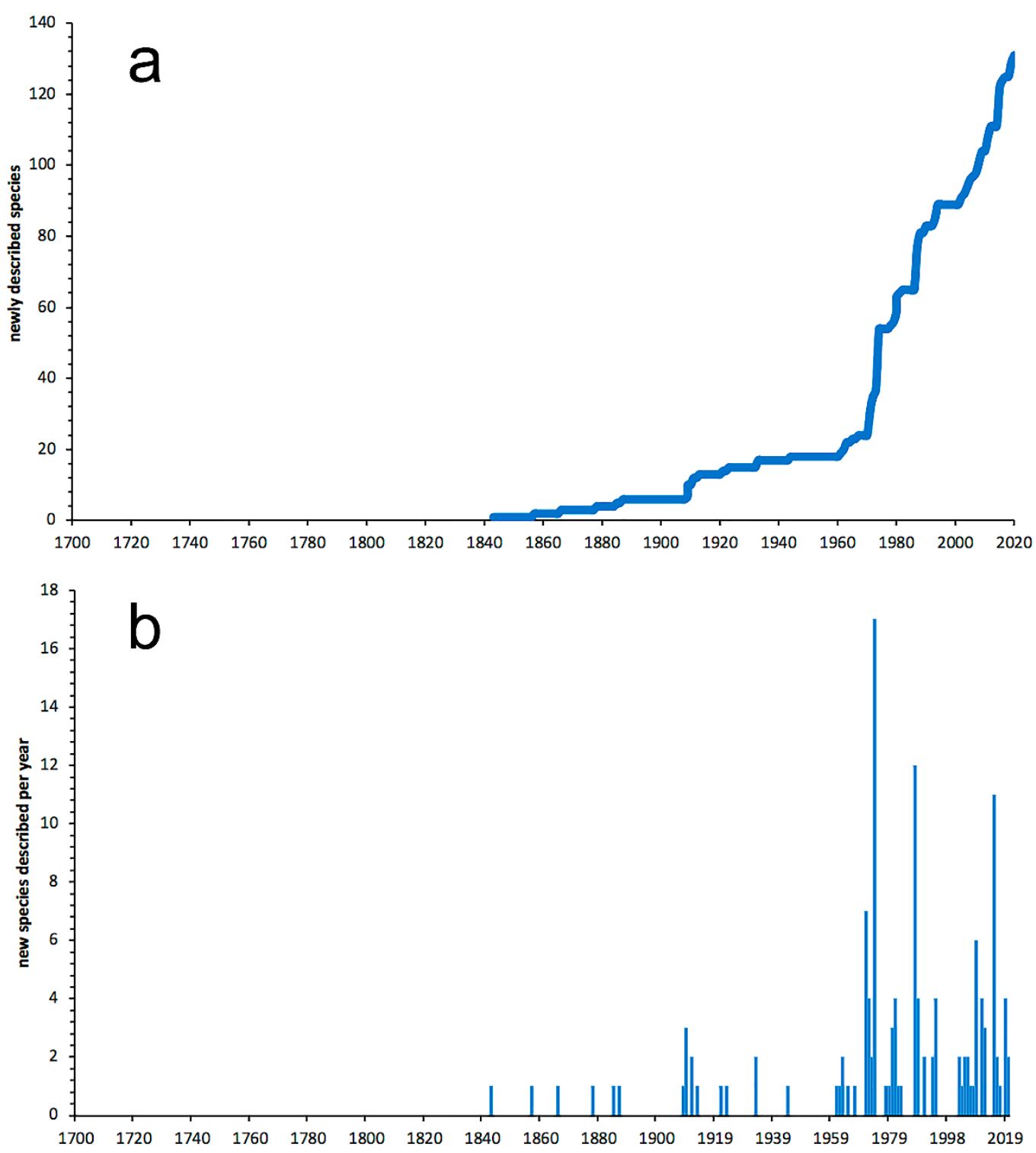

Figure 22. Sphaerodoridae. (a) Cumulative curve of newly described species through time. (b) The number of new species described per year.

Short bodied sphaerodorids show a broader morphological diversity, especially in number and arrangement of dorsal epithelial tubercles [446,447,455]. The classification and nomenclature have changed with time, with the most recent versions reflecting evolutionary relationships. Before this systematic revision, the morphology, number and arrangement of dorsal epithelial tubercles were considered among the most taxonomically informative features: (1) Euritmia Sardá-Borroy, 1987 [458] and Amacrodorum Kudenov, 1987 [465] lacked large tubercles (macrotubercles) but were completely covered by small papillae, Commensodorum also lacked large macrotubercles and had four dorsal longitudinal rows of small papillae; (2) Sphaerephesia was characterized by having four longitudinal rows of dorsal macrotubercles with terminal papillae; (3) Sphaerodoropsis, thought to be the most speciose, showed from four dorsal longitudinal rows of macrotubercles in a single, transverse, segmental row, to numerous dorsal longitudinal and transverse rows of 
tubercles (Figure 23b); and (4) Clavodorum and Sphaerodoridium showed six or more dorsal longitudinal rows of stalked macrotubercles [447].

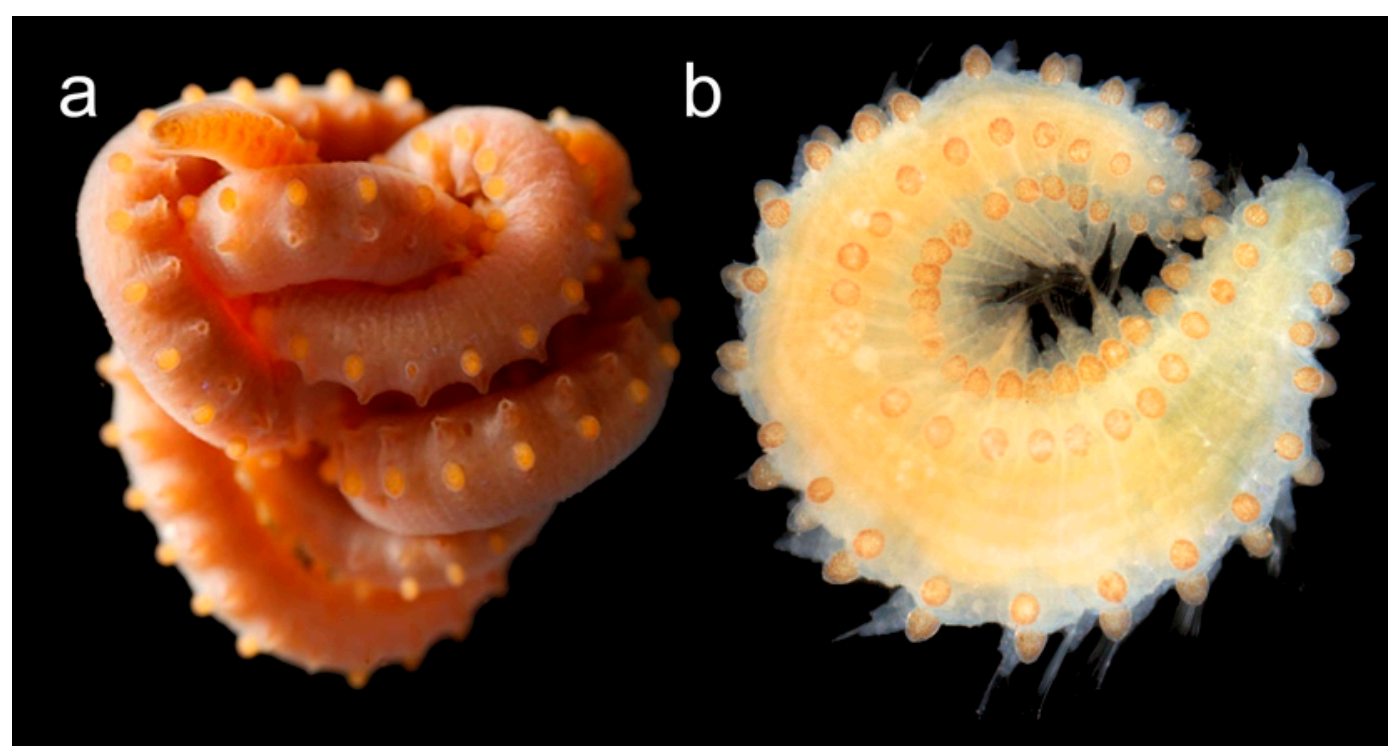

Figure 23. Sphaerodoridae. (a) Spaeherodorum sp. (b) Sphaerodoropsis cf. philippi (Fauvel, 1911) [464]. (Photos by A. Nygren).

Although still incomplete (i.e., representatives of some genera were missing), the new classification based on phylogenetic analyses of nuclear and mitochondrial DNA showed Sphaerodoropsis as being split in three major clades: (1) Sphaerodoropsis Group 1 sensu Borowski [466], should be synonymized with Sphaerephesia [453] to group all sphaerodorids with four longitudinal rows of sessile macrotubercles (regardless if they are smooth or with a terminal papilla, spherical or hemispherical) arranged in a single transverse row per segment; (2) Sphaerodoropsis Group 3 sensu Borowski [466] is characterized by having two transverse rows of sessile macrotubercles per segment, leading to the erection of Geminofilum [453]; and (3) Sphaerodoropsis Group 2 sensu Borowski [466] that has sessile macrotubercles arranged in more than six longitudinal rows (in a single transverse row per segment) was found nested with other sphaerodorids with stalked macrotubercles and a similar arrangement. Consequently, it was included in Sphaerodoridium. Finally, the species having exactly six rows of macrotubercles were recovered as a paraphyletic clade and left under Clavodorum.

Members of Sphaerodoropsis with small macrotubercles in three or more transverse rows per segment (Group 4 sensu Borowski [466]) were not included in the existing phylogenetic studies, neither were those sphaerodorids without large tubercles (i.e., Amacrodorum and Euritmia). However, since members of these two taxa shared the arrangement of epithelial papillae and the presence of only simple chaetae, Amacrodorum was synonymized under Euritmia [451].

Although the sphaerodorids have been reported as not common in benthic samples [467], some recent data also show their distribution is often patchy at shelf sediments and can actually be abundant $[453,468]$. In fact, they are exclusively benthic marine organisms, and are present in all oceans and at all depths. They are often reported from deep-sea sediments, but also occur in shallow waters, including hard substrates and algae (as epibionts) $[447,452,453,455,458,468-470]$, where they are often considered as members of the meiofauna $[471,472]$.

The number of species described at the different marine benthic zones has now been reviewed. The continental shelf (intertidal to ca. $200 \mathrm{~m}$ depth), with 61 species, is the richest benthic zone, although more than a half (i.e., 35) were described from shallow waters (<40 m depth). The bathyal zone (200-4000 m depth), with 48 species, and the abyssal (4000-6000 m depth) with 11, led a total of 59 deep sea species, almost as much as 
in shallower waters. Given that the continental shelf is better studied than the deep-sea, these numbers may confirm the deep-sea as more specious.

Most members of the family have been described from Atlantic waters, both Temperate Northern (31 species) and Tropical (18 species) realms sensu Spalding et al. [473], followed by the Southern Ocean (16 species), the Central Indo-Pacific (15 species) and the Arctic (13 species). The highest number of georeferenced occurrences [34] are also reported in the Northern Atlantic, the Southern Ocean, and the Arctic, which actually indicate that these areas are better studied than others worldwide. The Temperate Northern Pacific seems also to be well surveyed and show a high number of records [34], but does not hold a high number of species (one three were described in this area and a few others have been reported there). However, by considering georeferenced reports as a direct measure of how well surveyed an area is, the most surprising situation occurs in the Central IndoPacific, where several species have been recently described species, but the overall number of records is very low. Conversely, the Temperate South America, especially the northwestern coast, the Temperate South Africa and the Indo-Pacific (Eastern and Western) appear to be understudied, with(seven or less species described from these realms and few occurrences reported [34]. Thus, they would need to be prioritized in future surveys.

\subsubsection{Syllidae}

Syllidae is the largest polychaete family, comprising ca. 1100 species distributed in 79 genera [6]. Its intricate taxonomic history is reflected in a maze of doubtful, invalid, and synonymized names. The family Amytidea Grube, 1850 [119] was first proposed to include several genera that were later invalidated and recognized as reproductive forms (epitokes), mainly based on the pivotal work describing the reproductive cycle of Autolytus cornutus Agassiz, 1862 [474], today included in Proceraea Ehlers, 1864 [64]. The tribes Syllideae Grube, 1850 [119], Exogoneae Langerhans, 1879 [475], and Autolyteae Langerhans, 1879 [475] were then proposed to better accommodate the syllids [475], which were later complemented by adding the Eusylleae Malaquin, 1893 [476]. In fact, this work was the first large monograph on the family, where the author described new species, proposed new classifications and addressed numerous biological aspects [476]. In the 20th century, the tribes were raised to the subfamily level [201,477], a recognition still followed today, as Eusyllinae Malaquin, 1893 [476], Syllinae Grube, 1850 [119], Exogoninae Langerhans, 1879 [475], and Autolytinae Langerhans, 1879 [475] (Figures 24a-d and 25a-d). It was not until the 21th century that the fifth subfamily, the Anoplosyllinae Aguado \& San Martín, 2009 [478], was erected together with the publication of major works synthesizing the current knowledge on the family $[479,480]$.

The first undoubtful description of a syllid, Nereis armillaris O.F. Müller, 1771 [481], dates back to the 18th century using the then newly proposed Linnean classification. Today the species is allocated in Syllis Savigny in Lamarck, 1818 [68]. Like in this case, a first phase of syllids history was characterized by numerous animals (now syllids) being described within different genera [482]. In fact, most species lacked a rigorous taxonomic position, often with the descriptions only highlighting their similarity with Nereis Linnaeus, 1758 [62]. It was only as a result of a major review of Annelida [119] that the family was described, implicitly recognizing the consistency of the group formed by animals that had begun to be described less than 100 years before. Since then, the number of species never stopped to increase and there is a continuous dripping of new descriptions that has no traces of deceleration still to date (Figure 26a,b).

During the last decades, several phylogenetic analyses have been performed on Syllidae, with the pioneer dealing with the morphology of Typosyllis Langerhans, 1879 [475,483], reproductive modes and subfamilies based on morphology [484] and Autolytinae based on molecular data [485]. The two latter studies used a limited number of terminal taxa, but their results were overall corroborated by analyzing a large number of taxa based on morphological and molecular data [486,487]. Other studies focused on Autolytinae [488] or on Pionosyllis Malmgren, 1867 [86,489], but also on the systematics of the whole family 
including a higher number of terminal taxa and based on combining three molecular markers (18S, 16S and COI) and/or morphology [478,486,487,490]. The overall congruent results of these studies revealed the monophyly of Anoplosyllinae, Eusyllinae, Autolytinae, Exogoninae and Syllinae, and reorganized the Eusyllinae, while Anguillosyllis Day, 1963 [491], Amblyosyllis Grube, 1857 [295], and Perkinsyllis San Martín, López \& Aguado, 2009 [489] were considered independent genera. The evolution of certain morphological characters (e.g., the pharyngeal structures), as well as the reproductive modes, could be traced in the obtained phylogenies. Epigamy is the plesiomorphic condition, while schizogamy has appeared twice in Syllinae and in Autolytinae [484,486,487,492].

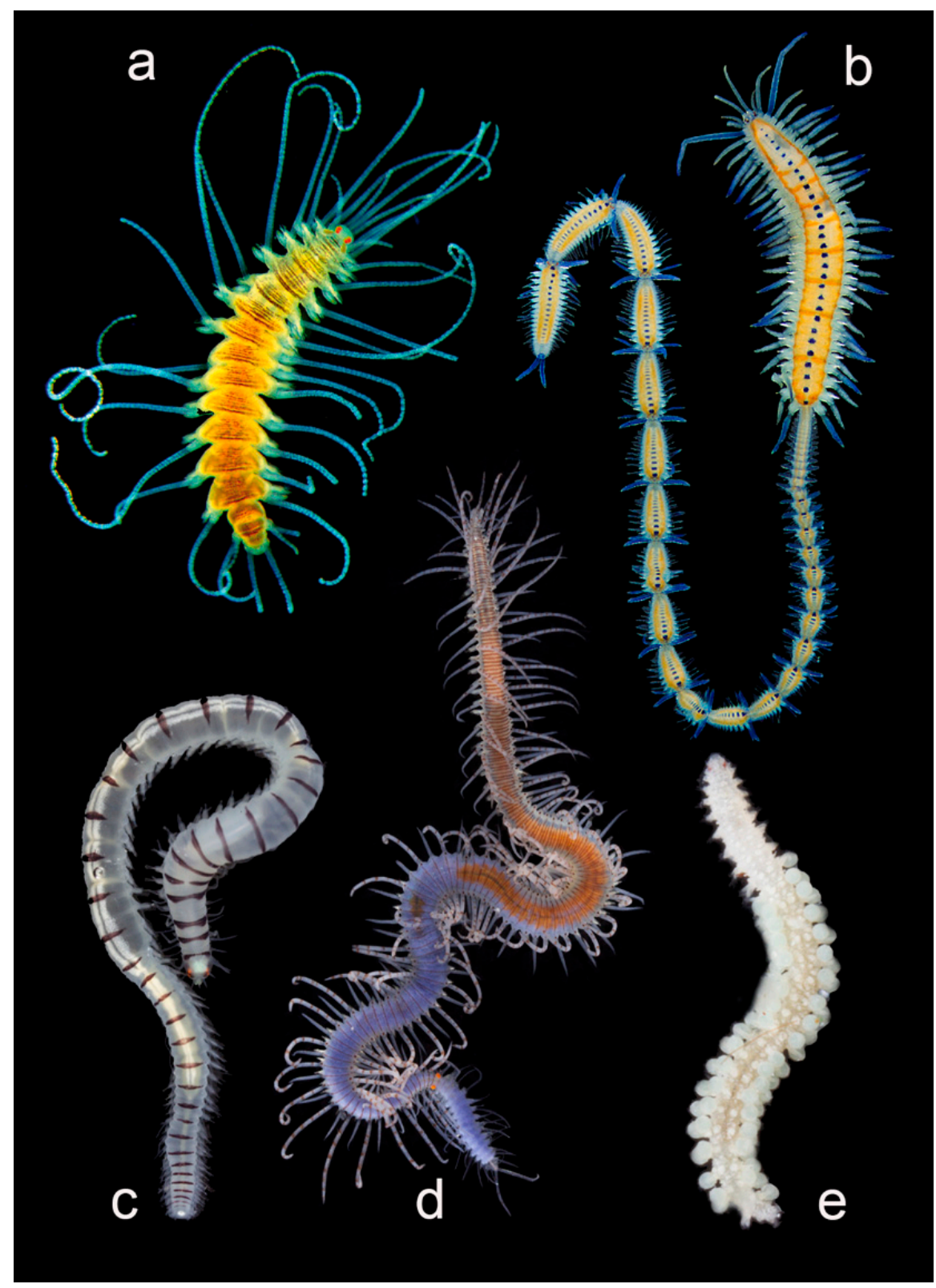

Figure 24. Syllidae. (a) Eusyllinae: Amblyosyllis anae Aguado, Capa, Lago-Barcia et al., 2019 [54]; photo by A. Nygren in [54]). (b) Autolytinae: Myrianida pachycera (Augener, 1913) [493]; photo by L. Harris. (c) Eusyllinae: Odontosyllis marombibooral San Martín \& Hutchings, 2006 [494]; photo by A. Semenov in Aguado et al. [495]. (d) Syllinae: Syllis maganda Martínez \& San Martín, 2020 [496]; photo by A. Semenov. (e) Exogoninae: Prosphaerosyllis longipapillata (Hartmann-Schröder, 1979) [497]; photo by A. Semenov in Aguado et al. [495]. 

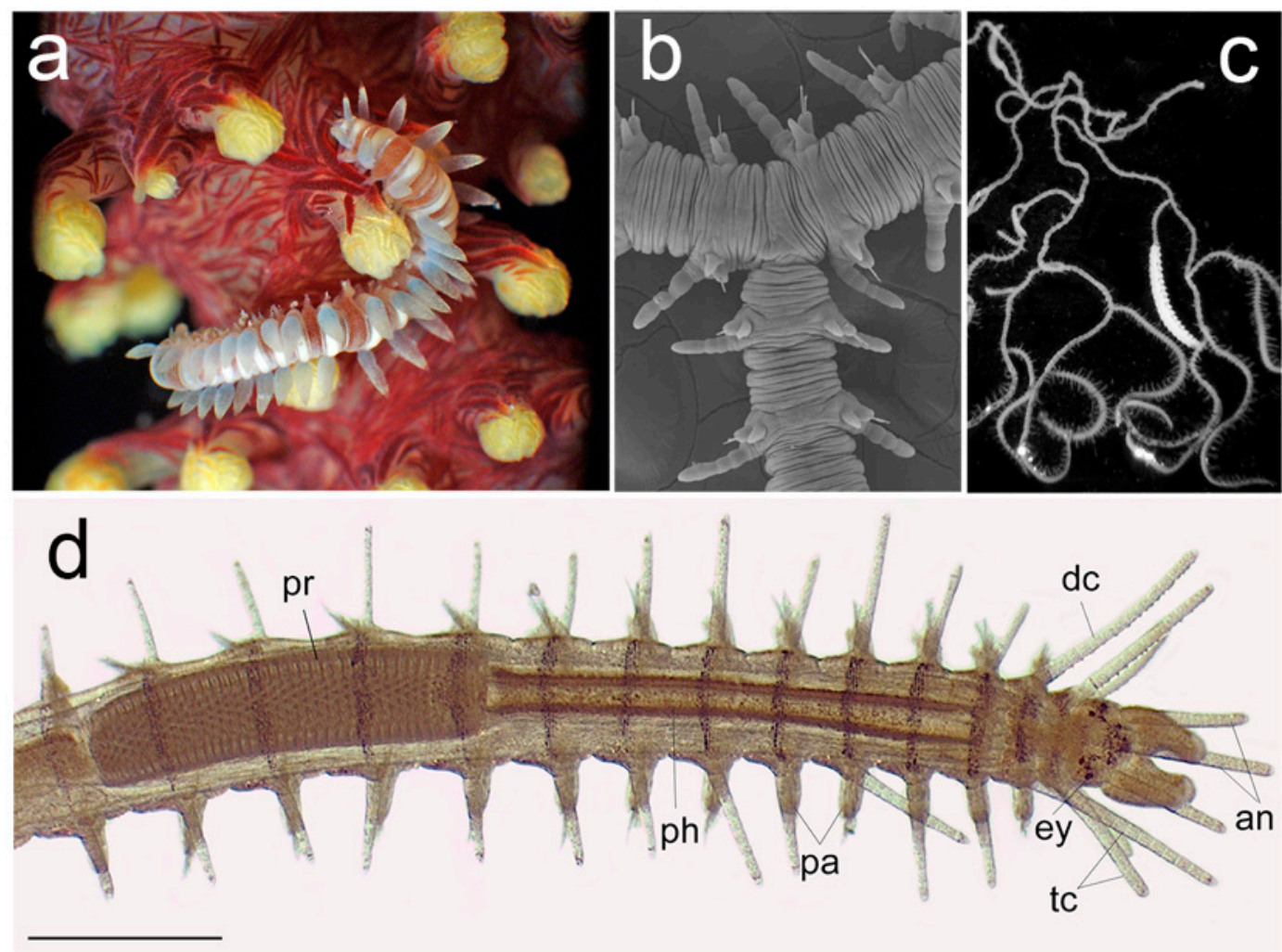

Figure 25. Syllidae. (a) Alcyonosyllis phili Glasby \& Watson, 2001 [498] on its alcyonacean host; photo by C. Glasby in [498]. (b) SEM of a Ramisyllis multicaudata Glasby, Schroeder and Aguado, 2012 [499] branching point. (c) Ramisyllis multicaudata, mid-posterior body showing terminal branches and developing female stolon, after [499]. (d) The anterior end of Syllis malaquini, Ribeiro, Ponz-Segrelles, Helm, Egger \& Aguado, 2020; photo by R. P Ribeiro in [500]; an: antenna, ey: eye, dc: dorsal cirrus, pa: parapodia, ph: pharynx, pl: palp, pr: proventricle, py: pygidium, tc: tentacular cirri.

The systematics of the family were corroborated by a phylogenetic analysis of complete mitochondrial genome, revealing also a high variability in the mitochondrial gene order, particularly in Syllinae [501]. Almost in parallel: (1) the existence of a 'ribbon-clade' lineage, which includes Ramisyllis Glasby, Schroeder \& Aguado, 2012 [499] and the flattened body syllids was proposed [492], and (2) Typosyllis and the previous division of the large genus Syllis in subgenera were proposed as non-valid [502]. Lastly, the monophyly of the family was supported based on all available sequences and markers, although subdivided in two different lineages: the 'ribbon-clade' (clade A) and clade B (including Syllis as paraphyletic genus) [500]. Accordingly, all hypotheses on the monophyly of the main groups within Syllidae (i.e., the five subfamilies and the main lineages within them) are highly congruent. This stable phylogenetic scenario allowed to trace the evolution of biological processes such as the reproductive modes and a large variety of regenerative abilities [500,503-505].

Syllidae is a complex family including large genera, such as Syllis [502,506] that is currently considered paraphyletic [500], together with very small taxa, with only few known species, or even only one $[507,508]$. The family includes species with a large diversity of morphologies (Figures 24a-e and 25a-c), from meiofaunal organisms with few chaetigers and less than $1 \mathrm{~mm}$ like in Neopetita San Martín, 2003 [479] and Erinaceusyllis San Martín, 2003 [479], to relatively large animals like in Trypanosyllis Claparède, 1864 [509], which may reach impressive lengths of $15 \mathrm{~cm}$ and hundreds of segments, or the even longer Syllis ramosa McIntosh, 1879 [510] and Ramisyllis multicaudata Glasby, Schroeder and Aguado, 2012 [499], which also show an unusual branched body pattern (Figure 25b,c). To some extent, species level identifications tend to be difficult, but the members of the family are relatively easily recognizable by the presence of the proventricle, a muscular, barrel-shaped structure associated to the pharynx [511] (Figure 25d). 

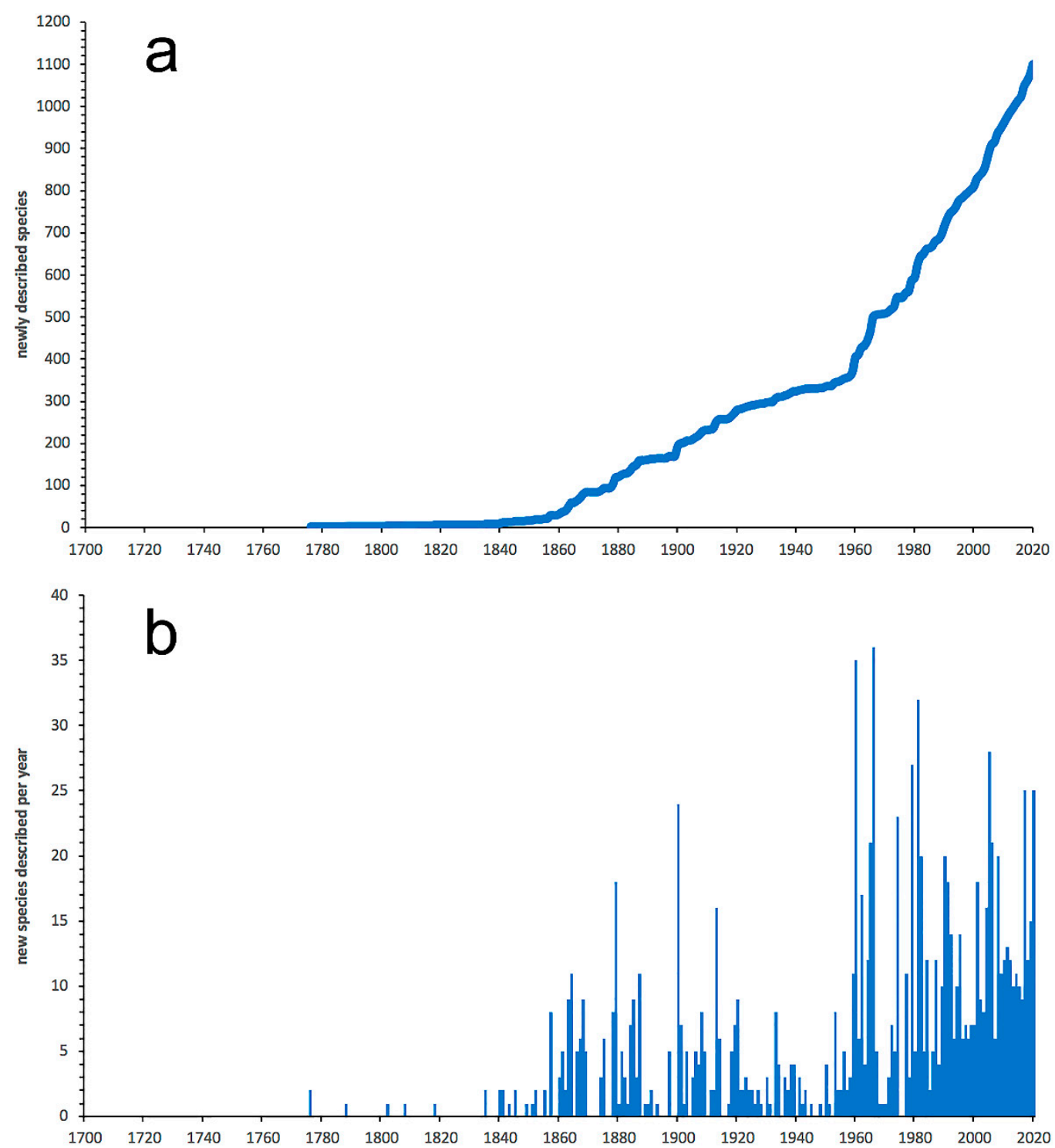

Figure 26. Syllidae. (a) Cumulative curve of newly described species through time. (b) The number of new species described per year.

Traditionally, species descriptions have been based on morphology, largely aided since the 1980s by detailed observations under scanning electron microscope [512]. Modern careful observations, complemented by molecular techniques, revealed the existence of numerous cryptic or pseudo-cryptic complexes sensu Nygren [18], hidden among the so-called "cosmopolitan" species [176], having very wide geographical distributions and bathymetric ranges $[54,58,513]$.

Members of the family can be found in great abundance and diversity in almost any marine environment, although they are slightly rarer at greater depths [479]. Their planktonic epitoke and benthic atoke forms occur in a wide range of habitats, including small interstitial forms inhabiting different types of soft sediments [513-516] to moderately large cryptofaunal forms [517-519] living in among boulders, coral reefs, sponges, algae, and mollusk banks, among others, from the mesolittoral and shallow intertidal to the deep sea.

Syllids present a worldwide distribution, but non-surprisingly showing a skewed pattern towards showing more occurrences in better studied regions [520], such as the Mediterranean, North Atlantic European and American coasts, Gulf of Mexico, and Aus- 
tralia. Instead of reflecting a likely true scenario, this rather 'Wallacean shortfall' [521], in the case of Syllidae, has been mitigated in the aforementioned areas by numerous contributions spanning from the 19th century to recent years. Among these, it is worth mentioning some large taxonomic efforts either concentrated on, or having the family as one of their focuses, in European waters [119,475,476,479,522], North American Atlantic coast [523], the Gulf of Mexico [524-529], and Australia [469,495,530-534].

Despite their nearly ubiquity in marine environments, syllids have been the subject of few biogeographic studies to date, most of them concentrated in the Mediterranean. A thorough account of the syllids from the Balearic Islands (Spain), found most species as having disjunct or Atlantic-Mediterranean distributions [522], a trend also found for the whole Mediterranean syllids [535,536], which allowed corroborating previous propositions of dividing the Mediterranean in northern and southern basins [537]. In a narrower cut, the fauna of Rovinj (Croatia, Northern Adriatic Sea) revealed numerous new records while pointing to a possible "meridionalization" of the region, which might be explained by global warming effects [538].

It is worth mentioning that syllids can be found in nearly all marine environments, being particularly abundant in rocky shore intertidal communities. This leads to the species being frequently identified by non-specialists and, non-rarely, based on outdated European keys (cf. [539]). Thorough revisions (e.g., [54,58,540,541] have already demonstrated that, in many instances, careful examinations may reveal a hidden diversity larger than previously thought, not only in poorly studied locations but also among "well-known" species. As already pointed out $[522,535,536,538]$, the lack of long-term taxonomical data in many regions, frequently with large knowledge voids, preclude more sound biogeographic conclusions, a fact that may help to explain the abovementioned lack of studies within the group.

Syllids present a wide range of feeding strategies, usually using a single tooth to graze, and/or a crown of denticles associated to the pharynx to punch on other animals. Food ingestion is assisted by a pumping action of the proventricle. Traditionally, Syllinae and Autolytinae are considered as carnivores, Eusyllinae omnivorous and Exogoninae selective deposit feeders and/or opportunistic carnivores [151,542,543]. However, this classification was a generalization based on a few cases, some of which were also based on assumptions by previous authors. A more mixed-up scenario proposed the species of Syllinae, Eusyllinae and Exogoninae to be herbivores, omnivores, and detritivores [544]. More recently, trophic guilds have been updated, but no clear subfamily-level trends have been proposed [12]. Instead, a rather omnivore habit has been postulated across the family, as indicated by the frequent findings of recognizable detritus (e.g., fragments of diatoms, forams, algae and copepods) in guts and fecal pellets of different species [12].

Members of the family are also often found living in symbiosis with many other organisms (Figure 24a-c), either as commensals of sponges, alcyonaceans, gorgonians, scleractinian corals, bryozoans, tunicates, asteroids, ophiuroids, and crustaceans, or (more rarely) as parasites of sponges, cnidarians, other polychaetes, crustaceans, and tunicates (see [16] and references therein) or as hosts, for instance of epibiotic ciliophoran protozoa [545] or an haplosporidian internal parasites [546]. In fact, they are the second most diverse polychaete family, after Polynoidae, in terms of symbiotic relationships [16]. Living animals, especially symbionts, frequently display camouflage colorings, which are usually easily lost in preserved material. The most widespread symbiotic association within the family probably occurs in Haplosyllis Langerhans, 1879 [475]. The so-called sponge-associated type species Haplosyllis spongicola Langerhans, 1879 [475] is in fact a specialized sponge predator whose distribution is restricted to European coasts, while all other reports of this species revealed to be numerous strictly sponge-symbiotic new species with locally-restricted distributions, e.g., [547,548]. Other interesting associations are those of Alcyonosyllis, which was named after its alcyonacean octocoral original hosts [498], although some species were later found living with gorgonians and hexacorals [549], and those of $S$. ramosa and R. multicaudata, whose complex branching bodies move inside 
the channels of their host sponges [492] (Figure 25a-c). Very likely, taking into account the great proportion of cryptic species within Syllidae, some of the symbionts currently accepted as being polyxenous could certainly be different species still requiring to be properly described.

\section{Conclusions}

1. The highest numbers of species of Phyllodocida have been reported from European, North American, and Australian waters, although these numbers are biased by an increased sampling effort in these regions and do not reflect true species richness. DNA barcode data show similar patterns, but also similar bias.

2. At the family level, the highest number of distribution records are for Nephtyidae, Phyllodocidae, Syllidae, Nereididae, and Polynoidae and widest distribution ranges were for Phyllodocidae, Polynoidae, Nereididae, Syllidae, and Lopadorrhynchidae.

3. Overall, there is a weak latitudinal gradient in species richness, with a rather uniformly high diversity across tropical and temperate latitudes and a drop only in extreme latitudes.

4. Antarctic and Pacific coasts of America and Asia, together with the circumtropical areas worldwide show the highest level of endemism, while the lowest numbers occur in temperate Atlantic areas and in the Arctic Ocean.

5. Most records of Phyllodocida and the highest species number and barcode data come from the high subtidal, where Nereididae, Syllidae, and Nephtyidae dominate. However, members of Phyllodocida seems to be well adapted to deep waters, particularly polynoids.

6. Less than $3 \%$ of the known species have been reported as occurring non-natively in certain parts of the world, most of them in Mediterranean waters, and more than half belong to Nereididae and Syllidae. However, many "non-native" or "introduced" species, particularly those belonging to critic species-complexes, turned to be native species with locally restricted populations when carefully examined. None of them has been considered as invasive or as pest to date.

7. There is a still unknown number of possible cryptic species complexes, this being a recurrent trend in most examined families.

8. Most examined families except to some extent Glyceridae and Goniadidae, show no traces of stabilization of the accumulative curve of species description, indicating that more new species are expected to be described in the coming years. Sources of new species diversity are mainly related with cryptic species complexes, but also with sampling in poorly explored regions and environments, with the deep-sea being particularly promising.

9. Only 620 species of Phyllodocida have sequences published in BOLD, for 1215 BINS as a consequence of having sequences (1) assigned to higher taxonomic ranks (genus or family), and (2) with wrong taxonomy assignments, the latter representing $22 \%$ and including sequences either misidentified and/or with invalid, misspelled, or synonymized names.

10. Our analyses show the key importance of keeping barcode libraries adequately curated, together with the need of adding metadata, while highlighting the apparent difficulty of having molecular data with correct identifications among Phyllodocida, with less than $60 \%$ of the records being usable at the species-level in statistical analysis.

11. Despite the amount of knowledge on the systematics of Phyllodocida, we would like to stress that there are still many open questions regarding the correct phylogenetic placement of most taxa (at different levels) so that further efforts must be dedicated to collecting new materials, allowing precise morphological descriptions in parallel with sequences.

12. We would like to highlight that there is a similar lack of knowledge with respect to the ecology of most species of Phyllodocida, as well as on their functional role in marine ecosystems all over the world oceans. 
13. Taking into account that we are entering in the 2020s Oceans Decade, during which marine ecosystems have to be re-evaluated from many different points of view (from basic science to sustainable ecosystem services and derived benefits), having a real and accurate picture of the world oceans emerges as a strategic pillar, with the knowledge on the diversity they hold being keystone.

Supplementary Materials: The following are available online at https: / / www.mdpi.com/1424-281 8/13/3/131/s1, Figure S1: Polynoidae. (a) Biogeographic diversity distribution showing the number of species/genera record. Polynoidae. (b) Number of records, (c) number of species and (d) expected number of species per $5^{\circ}$ of latitude, Figure S2: Polynoidae. Geographical distribution of two the most wide spread poly-noids: (a) Harmothoe imbricata and (b) Lepidonotus squamatus. Blrue circles: Data from OBIS; Greesn area: data from [351].

Author Contributions: Conceptualization: D.M., M.T.A., M.C.; methodology: M.A.L.T., S.F., D.M.; writing—sections, Analyses of Phyllodocida: S.F., M.A.L.T.; Glyceriformia: M.B.; Holoplanktonic families: M.-A.F.Á., M.A.V.P., C.H.; Nephtyidae: A.R.; Polynoidae: D.M., T.A.B.; Sphaerodoridae: M.C.; Syllidae: M.T.A., M.V.F.; writing—original draft: D.M.; writing-review and editing: D.M., M.T.A., M.-A.F.Á., T.A.B., M.B., M.C., S.F., M.V.F., C.H., M.A.V.P., A.R., M.A.L.T.; illustrations: D.M., M.T.A., M.-A.F.Á., T.A.B., M.B., M.C., S.F., M.V.F., C.H., M.A.V.P., A.R., M.A.L.T.; tables: S.F. All authors have read and agreed to the published version of the manuscript.

Funding: We acknowledge support of the publication fees by the CSIC Open Access Publication Support Initiative through its Unit of Information Resources for Research (URICI) and the Open Access Publication Funds of the Georg-August-Universität Göttingen. This research was funded by the Spanish "Agencia Estatal de Investigación" (AEI) and the European Funds for Regional Development (FEDER), Research Project PopCOmics (CTM2017-88080) to DM; the Russian Scientific Foundation for Basic Research, grant no. RFBR 18-05-00459 to TAB; Fundação para a Ciência e a Tecnologia (FCT), contract foreseen in the Decree-Law 57/2016 (Nrs 4-6, art. 23), changed by Law 57/2017 to AR and FCT/MCTES to CESAM (UIDP/50017/2020+UIDB/50017/2020) through national funds; São Paulo Research Foundation (FAPESP), fellowship proc. 2007/53040-9 to MVF; Spanish MINECO, AEI, Comunidad Autónoma de las Islas Baleares, European Social Funds and Ramón y Cajal program, RYC-2016-20799 to MC; FCT and ESF (SFRH/BD/131527/2017) through a PhD grant to MALT.

Data Availability Statement: All data used in this study have been made available on-line, and the corresponding links are indicated in the text.

Acknowledgments: The images of preserved holoplanktonic Phyllodocida have been provided by the Biological Collection "Edmundo F. Nonato" (ColBIO)-Oceanographic Institute, University of São Paulo, SP, Brazil, while those form living specimens have been provided by Xavi Salvador Costa. Some images of the Syllidae were taken by L. Harris, A. Nygren, A. Semenov, R. P. Ribeiro and C. Glasby, while some of Sphaerodoridae were taken by A. Nygren. The authors would like to thank the anonymous reviewers, who greatly appreciate our work and whose comment substantially contributed to increase the quality and readability of our paper.

Conflicts of Interest: The authors declare no conflict of interest. The funders had no role in the design of the study; in the collection, analyses, or interpretation of data; in the writing of the manuscript, or in the decision to publish the results.

\section{References}

1. Dales, R.P. The polychaete stomodeum and the inter-relationships of the families of Polychaeta. Proc. Zool. Soc. Lond. 1962, 139, 389-428. [CrossRef]

2. Rouse, G.W.; Fauchald, K. Cladistics and polychaetes. Zool. Scr. 1997, 26, 139-204. [CrossRef]

3. Rouse, G.W.; Pleijel, F. Polychaetes; Oxford University Press Inc.: New York, NY, USA, 2001.

4. Weigert, A.; Bleidorn, C. Current status of annelid phylogeny. Org. Divers. Evol. 2016, 16, 345-362. [CrossRef]

5. Struck, T.H.; Paul, C.; Hill, N.; Hartmann, S.; Hosel, C.; Kube, M.; Lieb, B.; Meyer, A.; Tiedemann, R.; Purschke, G.; et al. Phylogenomic analyses unravel annelid evolution. Nature 2011, 471, 95-98. [CrossRef] [PubMed]

6. Read, G.; Fauchald, K. World Polychaeta Database. 2020. Available online: http://www.marinespecies.org/polychaeta (accessed on 6 September 2020).

7. Parry, L.; Tanner, A.; Vinther, J. The origin of annelids. Palaeontology 2014, 57, 1091-1103. [CrossRef] 
8. Farrell, U.C.; Briggs, D.E. A pyritized polychaete from the Devonian of Ontario. Proc. R. Soc. B Biol. Sci. 2007, $274,499-504$. [CrossRef] [PubMed]

9. Gonzalez, B.C.; Martínez, A.; Borda, E.; Iliffe, T.M.; Eibye-Jacobsen, D.; Worsaae, K. Phylogeny and systematics of Aphroditiformia. Cladistics 2018, 34, 225-259. [CrossRef]

10. Parapar, J.; Caramelo, C.; Candás, M.; Cunha-Veira, X.; Moreira, J. An integrative approach to the anatomy of Syllis gracilis Grube, 1840 (Annelida) using micro-computed X-ray tomography. PeerJ 2019, 7, e7251. [CrossRef]

11. Watson, C.; Faulwetter, S. Stylet jaws of Chrysopetalidae (Annelida). J. Nat. Hist. 2017, 51, 2863-2924. [CrossRef]

12. Jumars, P.A.; Dorgan, K.M.; Lindsay, S.M. Diet of worms emended: An update of polychaete feeding guilds. Annu. Rev. Mar. Sci. 2015, 7, 497-520. [CrossRef] [PubMed]

13. $\mathrm{Wu}, \mathrm{X} . ; \mathrm{Zhan}, \mathrm{Z} . ; \mathrm{Xu}, \mathrm{K}$. Two new and two rarely known species of Branchinotogluma (Annelida: Polynoidae) from deep-sea hydrothermal vents of the Manus Back-Arc basin, with remarks on the diversity and biogeography of vent polynoids. Deep Sea Res. Part I Oceanogr. Res. Pap. 2019, 149, 103051. [CrossRef]

14. Zhang, Y.; Chen, C.; Qiu, J.-W. Sexually dimorphic scale worms (Annelida: Polynoidae) from hydrothermal vents in the Okinawa Trough: Two new species and two new sex morphs. Front. Mar. Sci. 2018, 5, 112. [CrossRef]

15. McCowin, M.F.; Rouse, G.W. Phylogeny of hydrothermal vent Iphionidae, with the description of a new species (Aphroditiformia, Annelida). ZooKeys 2018, 779, 89-107. [CrossRef] [PubMed]

16. Martin, D.; Britayev, T.A. Symbiotic polychaetes revisited: An update of the known species and relationships (1998-2017). Oceanogr. Mar. Biol. Annu. Rev. 2018, 56, 371-448. [CrossRef]

17. Martin, D.; Britayev, T.A. Symbiotic polychaetes: Review of known species. Oceanogr. Mar. Biol. Annu. Rev. 1998, 36, $217-340$.

18. Nygren, A. Cryptic polychaete diversity: A review. Zool. Scr. 2014, 43, 172-183. [CrossRef]

19. Ravara, A.; Ramos, D.; Teixeira, M.A.L.; Costa, F.O.; Cunha, M.R. Taxonomy, distribution and ecology of the order Phyllodocida (Annelida, Polychaeta) in deep-sea habitats around the Iberian margin. Deep Sea Res. Part II Top. Stud. Oceanogr. 2017, 137, 207-231. [CrossRef]

20. Borja, A.; Franco, J.; Pérez, V. A marine biotic index to establish the ecological quality of soft-bottom benthos within European estuarine and coastal environments. Mar. Pollut. Bull. 2000, 40, 1100-1114. [CrossRef]

21. Pennisi, E. DNA barcodes jump-start search for new species. Science 2019, 364, 920-921. [CrossRef] [PubMed]

22. Leese, F.; Bouchez, A.; Abarenkov, K.; Altermatt, F.; Borja, Á.; Bruce, K.; Ekrem, T.; Čiampor, F.; Čiamporová-Zat'ovičová, Z.; Costa, F.O.; et al. Chapter Two-Why We Need Sustainable Networks Bridging Countries, Disciplines, Cultures and Generations for Aquatic Biomonitoring 2.0: A Perspective Derived From the DNAqua-Net COST Action. Adv. Ecol. Res. 2018, 58, 63-99. [CrossRef]

23. Deiner, K.; Lopez, J.; Bourne, S.; Holman, L.; Seymour, M.; Grey, E.K.; Lacoursière, A.; Li, Y.; Renshaw, M.A.; Pfrender, M.E.; et al. Optimising the detection of marine taxonomic richness using environmental DNA metabarcoding: The effects of filter material, pore size and extraction method. Metabarcoding Metagenom. 2018, 2, e28963. [CrossRef]

24. Weigand, H.; Beermann, A.J.; Čiampor, F.; Costa, F.O.; Csabai, Z.; Duarte, S.; Geiger, M.F.; Grabowski, M.; Rimet, F.; Rulik, B.; et al. DNA barcode reference libraries for the monitoring of aquatic biota in Europe: Gap-analysis and recommendations for future work. Sci. Total Environ. 2019, 678, 499-524. [CrossRef] [PubMed]

25. Nygren, A.; Pleijel, F. From one to ten in a single stroke-resolving the European Eumida sanguinea (Phyllodocidae, Annelida) species complex. Mol. Phylogenet. Evol. 2011, 58, 132-141. [CrossRef]

26. Delić, T.; Trontelj, P.; Rendoš, M.; Fišer, C. The importance of naming cryptic species and the conservation of endemic subterranean amphipods. Sci. Rep. 2017, 7, 3391. [CrossRef] [PubMed]

27. Fišer, C.; Robinson, C.T.; Malard, F. Cryptic species as a window into the paradigm shift of the species concept. Mol. Ecol. 2018, 27, 613-635. [CrossRef]

28. Ratnasingham, S.; Hebert, P.D.N. Barcoding: Bold: The Barcode of Life Data System (http:/ /www.barcodinglife.org). Mol. Ecol. Notes 2007, 7, 335-345. [CrossRef]

29. Horton, T.; Kroh, A.; Ahyong, S.; Bailly, N.; Boyko, C.B.; Brandão, S.N.; Gofas, S.; Hooper, J.N.A.; Hernandez, F.; Holovachov, O.; et al. World Register of Marine Species (WoRMS). 2021. Available online: http:/ /www.marinespecies.org (accessed on 7 January 2021).

30. Chamberlain, S. Worrms: World Register of Marine Species (WoRMS) Client. R Package Version 0.4.0. 2019. Available online: https: / /CRAN.R-project.org/package=worrms (accessed on 20 April 2020).

31. R Core Team. R: A Language and Environment for Statistical Computing; R Core Team: Vienna, Austria, 2013. Available online: https:/ / www.R-project.org/ (accessed on 20 April 2020).

32. OBIS. Ocean Biodiversity Information System. Intergovernmental Oceanographic Commission of UNESCO. 2020. Available online: http: / / www.iobis.org (accessed on 20 April 2020).

33. Provoost, P.; Bosch, S. "Robis: R Client to access data from the OBIS API." Ocean Biogeographic Information System. Intergovernmental Oceanographic Commission of UNESCO. R Package Version 2.1.8. 2020. Available online: https://cran.r-project.org/ package $=$ robis (accessed on 20 April 2020).

34. "GBIF.org". GBIF Occurrence Download. 2020. Available online: https://doi.org/10.15468/dl.yntzgf (accessed on 20 April 2020). 
35. Provoost, P.; Bosch, S. “Obistools: Tools for Data Enhancement and Quality Control." Ocean Biogeographic Information System. Intergovernmental Oceanographic Commission of UNESCO. R Package Version 0.0.9. 2020. Available online: https: // cran.r-project.org/package=obistools (accessed on 20 April 2020).

36. Costello, M.J.; Tsai, P.; Wong, P.S.; Cheung, A.K.L.; Basher, Z.; Chaudhary, C. Marine biogeographic realms and species endemicity. Nat. Commun. 2017, 8, 1057. [CrossRef]

37. Barnes, R. DggridR: Discrete Global Grids. R Package Version 2.0.4. 2020. Available online: https://github.com/r-barnes/ dggridR/ (accessed on 20 April 2020).

38. Hurlbert, S.H. The nonconcept of species diversity: A critique and alternative parameters. Ecology 1971, 52, 577-586. [CrossRef] [PubMed]

39. Ahyong, S.; Costello, M.J.; Galil, B.S.; Gollasch, S.; Hutchings, P.A.; Katsanevakis, S.; Lejeusne, C.; Marchini, A.; Occhipinti, A.; Pagad, S.; et al. World Register of Introduced Marine Species (WRiMS). 2020. Available online: http:/ /www.marinespecies.org/ introduced (accessed on 6 September 2020). [CrossRef]

40. Çinar, M.E. Alien polychaete species worldwide: Current status and their impacts. J. Mar. Biol. Assoc. UK 2013, 93, 1257-1278. [CrossRef]

41. Faulwetter, S.; Simboura, N.; Katsiaras, N.; Chatzigeorgiou, G.; Arvanitidis, C. Polychaetes of Greece: An updated and annotated checklist. Biodivers. Data J. 2017, 5, e20997. [CrossRef] [PubMed]

42. Keppel, E.; Keith, I.; Ruiz, G.M.; Carlton, J.T. New records of native and non-indigenous polychaetes (Annelida: Polychaeta) in the Galapagos Islands. Aquat. Invasions 2019, 14, 59-84. [CrossRef]

43. Keppel, E.; Tovar-Hernandez, A.M.; Ruiz, G. First record and establishment of Branchiomma coheni (Polychaeta: Sabellidae) in the Atlantic Ocean and review of non-indigenous species of the genus. Zootaxa 2015, 4058, 499-518. [CrossRef] [PubMed]

44. Langeneck, J.; Lezzi, M.; Del Pasqua, M.; Musco, L.; Gambi, M.C.; Castelli, A.; Giangrande, A. Non-indigenous polychaetes along the coasts of Italy: A critical review. Mediterr. Mar. Sci. 2020, 238-275. [CrossRef]

45. López, E.; Richter, A. Non-indigenous species (NIS) of polychaetes (Annelida: Polychaeta) from the Atlantic and Mediterranean coasts of the Iberian Peninsula: An annotated checklist. Helgol. Mar. Res. 2017, 71, 19-36. [CrossRef]

46. Flanders Marine Institute. MarineRegions.org. 2020. Available online: www.marineregions.org (accessed on 1 November 2020).

47. Olenin, S.; Alemany, F.; Cardoso, A.C.; Gollasch, S.; Goulletquer, P.; Lehtiniemi, M.; McCollin, T.; Minchin, D.; Miossec, L.; Occhipinti-Ambrogi, A.O.H.; et al. Marine Strategy Framework Directive-Task Group 2 Report. Non-Indigenous Species; Office for Official Publications of the European Communities, EU/ICES: Luxembourg, 2010. [CrossRef]

48. Ravara, A.; Carvalho, S. Nephtyidae (Polychaeta, Phyllodocida) from the Red Sea, with record of a new species. J. Mar. Biol. Assoc. UK 2017, 97, 843-856. [CrossRef]

49. Carr, C.M.; Hardy, S.M.; Brown, T.M.; Macdonald, T.A.; Hebert, P.D.N. A tri-oceanic perspective: DNA barcoding reveals geographic structure and cryptic diversity in Canadian polychaetes. PLoS ONE 2011, 6, e22232. [CrossRef]

50. Reish, D.J.; Anderson, F.E.; Horn, K.M.; Hardege, J. Molecular phylogenetics of the Neanthes acuminata (Annelida: Nereididae) species complex. Mem. Mus. Vic. 2014, 71, 271-278. [CrossRef]

51. Fauvel, P. Mission Robert Ph. Dollfus en Egypte. Annélides Polychètes. Mémoires Présentes A L'institut D'egypte Et Publes Sous Les Auspices De Sa Majesté Fouad Ierroi D'egypte 1933, 21, 31-83.

52. Wehe, T. Revision of the scale worms (Polychaeta: Aphroditoidea) occurring in the seas surrounding the Arabian Peninsula. Part I: Polynoidae. Fauna Arab. 2006, 22, 23-197.

53. Hanley, J.R.; Burke, M. Scaleworms (Polychaeta: Polynoidae) of Albany, Western Australia. In Proceedings of the Third International Marine Biological Workshop: The Marine Fauna of Albany, Western Australia; Wells, F.E., Walker, D.I., Kirkman, H., Lethbridge, R., Eds.; Western Australian Museum: Perth, Australia, 1990; Volume I, pp. 203-236.

54. Aguado, M.T.; Capa, M.; Lago-Barcia, D.; Gil, J.; Pleijel, F.; Nygren, A. Species delimitation in Amblyosyllis (Annelida, Syllidae). PLoS ONE 2019, 14, e0214211. [CrossRef]

55. Michel, A. Sur les divers types de stolons chez les syllidiens, specialement sur une nouvelle espèce (Syllis cirropunctata n.sp.) à stolons acephales et sur la reobservation du stolon tetracère de Syllis amica Qfg. C. R. L'acad. Sci. Paris 1909, 148, 318-320.

56. Gravier, C. Contribution à l'étude des Annélides Polychètes de la Mer Rouge. Première partie. Nouv. Arch. Mus. D'hist. Nat. Paris $1900,2,137-282$.

57. Aguado, M.T.; San Martín, G. Syllidae (Polychaeta) from Lebanon with two new reports for the Mediterranean Sea. Cah. Biol. Mar. 2007, 48, 207-224.

58. Álvarez-Campos, P.; Giribet, G.; Riesgo, A. The Syllis gracilis species complex: A molecular approach to a difficult taxonomic problem (Annelida, Syllidae). Mol. Phylogenet. Evol. 2017, 109, 138-150. [CrossRef] [PubMed]

59. Leite, B.; Vieira, P.; Teixeira, M.; Lobo-Arteaga, J.; Hollatz, C.; Borges, L.; Duarte, S.; Troncoso, J.; Costa, F. Gap-analysis and annotated reference library for supporting macroinvertebrate metabarcoding in Atlantic Iberia. Reg. Stud. Mar. Sci. 2020, 101307. [CrossRef]

60. Duarte, S.; Vieira, P.E.; Costa, F.O. Assessment of species gaps in DNA barcode libraries of non-indigenous species (NIS) occurring in European coastal regions. Metabarc. Metagen. 2020, 4, e55162. [CrossRef]

61. Pamungkas, J.; Glasby, C.J.; Read, G.B.; Wilson, S.P.; Costello, M.J. Progress and perspectives in the discovery of polychaete worms (Annelida) of the world. Helgol. Mar. Res. 2019, 73, 4. [CrossRef] 
62. Linnaeus, C. Systema Naturae per Regna Tria Naturae, Secundum Classes, Ordines, Genera, Species, cum Characteribus, Differentiis, Synonymis, Locis. Tomus I. Editio Decima, Reformata; Laurentii Salvii: Stockholm, Sweden, 1758; p. 824.

63. Barrelier, J. Icones Plantarum per Galliam, Hispaniam et Italiam Observatur ad Vivum Exivitarum; Opus Posthumum Editum Cura et Studio Antonii de Jussieu: Paris, France, 1714; p. 148.

64. Ehlers, E. Die Borstenwürmer (Annelida Chaetopoda) nach Systematischen und Anatomischen Untersuchungen Dargestellt; Wilhelm Engelmann: Leipzig, Germany, 1864; Volume I, pp. 1-268.

65. Ehlers, E. Die Borstenwürmer (Annelida Chaetopoda) nach Systematischen und Anatomischen Untersuchungen Dargestellt; Wilhelm Engelmann: Leipzig, Germany, 1868; Volume II, pp. 269-748. [CrossRef]

66. Claparède, É. Les Annélides Chétopodes du Golfe de Naples. Mém. Soc. Phys. Hist. Nat. Genève 1868, 19, 313-584.

67. Claparède, É. Les annélides chétopodes du Golfe de Naples. Supplément. Mém. Soc. Phys. Hist. Nat. Genève 1870, $20,365-542$.

68. Lamarck, J.B. Histoire Naturelle des Animaux sans Vertèbres, Présentant les Caractères Généraux et Particuliers de ces Animaux, Leur Distribution, Leurs Classes, Leurs Familles, Leurs Genres, et la Citation des Principales Espèces qui s'y Rapportent; Précédée d'une Introduction Offrant la Détermination des Caractères Essentiels de l'Animal, sa Distinction du Végétal et des Autres Corps Naturels, Enfin, L'exposition des Principes Fondamentaux de la Zoologie. Vol. 5; Déterville \& Verdière: Paris, France, 1818; Volume 5, p. 612.

69. Müller, O.F. Zoologicae Danicae Prodromus, seu Animalium Daniae et Norvegiae Indigenarum Characteres, Nomina et Synonyma Imprimis Popularium; Hallageriis: Copenhagen, Denmark, 1776; p. 282. [CrossRef]

70. Fabricius, O. Fauna Groenlandica, Systematice Sistens, Animalia Groenlandiae Occidentalis Hactenus Indagata, Quoad Nomen Specificum, Triviale, Vernaculumque Synonyma Auctorum Plurium, Descriptionem, Locum, Victum, Generationem, Mores, Usum, Capturamque Singuli Prout Detegendi Occasio Fuit, Maximaque Parte Secundum Proprias Observationes; Impensis Ioannis Gottlob Rothe: Copenhagen, Denmark; Leipzig, Germany, 1780; p. 452.

71. Örsted, A.S. Annulatorum Danicorum Conspectus. Fasc. 1 Maricolae; Librariae Wahlianae: Hafniae, Denmark, 1843 ; p. 52.

72. Greeff, R. Über pelagische Anneliden von der Küste der canarischen Inseln. Z. Wiss. Zool. 1879, 32, $237-284$.

73. Steenstrup, J.S. Af Slaegten Tomopteris. Vidensk. Medd. Dan. Nat. Foren. I Köbenhavn 1850, 1850, 75-77.

74. Busch, W. Beobachtungen ueber Anatomie und Entwicklung Einiger Wirbellosen Seethiere; Aug. Hirschwald: Berlin, Germany, 1851; p. 143.

75. Linnaeus, C. Systema Naturae per Regna Tria Naturae, Editio Duodecima, Reformata, Tomus I, Pars II. Regnum Animale; Laurentii Salvii: Stockholm, Sweden, 1767.

76. Arfianti, T.; Costello, M.J. Global biogeography of marine amphipod crustaceans: Latitude, regionalization, and beta diversity. Mar. Ecol. Prog. Ser. 2020, 638, 83-94. [CrossRef]

77. Chaudhary, C.; Saeedi, H.; Costello, M.J. Marine species richness is bimodal with latitude: A reply to Fernandez and Marques. Trends Ecol. Evol. 2017, 32, 234-237. [CrossRef] [PubMed]

78. Hillebrand, H. Strength, slope and variability of marine latitudinal gradients. Mar. Ecol. Prog. Ser. 2004, 273, 251-267. [CrossRef]

79. Pamungkas, J.; Glasby, C.J.; Costello, M.J. Biogeography of polychaete worms (Annelida) of the world. Mar. Ecol. Prog. Ser. 2021, 657, 147-159. [CrossRef]

80. Chaudhary, C.; Saeedi, H.; Costello, M.J. Bimodality of latitudinal gradients in marine species richness. Trends Ecol. Evol. 2016, 31, 670-676. [CrossRef]

81. Webb, T.J.; Berghe, E.V.; O’Dor, R. Biodiversity's big wet secret: The global distribution of marine biological records reveals chronic under-exploration of the deep pelagic ocean. PLoS ONE 2010, 5, e10223. [CrossRef] [PubMed]

82. Izuka, A. The errantiate Polychaeta of Japan. J. Coll. Sci. Imp. Univ. Tokyo 1912, 30, 1-262.

83. Pernet, B. Benthic egg masses and larval development of Amblyosyllis speciosa (Polychaeta: Syllidae). J. Mar. Biol. Assoc. UK 1998, 78, 1369-1372. [CrossRef]

84. Okada, Y.K. Amblyosyllis nigrolineata, une nouvelle variété de l'A. speciosa Izuka. Annot. Zool. Jpn. 1934, 14, 317-320.

85. Imajima, M.; Hartman, O. The Polychaetous Annelids from Japan. Pt. I. Allan Hancock Found. Spec. Publ. 1964, $26,1-237$.

86. Malmgren, A.J. Annulata Polychaeta Spetsbergiae, Groelanlandiae, Islandiae et Scandinaviae Hactenus Cognita. Cum XIV. Tabulis; Ex Officina Frenckelliana: Helsinki, Finland, 1867; p. 127.

87. Langerhans, P. Die Wurmfauna von Madeira. III. Z. Wiss. Zool. 1880, 34, 87-143.

88. McIntosh, W.C. Report on the Annelida Polychaeta collected by the H.M.S. Challenger during the years 1873-1876. Rep. Sci. Res. Voy. H.M.S. Chall. 1872-76 1885, 12, 1-554.

89. Johnston, G. Miscellanea Zoologica. [Continued from vol. iv. p. 375.] Contributions towards a history of Irish Annelids (1). Ann. Mag. Nat. Hist. 1840, 5, 168-179. [CrossRef]

90. Teixeira, M.A.L.; Vieira, P.E.; Pleijel, F.; Sampieri, B.R.; Ravara, A.; Costa, F.O.; Nygren, A. Molecular and morphometric analyses identify new lineages within a large Eumida (Annelida) species complex. Zool. Scr. 2020, 49, 222-235. [CrossRef]

91. Vieira, P.E.; Desiderato, A.; Holdich, D.M.; Soares, P.; Creer, S.; Carvalho, G.R.; Costa, F.O.; Queiroga, H. Deep segregation in the open ocean: Macaronesia as an evolutionary hotspot for low dispersal marine invertebrates. Mol. Ecol. 2019, 28, 1784-1800. [CrossRef]

92. Brasier, M.J.; Wiklund, H.; Neal, L.; Jeffreys, R.; Linse, K.; Ruhl, H.; Glover, A.G. DNA barcoding uncovers cryptic diversity in 50\% of deep-sea Antarctic polychaetes. R. Soc. Open Sci. 2016, 3, 160432. [CrossRef] 
93. Nygren, A.; Parapar, J.; Pons, J.n.; Meißner, K.; Bakken, T.; Kongsrud, J.A.; Oug, E.; Gaeva, D.; Sikorski, A.; Johansen, R.A.; et al. A mega-cryptic species complex hidden among one of the most common annelids in the North East Atlantic. PLoS ONE 2018, 13, e0198356. [CrossRef]

94. Baird, W. Descriptions of several new species of worms belonging to the Annelida Errantia and Sedentaria or Tubicola of Milne Edwards. Proc. Zool. Soc. Lond. 1863, 1863, 106-110.

95. Watson, C. Revision of the pantropical genus Treptopale (Annelida: Phyllodocida: Chrysopetalidae): Redescription of Treptopale rudolphi Perkins, 1985 and description of two new species including comparison of Treptopale populations in northern Australia. Beagle Rec. Mus. Art Gall. North. Territ. 2010, 26, 37-55.

96. Gravier, C. Contribution à l'étude des Annélides Polychètes de la Mer Rouge (Suite). Bull. Mus. D'hist. Nat. Paris 1899, 6, 288-298.

97. Grube, A.E. Actinien, Echinodermen und Wurmen des Adriatischen und Mittelmeers nach Eigenen Sammlungen Beschrieben; J. H. Bon: Königsberg, Russia, 1840; p. 92. [CrossRef]

98. Langeneck, J.; Scarpa, F.; Maltagliati, F.; Sanna, D.; Barbieri, M.; Cossu, P.; Mikac, B.; Curini Galletti, M.; Castelli, A.; Casu, M. A complex species complex: The controversial role of ecology and biogeography in the evolutionary history of Syllis gracilis Grube, 1840 (Annelida, Syllidae). J. Zool. Syst. Evol. Res. 2020, 58, 67-78. [CrossRef]

99. Lobo, J.; Teixeira, M.A.L.; Borges, L.M.S.; Ferreira, M.S.G.; Hollatz, C.; Gomes, P.T.; Sousa, R.; Ravara, A.; Costa, M.H.; Costa, F.O. Starting a DNA barcode reference library for shallow water polychaetes from the southern European Atlantic coast. Mol. Ecol. Resour. 2016, 16, 298-313. [CrossRef] [PubMed]

100. Audzijonyte, A.; Ovcarenko, I.; Bastrop, R.; Vainola, R. Two cryptic species of the Hediste diversicolor group (Polychaeta, Nereididae) in the Baltic Sea, with mitochondrial signatures of different population histories. Mar. Biol. 2008, 155, 599-612. [CrossRef]

101. Virgilio, M.; Fauvelot, C.; Costantini, F.; Abbiati, M.; Backeljau, T. Phylogeography of the common ragworm Hediste diversicolor (Polychaeta: Nereididae) reveals cryptic diversity and multiple colonization events across its distribution. Mol. Ecol. 2009, 18, 1980-1994. [CrossRef] [PubMed]

102. Sato, M.; Nakashima, A. A review of Asian Hediste species complex (Nereididae, Polychaeta) with descriptiuons of two new species and a redescription of Hediste japonica (Izuka,1908). Zool. J. Linn. Soc. Lond. 2003, 137, 203-445. [CrossRef]

103. Tosuji, H.; Bastrop, R.; Götting, M.; Park, T.; Hong, J.-S.; Sato, M. Worldwide molecular phylogeny of common estuarine polychaetes of the genus Hediste (Annelida: Nereididae), with special reference to interspecific common haplotypes found in southern Japan. Mar. Biodivers. 2019, 49, 1385-1402. [CrossRef]

104. Fujita, M.K.; Leaché, A.D.; Burbrink, F.T.; McGuire, J.A.; Moritz, C. Coalescent-based species delimitation in an integrative taxonomy. Trends Ecol. Evol. 2012, 27, 480-488. [CrossRef]

105. Fontaneto, D.; Flot, J.-F.; Tang, C.Q. Guidelines for DNA taxonomy, with a focus on the meiofauna. Mar. Biodivers. 2015, 45, 433-451. [CrossRef]

106. Lindgren, J.; Hatch, A.S.; Hourdez, S.; Seid, C.A.; Rouse, G.W. Phylogeny and biogeography of Branchipolynoe (Polynoidae, Phyllodocida, Aciculata, Annelida), with descriptions of five new species from methane seeps and hydrothermal vents. Diversity 2019, 11, 153. [CrossRef]

107. Gastaldi, A. Harmothoe Imbricata: Species Complex or Complex Species? University of Alaska Fairbanks: Fairbanks, AK, USA, 2019.

108. Álvarez-Campos, P.; Giribet, G.; San Martín, G.; Rouse, G.W.; Riesgo, A. Straightening the striped chaos: Systematics and evolution of Trypanosyllis and the case of its pseudocryptic type species Trypanosyllis krohnii (Annelida, Syllidae). Zool. J. Linn. Soc. 2017, 179, 492-540. [CrossRef]

109. Fontes, J.T.; Vieira, P.E.; Ekrem, T.; Soares, P.; Costa, F.O. BAGS: An automated Barcode, Audit \& Grade System for DNA barcode reference libraries. Mol. Ecol. Resour. 2021, 21, 573-583. [CrossRef] [PubMed]

110. Hartmann-Schröder, G. Annelida, Borstenwürmer, Polychaeta. Tierwelt Dtschl. 1971, 58, 1-594.

111. Kinberg, J.G.H. Nya slägten och arter af Annelider. Öfvers. Kongliga Vetensk. Akad. Förhandlingarstockholm 1856, 12, 381-388.

112. Schmarda, L.K. Neue wirbellose Thiere Beobachtet und Gesammelt auf Einer Reise un Die Erdr 1853 bis 1857. Erster Band (Zweite Halfte) Turbellarian, Rotatorien un Anneliden; Wilhelm Engelmann: Leipzig, Germany, 1861; p. 164.

113. Webster, H.E.; Benedict, J.E. The Annelida Chaetopoda, from Eastport, Maine. Annu. Rep. United States Comm. Fish Fish. 1887, 12, 707-758.

114. Bergsten, J.; Bilton, D.T.; Fujisawa, T.; Elliott, M.; Monaghan, M.T.; Balke, M.; Hendrich, L.; Geijer, J.; Herrmann, J.; Foster, G.N.; et al. The effect of geographical scale of sampling on DNA barcoding. Syst. Biol. 2012, 61, 851-869. [CrossRef] [PubMed]

115. Cariani, A.; Messinetti, S.; Ferrari, A.; Arculeo, M.; Bonello, J.J.; Bonnici, L.; Cannas, R.; Carbonara, P.; Cau, A.; Charilaou, C.; et al. Improving the Conservation of Mediterranean Chondrichthyans: The ELASMOMED DNA Barcode Reference Library. PLoS ONE 2017, 12, e0170244. [CrossRef]

116. Oliveira, L.M.; Knebelsberger, T.; Landi, M.; Soares, P.; Raupach, M.J.; Costa, F.O. Assembling and auditing a comprehensive DNA barcode reference library for European marine fishes. J. Fish Biol. 2016, 89, 2741-2754. [CrossRef]

117. Costa, F.O.; Landi, M.; Martins, R.; Costa, M.H.; Costa, M.E.; Carneiro, M.; Alves, M.J.; Steinke, D.; Carvalho, G.R. A ranking system for reference libraries of DNA barcodes: Application to marine fish species from Portugal. PLoS ONE 2012, 7, e35858. [CrossRef]

118. Fauchald, K. The polychaete worms. Definitions and keys to the orders, families and genera. Nat. Hist. Mus. Los Angel. County. Sci. Ser. 1977, 28, 1-188. 
119. Grube, A.E. Die Familien der Anneliden. Arch. Nat. Berl. 1850, 16, 249-364.

120. Kinberg, J.G.H. Annulata nova. Öfvers. Kongliga Vetensk. Akad. Förhandlingarstockholm 1865, 21, 559-574.

121. Böggemann, M. Revision of the Glyceridae Grübe 1850 (Annelida: Polychaeta). Abh. Senckenbergischen Nat. Ges. 2002, 555, 1-249.

122. Böggemann, M. Revision of the Goniadidae (Annelida, Polychaeta). Abh. Nat. Ver. Hambg. (Neue Folgen) 2005, $39,1-354$.

123. Böggemann, M. Worms that might be 300 million years old. Mar. Biol. Res. 2006, 2, 130-135. [CrossRef]

124. Böggemann, M. Polychaetes (Annelida) of the abyssal SE Atlantic. Org. Divers. Evol. 2009, 9, 251-428. [CrossRef]

125. Richter, S.; Schwarz, F.; Hering, L.; Böggemann, M.; Bleidorn, C. The utility of genome skimming for phylogenomic analyses as demonstrated for glycerid relationships (Annelida, Glyceridae). Genome Biol. Evol. 2015, 7, 3443-3462. [CrossRef]

126. Rousset, V.; Pleijel, F.; Rouse, G.W.; Erseus, C.; Siddall, M.E. A molecular phylogeny of annelids. Cladistics 2007, 23, 41-63. [CrossRef]

127. Böggemann, M. Chapter 7.11.8 Glyceridae Grube, 1850. In Handbook of Zoology Online; Westheide, W., Purschke, G., Böggemann, M., Eds.; De Gruyter: Berlin, Germany, 2014.

128. Böggemann, M. Chapter 7.11.9 Goniadidae Kinberg, 1865. In Handbook of Zoology Online; Westheide, W., Purschke, G., Böggemann, M., Eds.; De Gruyter: Berlin, Germany, 2014.

129. Imajima, M. Polychaetous Annelids from Sagami Bay and Sagami Sea Collected by the Emperor Showa of Japan and Deposited at the Showa Memorial Institute, National Science Museum, Tokyo (II): Orders included within the Phyllodocida, Amphinomida, Spintherida and Eunicida. Natl. Sci. Mus. Monogr. 2003, 23, 1-221.

130. Barrett, B.M.; Bailey-Brock, J.H. Progoniada oahuensis, a new species from Oahu, Hawaii (Annelida: Polychaeta: Goniadidae). Proc. Biol. Soc. Wash. 2005, 118, 251-258. [CrossRef]

131. Böggemann, M.; Orensanz, J.M. Glyceriformia Fauchald, 1977 (Annelida:"Polychaeta") from the SW Atlantic Shelf, between $30^{\circ}$ and $45^{\circ}$ S. Mitt. Aus Dem Hambg. Zool. Mus. Und Inst. 2007, 104, 11-59.

132. Rizzo, A.E.; Steiner, T.M.; Amaral, A.C.Z. Glyceridae Grube 1850 (Annelida: Polychaeta) from southern and southeastern brazil, including a new species of Glycera. Biota Neotrop. 2007, 7, 41-59. [CrossRef]

133. Imajima, M. Deep-sea benthic polychaetes off Pacific coast of the northern Honshu, Japan. Natl. Mus. Nat. Sci. Monogr. 2009, 39, 192.

134. Böggemann, M.; Bienhold, C.; Gaudron, S.M. A new species of Glyceridae (Annelida:"Polychaeta") recovered from organic substrate experiments at cold seeps in the eastern Mediterranean Sea. Mar. Biodivers. 2012, 42, 47-54. [CrossRef]

135. Magalhaes, W.F.; Rizzo, A.E. Glyceridae (Annelida: Polychaeta) from Guam, Mariana Islands with description of a new species of Glycera Savigny in Lamarck, 1818. Zootaxa 2012, 3338, 60-68. [CrossRef]

136. Hossain, M.B.; Hutchings, P.A. Glycera sheikhmujibi n. sp.(Annelida: Polychaeta: Glyceridae): A new species of Glyceridae from the saltmarsh of Bangladesh. Diversity 2020, 12, 213. [CrossRef]

137. Arwidsson, I. Studien über die Familien Glyceridae und Goniadidae. Bergen. Mus. Årb. 1899, 2, 1-69.

138. Fauchald, K. Benthic polychaetous annelids from deep water off western Mexico and adjacent areas in the Eastern Pacific Ocean. Allan Hancock Monogr. Mar. Biol. 1972, 7, 1-575.

139. Müller, F. Einiges über die Annelidenfauna der Insel Santa Catharina an der brasilianischen Küste. Arch. Für Nat. 1858, 24, 211-220.

140. Audouin, J.V.; Milne Edwards, H. Classification des Annélides, et description de celles qui habitent les côtes de la France. Ann. Sci. Nat. Paris 1833, 30, 411-425. [CrossRef]

141. Hartman, O. Goniadidae, Glyceridae and Nephtyidae. Allan Hancock Pac. Exped. 1950, 15, 1-181.

142. Hartmann-Schröder, G. Polychaeten aus dem Roten Meer. Kiel. Meeresforsch. 1960, 16, 69-125.

143. Fauvel, P. Annélides polychètes nouvelles de l'Inde. I. Bull. Mus. D'hist. Nat. Paris 1928, 34, 90-96.

144. Hartman, O. Deep-water benthic polychaetous annelids off New England to Bermuda and other North Atlantic areas. Occas. Pap. Allan Hancock Found. 1965, 28, 1-378.

145. Böggemann, M. Polychaeten der Deutschen Küstengewässer (Auswertung einer “Senckenberg"-Fahrt im Sommer 1990). Ph.D. Thesis, Westfälischen Wilhelms-Universität Münster, Münster, Germany, 1995; pp. 1-281.

146. Böggemann, M.; Fiege, D. Proboscidial papillae of the Glyceridae (Annelida, Polychaeta)—A useful taxonomic character. Verh. Dtsch. Zool. Ges. Kurzpublikationen 1996, 89, 4.

147. Smith, L.E.; Trabanino, S.; Baerwald, R.J. Scanning electron microscopical observations of the proboscideal papillae of Glycinde armigera (Annelida: Polychaeta). Invertebr. Biol. 1995, 14, 46-50. [CrossRef]

148. Fiege, D.; Böggemann, M. Scanning electron microscopy of the proboscidal papillae of some European Glyceridae. Bull. Mar. Sci. 1997, 60, 559-563.

149. Wolf, G. Kieferorgane von Glyceriden (Polychaeta) ihre Funktion und ihr taxonomischer Wert. Senckenbergiana Marit. 1977, 9 , 261-283.

150. Ockelmann, K.W.; Vahl, O. On the biology of the polychaete Glycera alba, especially its burrowing and feeding. Ophelia 1970, 8 , 275-294. [CrossRef]

151. Fauchald, K.; Jumars, P.A. The diet of worms: A study of polychaete feeding guilds. Oceanogr. Mar. Biol. Annu. Rev. 1979, 17, 193-284.

152. Klawe, W.L.; Dickie, L.M. Biology of the bloodworm, Glycera dibranchiata Ehlers, and its relation to the bloodworm of the Maritime Provinces. Bull. Fish. Res. Board Can. 1957, 115, 1-37. 
153. Mattson, S. Burrowing and feeding of Goniada maculata Ørsted (Polychaeta). Sarsia 1981, 66, 49-51. [CrossRef]

154. Brown, B. Maine's baitworm fisheries: Resources at risk? Am. Zool. 1993, 33, 568-577. [CrossRef]

155. McIntosh, W.C. A monograph of the British annelids. Polychaeta. Syllidae to Ariciidae. Ray Soc. Lond. 1910, 2, 233-524. [CrossRef]

156. McIntosh, W.C. Notes from the Gatty Marine Laboratory, St. Andrews. No. 26. 1. On the Pacific, Atlantic and Japanese Palolo. 2. On the British Goniadidae and Ariciidae. 3. On the same groups found in the 'Porcupine' Expeditions of 1869 and 1870. 4. On the same groups dredged by Dr. Whiteaves of Canadain 1872 and 1873. 5. On the same groups procured by Canon Norman inNorway and Finmark. 6. On some Japanese Glyceridae. 7. On the form described as Hemipodus magellanicus in the Challenger. Ann. Mag. Nat. Hist. 1905, 715, 33-57.

157. Ben-Eliahu, M.N.; Golani, D. Polychaetes (Annelida) in the gut contents of goatfishes (Muliidae), with new polychaete records for the Mediterranean coast of Israel and the Gulf of Elat (Red Sea). Mar. Ecol. 1990, 11, 193-205. [CrossRef]

158. Ben-Eliahu, M.N.; Golani, D.; Ben-Tuvia, A. On predation of polychaetes (Annelides) by the squirrel- fish Adioryx ruber (Holocentridae), with a new polychaete record for the Mediterranean coast of Israel. Téthys 1983, 11, 15-19.

159. Benham, W.B. Notes on Polychaeta: Two new species of the genus Goniada. Bull. Soc. Linn. Normandie 1932, 9, 553-566.

160. Creaser, E.P., Jr. Reproduction of the bloodworm Glycera dibranchiata in the Sheepscot Estuary, Maine. J. Fish. Res. Board Can. 1973, 30, 161-166. [CrossRef]

161. Pettibone, M.H. Marine polychaete worms of the New England region. Part 1. Families Aphroditidae through Trochochaetidae. Bull. United States Natl. Mus. 1963, 227, 1-356.

162. Treadwell, A.L. Polychaetous annelids collected by Captain Robert A. Bartlett in Greenland, Fox Basin, and Labrador. J. Wash. Acad. Sci. 1937, 27, 23-36.

163. Brown, B. The worms crawl in, the worms crawl out, what's the bait worm fishery all about. Am. Zool. 1992, 32, 174A.

164. Creaser, E.P.; Clifford, D.A.; Hogan, M.J.; Sampson, D.B. A commercial sampling program for sandworms, Nereis virens Sars, and bloodworms, Glycera dibranchiata Ehlers, harvested along the Maine coast. Noaa Tech. Rep. 1983, NMFS SSRF-767, 1-56.

165. Dow, R.L. Chances in abundance of the marine worm, Glycera dibranchiata, associated with seawater temperature fluctuations. Commer. Fish. Rev. 1964, 7-9.

166. Dow, R.L. Fluctuations in marine species abundance during climatic cycles. Mar. Tech. Soc. J. 1973, 7, 38-42.

167. Olive, P.J.W. Polychaeta as a world resource: A review of exploitation as a sea angling baits, and the potential for aquaculture based production. Mém. Mus. Natl. D’hist. Nat. Paris 1994, 162, 603-610.

168. Taylor, P.M.; Saloman, C.H. Some effects of dredging and coastal development in Boca Ciega Bay, Florida. United States Fish Wild Life Serv. Fish. Bull. 1968, 67, 213-241.

169. Watson, G.J.; Murray, J.M.; Schaefer, M.; Bonner, A. Bait worms: A valuable and important fishery with implications for fisheries and conservation management. Fish Fish. 2017, 18, 374-388. [CrossRef]

170. Wilson, W.H., Jr.; Ruff, R.E. Species profiles: Life histories and environmental requirements of coastal fishes and invertebrates (North Atlantic)—Sandworm and bloodworm. United States Fish Wildl. Serv. Biol. Rep. 1988, 82, 1-23.

171. Böggemann, M. Annelida, Polychaeta, Phyllodocida, Glyceridae, Glycera branchiopoda Moore, 1911. In Handbook of Deep-Sea Hydrothermal Vent Fauna. Denisia 18; Desbruyères, D., Segonzac, M., Bright, M., Eds.; IFREMER: Brest, France, $2006 ;$ p. 195.

172. Desbruyères, D. Annelida, Polychaeta, Phyllodocida, Glyceridae, Glycera tesselata Grube, 1863. In Handbook of Deep-Sea Hydrothermal Vent Fauna. Denisia 18; Desbruyères, D., Segonzac, M., Bright, M., Eds.; IFREMER: Brest, France, 2006; pp. 196-197.

173. Schüller, M. Evidence for a role of bathymetry and emergence in speciation in the genus Glycera (Glyceridae, Polychaeta) from the deep Eastern Weddell Sea. Polar Biol. 2011, 34, 549-564. [CrossRef]

174. Böggemann, M.; Dietz, A. Glyceriformia (Annelida) from the deep sea of the Atlantic sector of the Southern Ocean. Polar Biol. 2016, 39, 1505-1510. [CrossRef]

175. Brasier, M.J.; Harle, J.; Wiklund, H.; Jeffreys, R.M.; Linse, K.; Ruhl, H.A.; Glover, A.G. Distributional patterns of polychaetes across the West Antarctic based on DNA barcoding and particle tracking analyses. Front. Mar. Sci. 2017, 4, 356. [CrossRef]

176. Hutchings, P.A.; Kupriyanova, E. Cosmopolitan polychaetes-Fact or fiction? Personal and historical perspectives. Invertebr. Syst. 2018, 32, 1-9. [CrossRef]

177. Menzel, L.; George, K.H.; Arbizu, P.M. Submarine ridges do not prevent large-scale dispersal of abyssal fauna: A case study of Mesocletodes (Crustacea, Copepoda, Harpacticoida). Deep Sea Res. Part I Oceanogr. Res. Pap. 2011, 58, 839-864. [CrossRef]

178. Böggemann, M. Glyceriformia (Annelida) of the abyssal SW Atlantic and additional material from the SE Atlantic. Mar. Biodivers. 2016, 46, 227-241. [CrossRef]

179. Rouse, G.W. Bias? What bias? The evolution of downstream larval-feeding in animals. Zool. Scr. 2000, 29, 213-236. [CrossRef]

180. Stramma, L.; England, M. On the water masses and mean circulation of the South Atlantic Ocean. J. Geophys. Res. Ocean. 1999, 104, 20863-20883. [CrossRef]

181. Boeckel, B.; Baumann, K.-H.; Henrich, R.; Kinkel, H. Coccolith distribution patterns in South Atlantic and Southern Ocean surface sediments in relation to environmental gradients. Deep Sea Res. Part I Oceanogr. Res. Pap. 2006, 53, 1073-1099. [CrossRef]

182. Clarke, A. Chapter 8. The Polar Deep Sea. In Ecosystems of the Deep Oceans. Ecosystems of the World 28; Tyler, P.A., Ed.; Elsevier: Amsterdam, The Netherlands, 2003; pp. 239-260.

183. Martinez Arbizu, P.; Brix, S. Bringing light into deep-sea biodiversity. Zootaxa 1866, 5, 2008.

184. Martínez Arbizu, P.; Schminke, H.K. DIVA-1 expedition to the deep sea of the Angola Basin in 2000 and DIVA-1 workshop in 2003. Org. Divers. Evol. 2005, 5, 11-12. [CrossRef] 
185. Ebbesmeyer, C.C.; Ingraham, W.J., Jr. Pacific toy spill fuels ocean current pathways research. Eostrans. Am. Geophys. Union 1994, 75, 425-430. [CrossRef]

186. Hohn, D. Moby-Duck. The True Story of 28,800 Bath Toys Lost at Sea and of the Beachcombers, Oceanographers, Environmentalists, and Fools, Including the Author, Who Went in Search of Them; Viking: New York, NY, USA, 2011.

187. Pettibone, M.H. Annelida. Polychaeta. In Synopsis and Classifiction of Living Organisms; Parker, S.P., Ed.; McGraw-Hill Book Company: New York, NY, USA, 1982; Volume 2, pp. 1-43.

188. Støp-Bowitz, C. Polychaeta from the Michael Sars North Atlantic deep-sea expedition 1910. Rep. Sci. Results Michael Sars North Atl. Deep-Sea Exped. 1948, 5, 1-91.

189. Uschakov, P.V. Fauna of the USSR. Polychaetes. Vol. I. Polychaetes of the suborder Phyllodociformia of the Polar Basin and the North-Western part of the Pacific. (Family Phyllodocidae, Alciopidae, Tomopteridae, Typhloscolecidae and Lacydoniidae). Akad. Nauk Sssr 1972, 102, 1-272. (In Russian)

190. Bergström, E. Zur Systematik der Polychætenfamilie der Phyllodociden. Zool. Bidr. Upps. 1914, 3, 37-224.

191. Dales, R.P. The evolution of the pelagic alciopid and phyllodocid polychaetes. Proc. Zool. Soc. Lond. 1955, 125, 411-420. [CrossRef]

192. Southern, R. Polychaeta of the coasts of Ireland. Pelagic Phyllodocidae. Fish. Irel. Sci. Investig. 1909, 3, 1-11.

193. Støp-Bowitz, C. A new genus and species (Yndolacia lopadorrhynchoides) of pelagic polychaetes representative of a new family, Yndolaciidae. Bull. Biol. Soc. Wash. 1987, 7, 128-130.

194. Rouse, G.W.; Pleijel, F. Problems in polychaete systematics. Hydrobiologia 2003, 496, 175-189. [CrossRef]

195. Rouse, G.W.; Pleijel, F. Reproductive Biology and Phylogeny of Annelida; Science Publishers Inc.: Enfield, NH, USA, 2006.

196. Southern, R. Polychaeta of the coasts of Ireland. 3. The Alciopidae, Tomopteridae and Typhloscolecidae. Fish. Irel. Sci. Investig. 1911, 3, 1-37.

197. Apstein, C. Vorbericht ueber Die Alciopiden und Tomopteriden der Plankton-Expedition 1; Lipsius \& Tischer: Kiel, Germany, 1899; pp. 135-138.

198. Apstein, C. Die Alciopiden und Tomopteriden der Plankton-Expedition 2; Lipsius: Kiel, Germany; Tischer: Leipzig, Germany, 1900; p. 62.

199. Dales, R.P. The pelagic Polychaetes of Monterey Bay, California. Ann. Mag. Nat. Hist. 1955, 12, 434-444. [CrossRef]

200. Dales, R.P. Pelagic polychaetes of the Pacific Ocean. Bull. Scripss Inst. Oceanogr. Univ. Calif. 1957, 7, 99-167.

201. Fauvel, P. Faune de France. Polychètes Errantes. Faune Fr. 1923, 5, 1-488.

202. Heath, H. A connecting link between the Annelida and the Echiuroidea Gephyrea armata. J. Morphol. 1930, 49, 223-249. [CrossRef]

203. Hartman, O. Polychaetous annelids collected by the USNS Eltanin and Staten Island cruises, chiefly from Antarctic Seas. Allan Hancock Monogr. Mar. Biol. 1967, 2, 1-387.

204. Osborn, K.J.; Rouse, G.W. Multiple origins of pelagicism within Flabelligeridae (Annelida). Mol. Phylogenet. Evol. 2008, 49, 386-392. [CrossRef] [PubMed]

205. Halanych, K.M.; Cox, L.N.; Struck, T.H. A brief review of holopelagic annelids. Integr. Comp. Biol. 2007, 47, 872-879. [CrossRef]

206. Struck, T.H.; Schult, N.; Kusen, T.; Hickman, E.; Bleidorn, C.; McHugh, D.; Halanych, K.M. Annelid phylogeny and the status of Sipuncula and Echiura. BMC Evol. Biol. 2007, 7, 57. [CrossRef]

207. Uljanin, B. Sur le Genre Sagitella N. Wagner. Arch. Zool. Exp. Gén. 1878, 7, 1-32.

208. Brigss, D.E.G.; Clarkson, E.N.K. The first tomopterid, a polychaete from the Carboniferous of Scotland. Lethaia 1987, $20,257-262$. [CrossRef]

209. Clark, N. Shrimping at Granton-the Muirhouse'shrimp-bed'revisited. Edinb. Geol. 2014, 55, 14-19.

210. Rice, S.A. Reproductive biology, systematics, and evolution in the polychaete family Alciopidae. Bull. Biol. Soc. Wash. 1987, 7, 114-127.

211. Støp-Bowitz, C. Some new or rare species of pelagic polychaetes from the Gulf of Guinea. Ophelia 1991, (Suppl. 5), 261-270.

212. Støp-Bowitz, C. Polychètes pélagiques des campagnes de l'Ombango dans les eaux équatoriales et tropicales Ouest-Africanes. Ed. L'orstrom Collect. Études Thèses 1992, 1992, 1-115.

213. Dales, R.P. An annotated list of the pelagic Polychaeta. Ann. Mag. Nat. Hist. Ser. 12 1956, 9, 289-304. [CrossRef]

214. Dales, R.P.; Peter, G. A synopsis of the Pelagic Polychaeta. J. Nat. Hist. 1972, 6, 55-92. [CrossRef]

215. Costa, A. Illustrazione Iconografica degli Anellidi rari o poco conosciuti del Golfo di Napoli. Annu. Dell'instituto Mus. Zool. Dell'univ. Napoli 1864, 2, 159-168.

216. Viguier, C. Etudes sur les Animaux inferieurs de la Baie d'Alger. Recherches sur les Annelides pelagiques. Arch. Zool. Exp. Gén. 1886, 4, 347-442.

217. Viguier, C. Nouvelles etudes sur le plankton de la baie d'Alger. Ann. Sci. Nat. Paris 1911, 13, 187-267.

218. Kolbasova, G.; Kosobokova, K.; Neretina, T. Bathy-and mesopelagic annelida from the Arctic Ocean: Description of new, redescription of known and notes on some "cosmopolitan" species. Deep Sea Res. Part I Oceanogr. Res. Pap. 2020, $165,103327$. [CrossRef]

219. Núñez, J.; Hernández, F.; Ocaña, O.; Jiménez, S. Poliquetos pélagicos de Canarias: Familias Iospilidae y Lopadorrhynchidae. Vieraea 1992, 21, 101-108.

220. Grube, A.E. Beschreibungen neuer oder wenig bekannter Anneliden. Arch. Nat. Berl. 1855, 21, 81-136.

221. Treadwell, A.L. Scientific Results of Cruise VII of the Carnegie during 1928-1929 under Command of Captain J.P. Ault. BiologyIV. Biological results of the last cruise of the Carnegie. III. Polychaetous annelids. Carnegie Inst. Wash. Publ. 1943, 55, 30-59. 
222. Eschscholtz, F. Berich ueber zoologische Ausbeute waehrend der Reise von Kronstadt bis St. Peter und Paul. Isis Von Oken 1825, $16,733-747$.

223. Quoy, J.R.; Gaimard, P. Observations zoologiques faites a bord de l'Astrolabe en mai 1826, dans le detroit de Gibraltar. Ann. Sci. Nat. Paris 1827, 10, 5-239.

224. Rosa, D. Nouve specie di Tomopteridi. Diagnosi preliminari. Boll. Mus. Zool. Anat. Comp. Torino 1908, $23,1$.

225. Day, J.H. A monograph on the Polychaetes of Southern Africa. Part 1. Errantia. Trustees Br. Mus. (Nat. Hist.) 1967, 656, 1-656. [CrossRef]

226. Fernández-Alamo, M.A. Tomopterids (Annelida: Polychaeta) from the Eastern Tropical Pacific Ocean. In: Proceedings of the VI International Polychaete Conference. Bull. Mar. Sci. 2000, 67, 45-53.

227. Wagner, N. Nouveau groupe d'Annelides. Tr. Obsch. Estest St. Petersburg 1872, 3, 344-347.

228. Levinsen, G.M.R. Spolia atlantica. Om nogle pelagiske Annulata. Skr. Fra Vidensk. I Kjoebenhavnmath.-Nat. Rekke 1885, 3, 321-344.

229. Krohn, A. Zoologische und anatomische Bemerkungen über die Alciopen. Arch. Nat. Berl. 1845, 11, 171-184.

230. Fauchald, K.; Rouse, G.W. Polychaete systematics: Past and present. Zool. Scr. 1997, 26, 71-138. [CrossRef]

231. Fernández-Álamo, M.A. Los poliquetos pelágicos (Annelida-Polychaeta) del Pacífico Tropical Oriental: Sistemática y Zoogeografía. Ph.D. Thesis, Universidad Nacional Autónoma de Mexico, Ciudad de México, Mexico, 1983.

232. Orensanz, J.M.; Ramirez, F.C. Taxonomía y distribución de los poliquetos pelágicos del Atlántico Sudoccidental. Bol. Inst. Biol. Mar. Mar Plata 1973, 21, 1-122.

233. Costello, M.J.; Bouchet, P.; Boxshall, G.; Arvanitidis, C.; Appeltans, W. European Register of Marine Species. Alciopini Ehlers. 1864. Available online: http:/ / www.marbef.org/data/aphia.php? $\mathrm{p}=$ taxdetails\&id=932 (accessed on 8 December 2020).

234. Chamberlin, R.V. The annelida polychaeta (In: Reps. Sci. Res. Expeds. U. S. Fish. Steamer "Albatross", 1891, 1899-1900 and 1904-1905). Mem. Mus. Comp. Zool. Harv. Coll. 1919, 48, 1-514.

235. Uschakov, P.V. Polychaeta of the Far Eastern seas of the Soviet Union. Akad. Nauk Sssr 1955, 56, 1-445. (In Russian)

236. Pleijel, F.; Dales, R.P. Polychaetes: British Phyllodocoideans, Typhloscolecoideans and Tomopteroideans; Universal Book Services/Dr. W. Backhuys: Avon, OH, USA, 1991; p. 202.

237. Hering, E. Zur Kenntnis der Alciopiden von Messina. Sber. Akad. Wiss. Wien 1892, 101, 713-768.

238. Wu, B.L.; Hua, L. Phylogeny of Alciopidae (pelagic polychaetes): A cladistic analysis. Mém. Mus. Natl. D’hist. Nat. Paris 1994, $162,317-322$.

239. Jiménez-Cueto, S.; Suárez-Morales, E. An account of Alciopina, Torrea, and Rhynconereella (Polychaeta: Alciopidae) of the western Caribbean Sea. Belg. J. Zool. 2008, 138, 70.

240. San Martín, G.; Álvarez-Campos, P.; Kondo, Y.; Núñez, J.; Fernández-Álamo, M.A.; Pleijel, F.; Goetz, F.E.; Nygren, A.; Osborn, K.J. New symbiotic association in marine annelids: Ectoparasites of comb jellies. Zool. J. Linn. Soc. 2020, 191, 672-694. [CrossRef]

241. Støp-Bowitz, C. Polychaeta. In Atlas del zooplancton del Atlántico Sudoccidental y Métodos de Trabajo con el Zooplancton Marino; Boltovskoy, D., Ed.; Instituto Nacional de Investigacion y Desarrollo Pesquero: Mar del Plato, Argentina, 1981; pp. 471-492.

242. Maurer, D.; Reish, D.J. Pelagic polychaetes from ice stations (Arlis I and II) in the Arctic Basin. J. Nat. Hist. 1984, 18, 381-387. [CrossRef]

243. Granata, L. Annelidi, Alciopidi e Fillidocidi. Raccolte planctoniche fatte dalla R. Nave Liguria nel viaggio di circonnavigazione del 1903-05 sotto il commando di S.A.R. Luigi di Savioa, Duca degli Abruzzi. Pub. R. Inst. Stud. Sup. Prat. Perfez. Firenze Sez. Sci. Fis. Nat. 1911, 2, 245-327.

244. Reibisch, J.G.F. Die Pelagischen Phyllodociden und Typhloscoleciden der Plankton-Expedition; Lipsius \& Tischer: Kiel, Germany, 1895.

245. Tebble, N. The distribution of pelagic polychaetes in the South Atlantic Ocean. Dis. Rep. 1960, 30, 161-299. [CrossRef]

246. Tebble, N. The distribution of pelagic polychaetes across the North Pacific Ocean. Bull. Br. Mus. (Nat. Hist.) 1962, 7, 371-492.

247. Dales, R.P. Pelagic polychaetes from the Bay of Biscay. Ann. Mag. Nat. Hist. 1957, 9, 661-664. [CrossRef]

248. Hartman, O. Catalogue of the polychaetous Annelids of the World, parts 1-2. Allan Hancock Found. Publ. Occas. Pap. 1959, 23, $1-628$.

249. Eklöf, J.; Pleijel, F.; Sundberg, P. Phylogeny of benthic Phyllodocidae (Polychaeta) based on morphological and molecular data. Mol. Phylogenet. Evol. 2007, 45, 261-271. [CrossRef]

250. Fernández-Álamo, M.A. Iospilidae Bergström, 1914. In Poliquetos (Annelida: Polychaeta) de México y América Tropical; LeónGonzález, J.A.B.-Z., Bastida Zavala, J.R., Carrera-Parra, L.F., García-Garza, M.E., Peña-Rivera, A., Salazar-Vallejo, S.I., Solís-Weiss, V., Eds.; Universidad Autónoma de Nuevo León: Monterrey, Mexico, 2009; pp. 245-250.

251. Tovar-Faro, B.; Leocádio, M.; de Paiva, P.C. Distribution of Iospilidae (Annelida) along the eastern Brazilian coast (from Bahia to Rio de Janeiro). Lat. Am. J. Aquat. Res. 2013, 41, 323-334.

252. Benham, W.B. The pelagic Polychaeta. Br. Antarct. Terra Nova Exped. Nat. Hist. Rep. Zool. 1929, 7, $183-201$.

253. Berkeley, C. A checklist of Polychaeta recorded from British Columbia since 1923, with references to name changes, descriptions, and synonymies. I. Errantia. Can. J. Zool. 1967, 45, 1049-1059. [CrossRef] [PubMed]

254. Berkeley, E.; Berkeley, C. Some further records of pelagic Polychaeta from the northeast Pacific north of latitude $40^{\circ} \mathrm{N}$ and east of longitude $175^{\circ} \mathrm{W}$, together with records of Siphonophora, Mollusca and Tunicata from the same region. Can. J. Zool. 1960, 38, 787-799. [CrossRef]

255. Savigny, J.-C. Système des annelides, principalement de celles des côtes de l'Égypte et de la Syrie, offrant les caractères tant distinctifs que naturels des Ordres, Familles et Genres, avec la description des espèces. Des 1822, 1, 1-128. [CrossRef] 
256. Yingst, D.R. The vertical distribution and reproductive biology of Pelagobia longicirrata (Annelida) in the central Arctic Ocean. Biol. Bull. 1974, 147, 457-465. [CrossRef] [PubMed]

257. Fernández-Álamo, M.A. Lopadorrhynchidae Claparède, 1868. In Poliquetos (Annelida: Polychaeta) de México y América Tropical; León-González, J.A.B.-Z., Bastida Zavala, J.R., Carrera-Parra, L.F., García-Garza, M.E., Peña-Rivera, A., Salazar-Vallejo, S.I., Solís-Weiss, V., Eds.; Universidad Autónoma de Nuevo León: Monterrey, Mexico, 2009; pp. 255-261.

258. Guglielmo, R.; Gambi, M.C.; Granata, A.; Guglielmo, L.; Minutoli, R. Composition, abundance and distribution of holoplanktonic polychaetes within the Strait of Magellan (southern America) in austral summer. Polar Biol. 2014, 37, 999-1015. [CrossRef]

259. Lana, P.C.; Blankensteyn, A. Poliquetas pelágicos coletados pelo N. Ap. Oc. "Barão de Teffé", durante a I Expedição Antártica Brasileira. Ann. Acad. Ciênc. 1986, 58, 13-22.

260. Lana, P.C.; Blankensteyn, A. Distribution patterns of pelagic polychaetes in the Southern Drake Passage and Bransfield Strait (January-February 1984). Nerítica 1987, 2, 37-64.

261. Sicinski, J. Pelagic Polychaeta in the Scotia Front west of Elephant Island (BIOMASS III, October-November 1986). Pol. Polar Res. 1988, 9, 277-282.

262. Bellan, G. Polychaeta. In European Register of Marine Species: A Check-List of the Marine Species in Europe and a Bibliography of Guides to Their Identification; Costello, M.J., Emblow, C., White, R.J., Eds.; Muséum National d'Histoire Naturelle: Paris, France, 2001; pp. 214-231.

263. Wilson, R.S. Family Pontodoridae. In Polychaetes \& Allies: The Southern Synthesis. Fauna of Australia. Vol. 4A. Polychaeta, Myzostomida, Pogonophora, Echiura, Sipuncula; Beesley, P.L.G., Ross, J.B., Glasby, C.J., Eds.; CSIRO Publishing: Melbourne, Australia, 2000; pp. 156-157.

264. Berkeley, E.; Berkeley, C. Notes on some pelagic and some swarming polychaeta taken off the coast of Perú. Can. J. Zool. 1964, 42, 121-133. [CrossRef]

265. Fernández-Álamo, M.A. Pontodoridae Bergström, 1914. In Poliquetos (Annelida: Polychaeta) de México y América Tropical; LeónGonzález, J.A.B.-Z., Bastida Zavala, J.R., Carrera-Parra, L.F., García-Garza, M.E., Peña-Rivera, A., Salazar-Vallejo, S.I., Solís-Weiss, V., Eds.; Universidad Autónoma de Nuevo León: Monterrey, Mexico, 2009; pp. 473-476.

266. Day, J.H. Zooplancton de la région de Nosy-Bé. X. The Biology of planktonic Polychaeta near Nosy-Bé, Madagascar. Cah. Orstom (Off. Rech. Sci. Tech. Outre-Mer) Ser. Océanogr. 1975, 13, 197-216.

267. Malaquin, A.; Carin, F. Note preliminaire sur les annelides pelagiques provenant des Campganes de l'Hirondelle et de la Princesse-Alice. Bull. L'inst. Océanogr. 1911, 205, 1-16.

268. Malaquin, A.; Carin, F. Tomopterides provenant des campagnes de l'Hirondelle et de la Princesse-Alice (1888-1910). Result. Camp. Sci. Monaco 1922, 61, 1-52.

269. Mileikovsky, S.A. On the systematic interrelationships within the Polychaeta and Annelida. An attempt to create an integrated system based on their larval morphology. In Essays on Polychaetous Annelids in Memory of Dr. Olga Hartman; Reish, D.J., Fauchald, K., Eds.; The Allan Hancock Foundation, University of Southern California: Los Angeles, CA, USA, 1977; pp. 503-524.

270. Fernández-Álamo, M.A. Tomopteridae Grube, 1850. In Poliquetos (Annelida: Polychaeta) de México y América Tropical; LeónGonzález, J.A.B.-Z., Bastida Zavala, J.R., Carrera-Parra, L.F., García-Garza, M.E., Peña-Rivera, A., Salazar-Vallejo, S.I., Solís-Weiss, V., Eds.; Universidad Autónoma de Nuevo León: Monterrey, Mexico, 2009; pp. 657-663.

271. Rakusa-Suszczewski, S. Predation of chaetognatha by Tomopteris helgolandica Greff. Ices J. Mar. Sci. 1968, 32, 226-231. [CrossRef]

272. Fernández-Álamo, M.A.; Thuese, A.B. Polychaeta. In South Atlantic Zooplankton; Boltovskoy, D., Ed.; Backhuys Publishers: Leiden, The Netherlands, 1999.

273. Fernández-Álamo, M.A. Composition, abundance and distribution of holoplanktonic polychaetes from the expedition "El Golfo 6311-12" of Scripps Institution of Oceanography. Sci. Mar. 2006, 70, 209-215. [CrossRef]

274. Ekman, S. Zoogeography of the Sea; Sidgwick \& Jackson, Ltd.: London, UK, 1953; p. 417.

275. Izuka, A. On the pelagic annelids of Japan. J. Coll. Sci. Imp. Univ. Tokyo 1914, 36, 1-14.

276. Fernández-Álamo, M.A. Composición, densidad y distribución de los poliquetos planctónicos (Phyllodocida: Tomopteridae) en el Domo Térmico de Costa Rica, Pacífico Tropical Oriental. Rev. Biol. Trop. 2020, 68, S238-S247. [CrossRef]

277. Guglielmo, R.; Bergamasco, A.; Minutoli, R.; Patti, F.P.; Belmonte, G.; Spanò, N.; Zagami, G.; Bonanzinga, V.; Guglielmo, L.; Granata, A. The Otranto Channel (South Adriatic Sea), a hot-spot area of plankton biodiversity: Pelagic polychaetes. Sci. Rep. 2019, 9, 19490. [CrossRef] [PubMed]

278. Chun, C. Die pelagische Thierwelt in groesseren Meerestiefen. Bibl. Zool. Cassel 1887, 1, 1-66.

279. Wilson, R.S. Family Tomopteridae. In Polychaetes \& Allies: The Southern Synthesis. Fauna of Australia. Vol. 4A. Polychaeta, Myzostomida, Pogonophora, Echiura, Sipuncula; Beesley, P.L.G., Ross, J.B., Glasby, C.J., Eds.; CSIRO Publishing: Melbourne, Australia, 2000; pp. 167-168.

280. Glasby, C.J.; Hutchings, P.A.; Fauchald, K.; Paxton, H.; Rouse, G.W.; Watson Russell, C.; Wilson, R.S. Class Polychaeta. In Polychaetes E Allies: The Southern Synthesis. Fauna of Australia. Vol. 4A. Polychaeta, Myzostomida, Pogonophora, Echiura, Sipuncula; Beesley, P.L.G., Ross, J.B., Glasby, C.J., Eds.; CSIRO Publishing: Melbourne, Australia, 2000; pp. 1-296.

281. Struck, T.H.; Halanych, K.M. Origins of holopelagic Typhloscolecidae and Lopadorhynchidae within Phyllodocidae (Phyllodocida, Annelida). Zool. Scr. 2010, 39, 269-275. [CrossRef]

282. Nygren, A.; Pleijel, F. Chimaeras and the origins of the holopelagic annelids Typhloscolecidae and Lopadorhynchidae: A reply to Struck \& Halanych (2010). Zool. Scr. 2011, 40, 112-114. [CrossRef] 
283. Feigenbaum, D. Predation on chaetoganths by typhloscolecid polychaetes, one explanation for headless specimens. J. Mar. Biol. Assoc. United Kingd. 1979, 59, 631-633. [CrossRef]

284. Øresland, V.; Pleijel, F. An ectoparasitic typhloscolecid polychaete on the chaetognath Eukronia hamata from the Antarctic Peninsula. Mar. Biol. 1991, 108, 429-432. [CrossRef]

285. Øresland, V.; Bray, R.A. Parasites and headless chaetognaths in the Indian Ocean. Mar. Biol. 2005, 147, 725-734. [CrossRef]

286. Fernández-Álamo, M.A. Typhloscolecidae Uljanin, 1878. In Poliquetos (Annelida: Polychaeta) de México y América Tropical; LeónGonzález, J.A.B.-Z., Bastida Zavala, J.R., Carrera-Parra, L.F., García-Garza, M.E., Peña-Rivera, A., Salazar-Vallejo, S.I., Solís-Weiss, V., Eds.; Universidad Autónoma de Nuevo León: Monterrey, Mexico, 2009; pp. 671-675.

287. Chambers, S.J. Polychaetes: British Chrysopetaloidea, Pisionoidea, and Aphroditoidea. Synop. Br. Fauna 1997, $54,1-202$.

288. Buzhinskaja, G. Two new genera of the pelagic family Yndolaciidae (Polychaeta) from the Arctic Ocean with an addition to the description of Yndolacia lopadorrhynchoides Stöp-Bowitz. Sarsia 2004, 89, 338-345. [CrossRef]

289. Fernández-Álamo, M.A.; Tejera, E.; León, M.E. Poliquetos pelágicos de las Islas de Cabo Verde: Resultados de la campaña TFMCBM/98, Proyecto Macaronesia 2000. Rev. Acad. Canar. Cienc. Folia Canar. Acad. Sci. 2003, 15, 87-98.

290. Zhadan, A.E.; Tzetlin, A.B. Polychaetes from deep pelagic zone of the Mid-Atlantic Ridge. Invertebr. Zool. 2008, 5, 97-109. [CrossRef]

291. Zrzavý, J.; Ríha, P.; Piálek, L.; Janouskovec, J. Phylogeny of Annelida (Lophotrochozoa): Total-evidence analysis of morphology and six genes. BMC Evol. Biol. 2009, 9, 189. [CrossRef] [PubMed]

292. Pleijel, F.; Dahlgren, T.G. Position and delineation of Chrysopetalidae and Hesionidae (Annelida, Polychaeta, Phyllodocida). Cladistics 1998, 14, 129-150. [CrossRef]

293. Levinsen, G.M.R. Systematisk geografisk Oversigt over do Nordiske Annulata, Gephyrea, Choetognathi, og Balanoglossi; II. Vidensk. Medd. Fra Dan. Nat. Foren. I Kjpbenhavn 1883, 4, 92-350.

294. Hatschek, B. System der Anneliden, ein vorläufiger Bericht. Lotos 1893, 13, 123-126.

295. Grube, A.E. Annulata Örstediana. Enumeratio Annulatorum, quae in itinere per Indiam occidentalem et Americam centralem annis 1845-1848 suscepto legit cl. A. S. Örsted, adjectis speciebus nonnullis a cl. H. Kröyero in itinere ad Americam meridionalem collectis. (Fortsaettelse). [Part 2]. Vidensk. Medd. Fra Dan. Nat. Foren. I Köbenhavn 1857, 1857, 158-186.

296. Kinberg, J.G.H. Annulata nova. Continuatio. [various errantia \& sedentaria]. Ofvers. Afk. Vetensk. Forh. Stockh. 1867, 22, 239-258.

297. Cuvier, G.L. Le Règne Animal Distribué D'après Son Organisation, pour Servir de Base à L'histoire Naturelle des Animaux et D'introduction à L'anatomie Comparée. Vol. 4 Les Zoophytes, les Tables, et les Planches; Deterville: Paris, France, 1817.

298. Fauchald, K. Nephtyidae (Polychaeta) from the Bay of Nha Trang, South Vietnam. Sci. Res. Mar. Invert. S. China Sea G. Thailand, 1959-61. NAGA Rep. 1968, 4, 5-33.

299. Friedrich, H. Polychaetenstudien. IV- Zur polychaetenfauna der Barents-See. Kiel. Meeresforsch. 1939, 3, $122-132$.

300. Grube, A.E. Anneliden-Ausbeute S.M.S. Gazelle. Mon. K. Preuss. Akad. Wiss. Zu Berl. 1877, 509-554.

301. Ehlers, E. Report on the annelids of the dredging expedition of the U.S. coast survey steamer Blake. Mem. Mus. Comp. Zool. Harv. Coll. 1887, 15, 1-335.

302. Fauvel, P. Annélides polychètes non-pélagiques provenant des campagnes de l'Hirondelle et de la Princesse-Alice (1885-1910). Résultats Des. Camp. Sci. Accompl. Sur Son Yatch Par Albert Ier Prince Souver. Monaco 1914, 46, 1-432.

303. Benham, W.B. Report on the Polychaeta obtained by the F.I.S. 'Endeavour' on the coasts of New South Wales, Victoria, Tasmania and South Australia. Part 2. In Fisheries. Zoological (and Biological) results of the Fishing Experiments carried out by F.I.S. "Endeavour", 1909-1914; H.C. Dannevig: Sydney, Australia, 1916; Volume 4, pp. 127-169.

304. Hartman, O. Polychaetous annelids. Part II. Chrysopetalidae to Goniadidae. Allan Hancock Pac. Exped. 1940, 7, $173-287$.

305. Petterson, H.; Jerlov, N.G.; Kullenberg, B. Reports of the Swedish Deep-Sea Expedition 1947-1948; Swedish National Scientific Research Council: Stockholm, Sweden, 1951.

306. Dnestrovskaya, N.Y.; Jirkov, I.A. Nephtyidae Grube, 1850. In Polikhety Severnogo Ledovitogo Okeana [Polychaeta of the Arctic Ocean]; Jirkov, I.A., Ed.; Yanus-K Press: Moscow, Russia, 2001; pp. 181-212.

307. Dnestrovskaya, N.Y.; Jirkov, I.A. Micronephthys (Polychaeta: Nephtyidae) of Northern Europe and Arctic. Invertebr. Zool. 2010, 7, 107-121. [CrossRef]

308. Dnestrovskaya, N.Y.; Jirkov, I.A. Identification key for Nephtyidae (Polychaeta) of the eastern Atlantic and the North Polar Basin. Invertebr. Zool. 2012, 9, 143-150. [CrossRef]

309. Fauchald, K. Nephtyidae (Polychaeta) from Norwegian waters. Sarsia 1963, 13, 1-32. [CrossRef]

310. Foret-Montardo, P. Étude systématique et écologique des Nephtyidae (Polychètes Errantes) des parages de Marseille. Téthys 1969, $1,807-832$.

311. Jirkov, I.A.; Paraketsova, N. Review of the species of the genus Micronephthys (Polychaeta: Nephthyidae) from the white sea. Zool. Zhurnal 1996, 75, 831-840. (In Russian)

312. Laborda, A.J. Annelida, Polychaeta I. In Fauna Iberica, 25th ed.; Viéitez, J.M., Alós, C., Parapar, J., Besteiro, C., Moreira, J., Nuñez, J., Laborda, A.J., San Martin, G., Eds.; Museo Nacional de Ciencias Naturales (MNCN-CSIC): Madrid, Spain, 2004; pp. 390-419.

313. Rainer, S.F. Nephtys pente sp. nov. (Polychaeta: Nephtyidae) and a Key to Nephtys from Northern Europe. J. Mar. Biol. Assoc. UK 1984, 64, 899-907. [CrossRef]

314. Rainer, S.F. Redescription of Nephtys assimilis and N. kersivalensis (Polychaeta: Phyllodocida) and a key to Nephtys from Northern Europe. J. Mar. Biol. Assoc. UK 1989, 69, 875-889. [CrossRef] 
315. Rainer, S.F. The genus Nephtys (Polychaeta: Phyllodocida) in Northern Europe: Redescription of N. hystricis and N. incisa. J. Nat. Hist. 1990, 24, 361-372. [CrossRef]

316. Rainer, S.F. The genus Nephtys (Polychaeta: Phyllodocida) of northern Europe: A review of species, including the description of N. pulchra sp. n. and a key to the Nephtydae. Helgoländer Meeresunters. 1991, 45, 65-96. [CrossRef]

317. Rainer, S.F. Nephtyid Polychaetes from the Faroe Islands. Northurlandahsth Arsrit 1992, 1991-1992, 80-81.

318. Ravara, A.; Cunha, M.R.; Pleijel, F. Nephtyidae (Annelida, Polychaeta) from southern Europe. Zootaxa 2010, 2682, 1-68. [CrossRef]

319. Hartman, O. Review of the annelid worms of the family Nephtyidae from the Northeast Pacific, with descriptions of five new species. Proc. United States Natl. Mus. 1938, 85, 143-158. [CrossRef]

320. Hartman, O. Polychaeta Errantia of the Antarctica. Antarct. Res. Ser. 1964, 3, 1-131.

321. Hartman, O. Polychaeta from the Weddel Sea quadrant, Antarctica. Antarct. Res. Ser. 1978, 26, 125-223.

322. Alalykina, I.L.; Dnestrovskaya, N.Y.; Jirkov, I.A. Identification key to Nephtyidae (Annelida) of the Sea of Okhotsk. ZooKeys 2017, 684, 1-18. [CrossRef]

323. Dixon-Bridges, K.; Gladstone, W.; Hutchings, P. One new species of Micronephthys Fredrich, 1939 and one new species of Nephtys Cuvier, 1817 (Polychaeta: Phylllodocidae: Nephtyidae) from eastern Australia with notes on Aglaophamus australiensis (Fauchald, 1965) and a key to all Australian species. Zootaxa 2014, 3872, 513-540. [CrossRef]

324. Dnestrovskaya, N.Y. Identification key to Nephtyidae (Annelida) of the Black Sea. ZooKeys 2020, 908, 1-17. [CrossRef]

325. Fauchald, K. Some Nephtyidae (Polychaeta) from Australian waters. Rec. Aust. Mus. 1965, 26, 333-340. [CrossRef]

326. Franco, N.B.; Rizzo, A.E. Nephtyidae (Annelida: Polychaeta) from the Campos Basin, including two new species and a new record. Zootaxa 2016, 4114, 291-308. [CrossRef] [PubMed]

327. Hartman, O.; Fauchald, K. Deep-water benthic polychaetous annelids off New England to Bermuda and other North Atlantic Areas. Part II. Allan Hancock Monogr. Mar. Biol. 1971, 6, 1-327.

328. Hilbig, B. The annelida. Part 1. Oligochaeta: Phyllodocida (Phyllodocidae to Paralacydoniidae). In Taxonomic Atlas of the Benthic Fauna of the Santa Maria Basin and the Western Santa Barbara Channel; Blake, J.A., Hilbig, B., Scott, P.H., Eds.; US Department of the Interior, Minerals Management Service, Pacific OCS Region: Santa Barbara, CA, USA, 1997; Volume 42, pp. 317-349.

329. Imajima, M.; Takeda, Y. Nephtyidae (Polychaeta) from Japan. I. The genera Inermonephtys, Micronephtys and Aglaophamus. Bull. Natl. Sci. Mus. Tokyo 1985, 11, 57-90.

330. Imajima, M.; Takeda, Y. Nephtyidae (Polychaeta) from Japan. II. The genera Dentinephtys and Nephtys. Bull. Natl. Sci. Mus. Tokyo 1987, 13, 41-77.

331. Jung, R.H.; Hong, J.S. Nephtyidae (Annelida: Polychaeta) from the Yellow Sea. Bull. Mar. Sci. 1997, 60, 371-384.

332. Lana, P.C. Nephtyidae (Annelida: Polychaeta) do litoral do estado do Paraná (Brasil). Nerítica 1986, 1, 135-154. [CrossRef]

333. Murray, A.; Wong, E.; Hutchings, P.A. Nephtyidae (Annelida: Phyllodocida) of Lizard Island, Great Barrier Reef, Australia. Zootaxa 2015, 4019, 414-436. [CrossRef]

334. Nateewathana, A.; Hylleberg, J. Nephtyid polychaetes from the west coast of Phuket Island, Andaman Sea, Thailand with description of five new species. Proc. Linn. Soc. New South. Wales 1986, 108, 195-215.

335. Paxton, H. Contribution to the study of Australian Nephtyidae (Polychaeta). Rec. Aust. Mus. 1974, 29, 197-208. [CrossRef]

336. Pérez-Torrijos, J.; Hernández-Alcántara, P.; Solís-Weiss, V. Nephtyidae (Polychaeta) from the Gulf of California (Mexican Pacific) with the description of two new species of Aglaophamus. J. Mar. Biol. Assoc. UK 2009, 89, 697-710. [CrossRef]

337. Rainer, S.F.; Hutchings, P. Nephtyidae (Polychaeta: Errantia) from Australia. Rec. Aust. Mus. 1977, 31, 307-347. [CrossRef]

338. Rainer, S.F.; Kaly, U.L. Nephtyidae (Polychaeta: Phyllodocida) of Australia: New species from the North West Shelf, and a key to Australian species. J. Nat. Hist. 1988, 22, 685-703. [CrossRef]

339. Rizzo, A.E.; Amaral, A.C.Z. Nephtyidae (Annelida: Polychaeta) from São Paulo state, Brazil, including a new record for the Brazilian coast. Biota Neotrop. 2007, 7, 253-263. [CrossRef]

340. Rozbaczylo, N.; Castilla, J.C. La familia Nephtyidae en Chile (Annelida, polychaeta). Stud. Neotrop. Fauna 1974, 9, 179-206. [CrossRef]

341. Taylor, J.L. Chapter 35. Family Nephtyidae Grube, 1850. In Taxonomic Guide to the Polychaetes of the Northern of Gulf of Mexico; Uebelacker, J.M., Johnson, P.G., Eds.; Barry A. Vittor \& Associates, Inc.: Mobile, AL, USA, 1984; pp. 1-20.

342. Pattaratumrong, M.S.; Wongkhamhaeng, K. The molecular Identification of Nephtys species (Polychaeta: Phyllodocida) from Songkhla Lake, Southern Thailand. Naresuan Univ. J. Sci. Technol. 2019, 27, 1-9. [CrossRef]

343. Ravara, A.; Wiklund, H.; Cunha, M.R.; Pleijel, F. Phylogenetic relationships within Nephtyidae (Polychaeta, Annelida). Zool. Scr. 2010, 39, 394-405. [CrossRef]

344. Clark, R.B. Observations on the food of Nephtys. Limnol. Oceanogr. 1962, 7, 380-385. [CrossRef]

345. Schubert, A.; Reise, K. Predatory effects of Nephtys hombergii on other polychaetes in tidal flat sediments. Mar. Ecol. Prog. Ser. 1986, 34, 117-124. [CrossRef]

346. Würzberg, L.; Peters, J.; Schüller, M.; Brandt, A. Diet insights of deep-sea polychaetes derived from fatty acid analyses. Deep Sea Res. Part. II Top. Stud. Oceanogr. 2011, 58, 153-162. [CrossRef]

347. Benham, W.B. Report on the Polychaeta obtained by the F.I.S. 'Endeavour' on the coasts of New South. Wales, Victoria, Tasmania and South. Australia, Part. 1; H.C. Dannevig: Sydney, Australia, 1915; pp. 171-237.

348. Eliason, A. Polychaeta. In Reports of the Swedish Deep-Sea Expedition 1947-1948; Petterson, H., Jerlov, N.G., Kullenberg, B., Eds.; Swedish National Scientific Research Council: Stockholm, Sweden, 1951; Volume 2. 
349. Demopoulos, A.W.J.; Bourque, J.R.; Durkin, A.; Cordes, E.E. The influence of seep habitats on sediment macrofaunal biodiversity and functional traits. Deep Sea Res. Part. I Oceanogr. Res. Pap. 2018, 142, 77-93. [CrossRef]

350. Grupe, B.M.; Krach, M.L.; Pasulka, A.L.; Maloney, J.M.; Levin, L.A.; Frieder, C.A. Methane seep ecosystem functions and services from a recently discovered southern California seep. Mar. Ecol. 2015, 36, 91-108. [CrossRef]

351. Levin, L.A.; Ziebis, W.; Mendoza, G.F.; Growney, V.A.; Tryon, M.D.; Brown, K.M.; Mahn, C.; Gieskes, J.M.; Rathaburn, A.E. Spatial heterogeneity of macrofauna at northern California methane seeps: Influence of sulfide concentration and fluid flow. Mar. Ecol. Prog. Ser. 2003, 265, 123-139. [CrossRef]

352. Serrano, A.; Velasco, F.; Olaso, I. Polychaete annelids in the diet of demersal fish from the southern shelf of the Bay of Biscay. $J$. Mar. Biol. Assoc. United Kingd. 2003, 83, 619-623. [CrossRef]

353. Varadharajan, D.; Soundarapandian, P. Contribution of polychaetes in feeding capability of commercially important crabs, South East coast of India. Mar. Sci. Res. Dev. 2013, 3, 2-6. [CrossRef]

354. Day, J.H. The Polychaete fauna of South Africa. Part 2. Errant species from Cape shores and estuaries. Ann. Natal Mus. 1953, 12, 397-441.

355. Meißner, K.; Darr, A.; Rachor, E. Development of habitat models for Nephtys species (Polychaeta: Nephtyidae) in the German Bight (North Sea). J. Sea Res. 2008, 60, 276-291. [CrossRef]

356. Olive, P.J.W.; Garwood, P.R.; Bentley, M.G. Reproductive failure and oosorption in Polychaeta in relation to their reproductive strategies. Bull. Soc. Zool. Fr. 1981, 106, 263-268.

357. Olive, P.J.W.; Morgan, P.J. The reproductive cycles of four British intertidal Nephtys species in relation to their geographical distribution (Polychaeta: Nephtyidae). In: Systematics, biology and morphology of world polychaeta. Proceedings of the Second International Polychaeta Conference. Ophelia 1991, 5, 351-361.

358. Rainer, S.F. Distribution, growth and production of Nephtys hombergii and N. assimilis (Polychaeta: Nephtyidae) in benthic communities of the North Sea. Bull. Mar. Sci. 1991, 48, 330-345.

359. Olive, P.J.W.; Garwood, P.R.; Bentley, M.G.; Wright, N.H. Reproductive success, relative abundance and population structure of two species of Nephtys in an estuarine beach. Mar. Biol. 1981, 63, 189-196. [CrossRef]

360. Desroy, N.; Retière, C. The influence of structure and dynamics of infaunal predator populations on predatory activity: The example of Nephtys hombergii. Estuar. Coast. Shelf Sci. 2003, 58, 445-453. [CrossRef]

361. Southern, R. Fauna of the Chilka Lake and also of fresh and brackish waters in other parts of India. Mem. Indian Mus. Calcutta 1921, 5, 563-659.

362. Monro, C.A.A. On some freshwater polychaetes from Uruguay. Ann. Mag. Nat. Hist. Mus. Lond. 1937, 10, 241-250. [CrossRef]

363. Wilson, R.S. Polychaetes \& Allies: The southern synthesis. Fauna of Australia. Vol. 4a Polychaeta, Myzostomida, Pogonophora, Echiura, Sipuncula. In Family Nephtyidae; Beesley, P.L., Ross, G.J.B., Glasby, C.J., Eds.; CSIRO Publishing: Melbourne, Australia, 2000; pp. 136-137.

364. Perejaslavzeva, S.M. Supplementations to the fauna of the Black Sea. Proc. Soc. Nat. Kharkov Univ. 1891, 25, $235-274$.

365. Wesenberg-Lund, E. Polychaetes of the Iranian Gulf. Dan. Sci. Investig. Iran. 1949, 4, 247-400.

366. Savigny, J.C. Troisième partie. Systèmes de diverses classes d'animaux sans vertèbres. Système des annélides, principalement de celles des côtes de l'Égypte et de la Syrie, offrant les charactères tant distinctifs que naturels des Ordres, Familles et Genres, avec la description des espèces. Descr. L'egyptehist. Nat. 1822, 3, 1-128.

367. Böggemann, M. Polychaeten aus der Deutschen Bucht. Taxonomische Beabeitung und Dokumentation der vom Forschungsinstitut Senckenberg hauptsachlich in der Deutschen Bucht gesammelten Polychaeten. C. Forschung. Senckenb. 1997, 202, 91-96.

368. Malm, A.W. Annulata i hafvet utmed Sveriges westkust och omkring Göteborg. Göteborgs K. Vetensk. Och Vitterh. Handl. 1874, 14, 67-105.

369. Gravier, C. Contribution à l'étude des Annélides Polychètes de la Mer Rouge. Familles des Nereidiens, Aphroditiens, tribus des Polynoina, Sigalionina, familles des Amphinomiens, Palmyriens. Nouv. Arch. Mus. Paris Sér. 4 1902, 3, 147-268.

370. Lamarck, J.B. Ordre Second. Radiaires Échinodermes. Hist. Nat. Des. Animaux Sans Vertèbres 1816, 2, $522-568$.

371. Marenzeller, E. Südjapanische Anneliden.III. Denkschr. Akad. Wiss. Wien. 1902, 72, 563-582.

372. Müller, J.X.; Troschel, F.H. System der Asteriden; F. Papier, Druck und Verlag von Friedrich Vieweg und Son: Brünswick, Germany, 1842.

373. Seidler, H.J. Beitrage zur kenntnis der Polynoiden, I. Arch. Nat. Berl. 1923, 89, 1-217.

374. Uschakov, P.V.; Reish, D.J.; Fauchald, K. Phylogenetic relationships in the family Polynoidae (Polychaeta). In Essays on Polychaetous Annelids in Memory of Dr. Olga Hartman; University of Southern California, Allan Hancock Press: Los Angeles, CA, USA, 1977; pp. 29-38.

375. Struck, T.H.; Purschke, G.; Halanych, K.M. A scaleless scale worm: Molecular evidence for the phylogenetic placement of Pisione remota (Pisionidae, Annelida). Mar. Biol. Res. 2005, 1, 243-253. [CrossRef]

376. Wiklund, H.; Nygren, A.; Pleijel, F.; Sundberg, P. Phylogeny of Aphroditiformia (Polychaeta) based on molecular and morphological data. Mol. Phylogenet. Evol. 2005, 37, 494-502. [CrossRef]

377. Norlinder, E.; Nygren, A.; Wiklund, H.; Pleijel, F. Phylogeny of scale-worms (Aphroditiformia, Annelida), assessed from 18SrRNA, 28SrRNA, 16SrRNA, mitochondrial cytochrome c oxidase subunit I (COI), and morphology. Mol. Phylogenet. Evol. 2012, 65, 490-500. [CrossRef] [PubMed] 
378. Zhang, Y.; Sun, J.; Rouse, G.W.; Wiklund, H.; Pleijel, F.; Watanabe, H.K.; Chen, C.; Qian, P.-Y.; Qiu, J.-W. Phylogeny, evolution and mitochondrial gene order rearrangement in scale worms (Aphroditiformia, Annelida). Mol. Phylogenet. Evol. 2018, 125, $200-231$. [CrossRef] [PubMed]

379. Bonifácio, P.; Menot, L. New genera and species from the Equatorial Pacific provide phylogenetic insights into deep-sea Polynoidae (Annelida). Zool. J. Linn. Soc. 2018, 185, 555-635. [CrossRef]

380. Pettibone, M.H. Revision of the genus Macellicephala McIntosh and the subfamily Macellicephalinae Hartmann-Schröder (Polychaeta: Polynoidae). Smithson. Contrib. Zool. 1976, 229, 1-71.

381. Uschakov, P.V. Polychaetes of the Suborder Aphroditiformia of the Arctic Ocean and the Northwestern Part of the Pacific, Families Aphroditidae and Polynoidae. Fauna Sssrmnogoshchetinkovyye Chervi 1982, 2, 1-272. (In Russian)

382. Tebble, N.; Chambers, S. Polychaetes from Scottish Waters, Part. 1. Family Polynoidae; Royal Scottish Museum: Edinburgh, UK, 1982; p. 73.

383. Britayev, T.A.; Fauchald, K. New species of symbiotic scaleworms Asterophilia (Polychaeta, Polynoidae) from Vietnam. Invertebr. Zool. 2005, 2, 15-22. [CrossRef]

384. Nobili, G. Diagnoses préliminaires de vingt-huit espèces nouvelles de stomatopodes et décapodes macroures de la Mer Rouge. Bull. Mus. D'hist. Nat. Paris 1904, 10, 228-238.

385. Gray, J.E. XXXII. A synopsis of the genera and species of the class Hypostoma (Asterias, Linnaeus). Ann. Mag. Nat. Hist. 1840, 6, 275-290. [CrossRef]

386. Leach, W.E. Annulosa. In Encyclopedia Britannica, Supplement to the Fourth, Fifth and Sixth Editions; Encyclopedia Britannica, Inc.: London, UK, 1816; Volume 1, pp. 401-453.

387. Malmgren, A.J. Nordiska Hafs-Annulater. [part one of three]. Öfvers. Königlich Vetensk. Förhandlingarstockholm 1865, $22,51-110$.

388. Nygren, A.; Norlinder, E.; Panova, M.; Pleijel, F. Colour polymorphism in the polychaete Harmothoe imbricata (Linnaeus, 1767). Mar. Biol. Res. 2011, 7, 54-62. [CrossRef]

389. Pettibone, M.H. A new scale-worm commensal with deep-sea mussels on the Galapagos hydrotermal vent (Polychaeta: Polynoidae). Proc. Biol. Soc. Wash. 1984, 97, 226-239.

390. Delle Chiaje, S. Descrizione et Notomia Degli Animali Invertebrati de la Sicilia Cateriore Oservati Vivi Negli Anni 1822-1830; Batelli \& Co.: Naples, Italy, 1841; Volume 5, pp. 1-137.

391. Pettibone, M.H.; Reish, D.J.; Fauchald, K. Review of Halosydnopsis and related genera (Polychaeta: Polynoidae: Lepidonotinae). In Essays on Polychaetous Annelids in Memory of Dr. Olga Hartman; The Allan Hancock Foundation, University of Southern California: Los Angeles, CA, USA, 1977; pp. 39-62.

392. Pettibone, M.H. Scaled polychaetes (Polynoidae) associated with ophiuroids and other invertebrates and review of species referred to Malmgrenia McIntosh and replaced by Malmgeniella Hartman, with descriptions of new taxa. Smithson. Contrib. Zool. 1993, 538, 1-92. [CrossRef]

393. Nemésio, A. A replacement name for Wilsoniella Pettibone, 1993 (Annelida: Polynoidae), junior homonym of Wilsoniella Khalfin, 1939 (Brachiopoda: Rhynchonellida), and revalidation of Pessoaiella Guimarães, 1940 over Wilsoniella Eichler, 1940 (Phthiraptera: Ischnocera: Philopteridae) also a junior homonym of Wilsoniella Khalfin, 1939. Zootaxa 2006, 1260, 67-68.

394. Serpetti, N.; Taylor, M.L.; Brennan, D.; Green, D.H.; Rogers, A.D.; Paterson, G.L.J.; Narayanaswamy, B.E. Ecological adaptations and commensal evolution of the Polynoidae (Polychaeta) in the Southwest Indian Ocean Ridge: A phylogenetic approach. Deep Sea Res. Part. II Top. Stud. Oceanogr. 2017, 137, 273-281. [CrossRef]

395. Shields, M.A.; Glover, A.G.; Wiklund, H. Polynoid polychaetes of the Mid-Atlantic Ridge and a new holothurian association. Mar. Biol. Res. 2013, 9, 547-553. [CrossRef]

396. Ditlevsen, H. Annelids. I; H. Hagerup: Copenhagen, Denmark, 1917; Volume VI, p. 71.

397. Hanley, J.R.; Burke, M. A new genus and species of commensal scaleworm (Polychaeta, Polynoidae) from Broome, Western Australia. Beagle Rec. Mus. Art Gall. North. Territ. 1989, 6, 97-103.

398. Pettibone, M.H. Review of some species referred to Scalisetosus McIntosh (Polychaeta, Polynoidae). Proc. Biol. Soc. Wash. 1969, 82, $1-30$.

399. Hartman, O. A review of the types of polychaetous annelids at the Peabody Museum of Natural History, Yale University. Bull. Bingham Oceanogr. Coll. 1942, 8, 1-98.

400. Michaelsen, W. Polychaeten von Ceylon. Jb. Hamb. Wiss. Anst. 1892, 9, 1-23.

401. Hutchings, P.A.; Murray, A. Taxonomy of Polychaetes from the Hawkesbury River and the Southern Estuaries of New South Wales, Australia. Rec. Aust. Mus. 1984, 36, 1-119. [CrossRef]

402. Gonzalez, B.C.; Martínez, A.; Borda, E.; Iliffe, T.M.; Fontaneto, D.; Worsaae, K. Genetic spatial structure of an anchialine cave annelid indicates connectivity within-But not between-Islands of the Great Bahama Bank. Mol. Phylogenet. Evol. 2017, 109, 259-270. [CrossRef] [PubMed]

403. Sarvala, J. Ecology of Harmothoe sarsi (Malmgren) (Polychaeta, Polynoidae) in the northern Baltic area. Ann. Zool. Fenn. 1971, 8 , 231-309.

404. Plyuscheva, M.; Martin, D.; Britayev, T.A. Diet analyses of the scale-worms Lepidonotus squamatus and Harmothoe imbricata (Polychaeta, Polynoidae) in the White Sea. Mar. Biol. Res. 2010, 6, 271-281. [CrossRef] 
405. Desbruyères, D.; Laubier, L. Exploitation d'une source de matière organique concentrée dans l'océan profond: Intervention d'une annélide polychète nouvelle [Exploitation of a concentrated organic matter source in the deep sea: Role of a new polychaetous annelid]. C. R. Hebdomaidaire Des. Séances L'acad. Des. Sci. 1988, 307, 329-336.

406. Hatch, A.S.; Liew, H.; Hourdez, S.; Rouse, G.W. Hungry scale worms: Phylogenetics of Peinaleopolynoe (Polynoidae, Annelida), with four new species. ZooKeys 2020, 932, 27-74. [CrossRef]

407. Coll, M.; Piroddi, C.; Steenbeek, J.; Kaschner, K.; Ben Rais Lasram, F.; Aguzzi, J.; Ballesteros, E.; Bianchi, C.N.; Corbera, J.; Dailianis, T.; et al. The biodiversity of the Mediterranean Sea: Estimates, patterns and treats. PLoS ONE 2010, 5, e11842. [CrossRef] [PubMed]

408. Kiseleva, M.I. Mnogoshchetinkovye Chervi (Polychaeta) Chernogo i Azovskogo Morei [Polychaeta from the Black and Azov Seas]; Russian Academy of Sciences, Kola Scientific Center, Murmansk Marine Biological Institute: Murmansk, Russian; National Academy of Sciences of Ukraine, A.O. Kovalevsky Institute of Biology of the South Seas, Apatity, KSCRAN Publications: Kiev, Ukraine, 2004.

409. Horst, R. On new and little-known species of Polynoinae from the Netherland's East Indies. Zool. Meded. Leiden 1915, 1, 2-20.

410. Potts, F.A. Polychaeta of the Indian ocean. Pt. 2. The Palmyridae, Aphroditidae, Polynoidae, Acoetidae and Sigalionidae. Trans. Linn. Soc. Zool. 1910, 16, 325-353. [CrossRef]

411. Barnich, R.; Fiege, D.; Sun, R. Polychaeta (Annelida) of Hainan Island, South China Sea Part III. Aphroditoidea. Species Divers. 2004, 9, 285-329. [CrossRef]

412. Britayev, T.A.; Antokhina, T.I. Chapter 1. Symbiotic polychaetes of from the Bay of Nhatrang Bay, Vietnam. In Benthic fauna of the Bay of Nhatrang, Southern Vietnam. Volume 2; Britayev, T.A., Pavlov, D.S., Eds.; KMK Scientific Press Ltd.: Moscow, Russia, 2012; Volume 2, pp. 11-54.

413. Salazar-Vallejo, S.I.; Carrera-Parra, L.F.; Muir, A.I.; León-González, J.A.d.; Piotrowsky, C.; Sato, M. Polychaete species (Annelida) described from the Philippine and China Seas. Zootaxa 2014, 3842, 1-68. [CrossRef]

414. Glasby, C.J.; Lee, Y.-L.; Hsueh, P.-W. Marine Annelida (excluding clitellates and siboglinids) from the South China Sea. Raffles Bull. Zool. 2016, (Suppl. 34), 178-234. Available online: https://www.researchgate.net/profile/Pan-Wen-Hsueh-2/publication/3062 16590_Marine_Annelida_excluding_clitellates_and_siboglinids_from_the_South_China_Sea/links /57f3505908ae280dd0b56b0 c/Marine-Annelida-excluding-clitellates-and-siboglinids-from-the-South-China-Sea.pdf (accessed on 4 February 2021).

415. Ravara, A.; Cunha, M.R. Two new species of scale worms (Polychaeta: Aphroditiformia) from deep-sea habitats in the Gulf of Cadiz (NE Atlantic). Zootaxa 2016, 4097, 422-450. [CrossRef] [PubMed]

416. Taboada, S.; Silva, A.S.; Neal, L.; Cristobo, J.; Ríos, P.; Álvarez-Campos, P.; Hestetun, J.T.; Koutsouveli, V.i.; Sherlock, E.; Riesgo, A. Insights into the symbiotic relationship between scale worms and carnivorous sponges (Cladorhizidae, Chondrocladia). Deep Sea Res. Part. I Oceanogr. Res. Pap. 2020, 156, 103191. [CrossRef]

417. Taboada, S.; Serra Silva, A.; Díez-Vives, C.; Neal, L.; Cristobo, J.; Ríos, P.; Hestetun, J.T.; Clark, B.; Rossi, M.E.; Junoy, J.; et al. Sleeping with the enemy: Unravelling the symbiotic relationships between the scale worm Neopolynoe chondrocladiae (Annelida: Polynoidae) and its carnivorous sponge hosts. Zool. J. Linn. Soc. 2020, zlaa146. [CrossRef]

418. De Assis, J.E.; de Souza, J.R.B.; de Lima, M.M.; de Lima, G.V.; Cordeiro, R.T.S.; Pérez, C.D. Association between deep-water scale-worms (Annelida: Polynoidae) and black corals (Cnidaria: Antipatharia) in the Southwestern Atlantic. Zoologia 2019, 36, 1-13. [CrossRef]

419. Barnich, R.; Beuck, L.; Freiwald, A. Scale worms (Polychaeta: Aphroditiformia) associated with cold-water corals in the eastern Gulf of Mexico. J. Mar. Biol. Assoc. UK 2013, 93, 2129-2143. [CrossRef]

420. Miranda, V.d.R.; Brasil, A.C.S. Two new species and a new record of Scale-worms (Polychaeta) from Southwest Atlantic deep-sea coral mounds. Zootaxa 2014, 3856, 211-226. [CrossRef]

421. Schiaparelli, S.; Alvaro, M.C.; Bohn, J.; Albertelli, G. 'Hitchhiker' polynoid polychaetes in cold deep waters and their potential influence on benthic soft bottom food webs. Antarct. Sci. 2010, 22, 399-407. [CrossRef]

422. Pettibone, M.H. A new scale worm commensal with deep-sea mussels in the seep-sites at the Florida Escarpment in the Eastern Gulf of Mexico (Polychaeta: Polynoidae: Branchipolynoidae). Proc. Biol. Soc. Wash. 1986, 99, 444-451.

423. Petersen, M.E.; Britayev, T.A. A new genus and species of polynoid scaleworm commensal with Chaetopterus appendiculatus Grube from the Banda Sea (Annelida: Polychaeta), with a review of commensals of Chaetopteridae. Bull. Mar. Sci. 1997, 60, 261-276.

424. Britayev, T.A.; Mekhova, E.; Deart, Y.; Martin, D. Do syntopic host species harbour similar symbiotic communities? The case of Chaetopterus spp. (Annelida: Chaetopteridae). PeerJ 2017, 5, e2930. [CrossRef]

425. Peters, W.C.H. Über die Gattung Bdella, Savigny, (Limnatis, Moquin-Tandon) und die in Mossambique beobachteten Anneliden, wovon hier eine Mittheilung folgt [informal title in meeting report]. Ber. Über Die Zur Bekanntm. Geeigneten Verh. Königlichen Preuss. Akad. Wiss. Zu Berl. 1854, 21, 607-614.

426. Britayev, T.A.; Zamyshliak, E.A. Association of the commensal scaleworm Gastrolepidia clavigera (Polychaeta: Polynoidae) with holothurians near the coast of South Vietnam. Ophelia 1996, 45, 175-190. [CrossRef]

427. Dales, R.P. Interrelations of organisms. A. Commensalism. In Treatise on marine ecology and palaeecology (Ed. J.W. Hedgpeth). Mem. Geol. Soc. Am. 1957, 67, 391-412.

428. Wagner, R.H.; Phillips, D.W.; Standing, J.D.; Hand, C. Commensalism or mutualism: Atraction of a sea star towards a symbiotic polychaete. J. Exp. Mar. Biol. Ecol. 1979, 39, 205-210. [CrossRef] 
429. Di Camillo, C.G.; Martin, D.; Britayev, T.A. Symbiotic association between Solanderia secunda (Cnidaria, Hydrozoa, Solanderiidae) and Medioantenna variopinta sp. nov. (Annelida, Polychaeta, Polynoidae) from North Sulawesi (Indonesia). Helgol. Mar. Res. 2011, 65, 495-511. [CrossRef]

430. Inaba, M. Soshu, Miura, Misaki ni oide edaru Hydroidea. [The hydroids collected at Miura and Misaki in Soshu.]. Zool. Mag. 1892, 4, 124-131.

431. Sars, G.O. Bidrag til Kundskaben om Dyrelivet paa vore Havbanker. Forh. Vidensk. Selsk. I Christiania 1873, 1872, 73-119.

432. Britayev, T.A.; Mekhova, E.S. Assessment of hidden diversity of crinoids and their symbionts in the Bay of Nhatrang, Vietnam. Org. Divers. Evol. 2011, 11, 275-286. [CrossRef]

433. Marudhupandi, T.; Kumar, T.T.A.; Prakash, S.; Gopi, M.; Balasubramanian, T. A first report of symbiotic polychaete scale worm Gastrolepidia clavigera Schmarda, 1861 (Phyllodocida: Polynoidae) from Lakshadweep Archipelago, India. J. Treatened Taxa 2014, 6, 3685-6388. [CrossRef]

434. Britayev, T.A.; Lyskin, S.A. Feeding of the symbiotic polychaete Gastrolepidia clavigera (Polynoidae) and its interactions with its hosts. Dokl. Biol. Sci. 2002, 385, 352-356. [CrossRef]

435. Hanley, J.R. A new host and locality records of the commensal Adyte crinoidicola (Polychaeta, Polynoidae). Beagle Rec. Mus. Art Gall. North. Territ. 1984, 1, 87-92.

436. Hanley, J.R. Revision of the scaleworm genera Arctonoe Chamberlin and Gastrolepidia Schmarda (Polychaeta, Polynoidae) with the erection of a new subfamily, Arctonoinae. Beagle Rec. Mus. Art Gall. North. Territ. 1989, 6, 1-34.

437. Sugiyama, T.; Jimi, N.; Goto, R. Widening the host range of the ectosymbiotic scale-worm Asterophilia culcitae (Annelida: Polynoidae) to three echinoderm classes, with data on its body color variation. Plankton Benthos Res. 2020, 15, 289-295. [CrossRef]

438. Willey, A. Report on the Polychaeta collected by Professor Herdman, at Ceylon, in 1902. Rep. Gov. Ceylon Pearl Oys 1905, 30, 212-324.

439. Johnson, H.P. A preliminary account of the marine annelids of the Pacific coast, with descriptions of new species. Proc. Calif. Acad. Sci. 1897, 1, 153-199.

440. Britayev, T.A.; Ivashchenko, N.I.; Litvinov, E.G. Peculiarities of the commensal complex in the polychaete Arctonoe vittata. Biol. Morya 1977, 1978, 76-78. (In Russian)

441. Park, T.; Lee, S.; Kim, W. New record of commensal scale worms, Arctonoe vittata (Grube, 1855) and Hyperhalosydna striata (Kinberg, 1856)(Polychaeta: Polynoidae) from Korean waters. J. Species Res. 2016, 5, 517-529. [CrossRef]

442. Tokaji, H.i.; Nakahara, K.; Goshima, S. Host switching improves survival rate of the symbiotic polychaete Arctonoe vittata. Plankton Benthos Res. 2014, 9, 189-196. [CrossRef]

443. Davenport, D. Studies in the physiology of commensalism. I. The polynoid genus Arctonoë. Biol. Bull. 1950, 98, 81-93. [CrossRef] [PubMed]

444. Montagu, G., II. Description of several Marine Animals found on the South Coast of Devonshire. Trans. Linn. Soc. Lond. 1808, 9 , 81-114. [CrossRef]

445. Conradi, M.; Bandera, M.E.; Marin, I.; Martin, D. Polychaete-parasitizing copepods from the deep-sea Kuril-Kamchatka Trench (Pacific Ocean), with the description of a new species of Ophelicola. Deep Sea Res. Part II Top. Stud. Oceanogr. 2015, 111, 147-165. [CrossRef]

446. Capa, M.; Aguado, M.T.; Bakken, T. Phylogenetic hypothesis of Sphaerodoridae Malmgren, 1867 (Annelida) and its position within Phyllodocida. Cladistics 2016, 32, 335-350. [CrossRef]

447. Capa, M.; Bakken, T. Revision of the Australian Sphaerodoridae (Annelida) including the description of four new species. Zootaxa 2015, 4000, 227-267. [CrossRef] [PubMed]

448. Ruderman, L. Recherches sur Ephesia gracilis Rathke, Annélide polychète de la famille des sphaerodorides; morphologie, anatomie, histologie. Mém. Soc. Zool. Fr. 1911, 24, 1-96.

449. Reimers, H. Morphologie der Polychaetengattung Sphaerodorum. Monographie. Zool. Jahrbücherabteilung Syst. Ökologie Und Geogr. Tiere 1933, 64, 41-110.

450. Capa, M.; Bakken, T.; Meißner, K.; Nygren, A. Three, two, one! Revision of the long-bodied sphaerodorids (Sphaerodoridae, Annelida) and synonymization of Ephesiella, Ephesiopsis and Sphaerodorum. PeerJ 2018, 6, e5783. [CrossRef]

451. Capa, M.; Osborn, K.J.; Bakken, T. Sphaerodoridae (Annelida) of the deep Northwestern Atlantic, including remarkable new species of Euritmia and Sphaerephesia. ZooKeys 2016, 615, 1-32. [CrossRef]

452. Capa, M.; Rouse, G.W. Sphaerodoridae (Annelida) from Lizard Island, Great Barrier Reef, Australia, including the description of two new species and reproductive notes. Zootaxa 2015, 4019, 168-183. [CrossRef] [PubMed]

453. Capa, M.; Nygren, A.; Parapar, J.; Bakken, T.; Meißner, K.; Moreira, J. Systematic re-structure and new species of Sphaerodoridae (Annelida) after morphological revision and molecular phylogenetic analyses of the North East Atlantic fauna. ZooKeys 2019, 845, 1-97. [CrossRef]

454. Lützen, J. Sur une nouvelle espèce de Polychète, Sphaerodoridium commensalis n. gen., n. spec. (Polychaeta Errantia, famille des Sphaerodoridae) vivant en commensal de Terebellides stroemi Sars. Cah. Biol. Mar. 1961, 2, 409-416.

455. Fauchald, K. Sphaerodoridae (Polychaeta: Errantia) from world-wide areas. J. Nat. Hist. 1974, 8, 257-289. [CrossRef]

456. Desbruyères, D. Sphaerodoridae (Annélides Polychètes) profonds du Nord-Est Atlantique. Bull. Mus. D’hist. Nat. Paris 1980, 4, 109-128. 
457. Kudenov, J.D. Five new species of Sphaeroridae (Annelida: Polychaeta) from the Gulf of Mexico. Proc. Biol. Soc. Wash. 1987, 100, 927-935.

458. Sardá-Borroy, R. Sphaerodoridae (Annelida, Polychaeta) from the region of the Gibraltar strait with description of Euritmia hamulisetosa gen. et sp. n. Zool. Scr. 1987, 16, 47-50. [CrossRef]

459. Rizzo, A.E. A new species of Ephesiopsis (Polychaeta: Sphaerodoridae) from off southeastern Brazil. Zootaxa 2009, $2307,61-67$. [CrossRef]

460. Helm, C.; Capa, M. Comparative analyses of morphological characters in Sphaerodoridae and allies (Annelida) revealed by an integrative microscopical approach. Front. Mar. Sci. 2015, 1, 1-15. [CrossRef]

461. Martin, D.; Alvà, V. Sphaerodorum ophiurophoretos n. sp., une nouvelle éspece de Sphaerodoridae (Annelida, Polychaeta) commensal sur Amphipholis squamata (Echinodermata, Ophiuridae). Bull. L'inst. R. Des. Sci. Nat. Belg. Biol. 1988, 58, 45-49.

462. Moore, J.P. Polychaetous annelids from Monterey Bay and San Diego, California. Proc. Acad. Nat. Sci. Phila. 1909, 61, $235-295$.

463. Moreira, J.; Parapar, J. Sphaerodoridae (Annelida: Polychaeta) from the Bellingshausen Sea (Antarctica) with the description of two new species. Polar Biol. 2011, 34, 193-204. [CrossRef]

464. Fauvel, P. Annélides Polychètes. Duc d'Orleans' Campagne Arctique de 1907; Charles Bulens: Brussels, Belgium, $1911 ;$ p. 45.

465. Kudenov, J.D. Four species of Sphaerodoridae (Anellida: Polychaeta) including one new genus and three new species from Alaska. Proc. Biol. Soc. Wash. 1987, 100, 917-926.

466. Borowski, C. Three new deep-sea species of Sphaerodoridae (Annelida, Polychaeta) from the eastern tropical South Pacific. Zool. Scr. 1994, 23, 193-203. [CrossRef]

467. Pleijel, F. Sphaerodoridae Malmgren, 1867. In Polychaetes; Rouse, G.W., Pleijel, F., Eds.; Oxford University Press: Oxford, UK, 2001; pp. 136-138.

468. Capa, M.; Bakken, T.; Purschke, G. Sphaerodoridae Malmgren, 1867; De Gruyter: Ösnabruck, Germany, 2014.

469. Hartmann-Schröder, G. Zur kenntnis des eulitorals der Australischen küsten unter besonderer berücksichigung de Polychaeten und Ostracoden. Teil 6. Die Polychaeten der tropisch-subtropischen westküste Australiens (zwischen Exmouth im Norden und Cervantes im Süden). Mitt. Hambg. Zool. Mus. Inst. 1981, 78, 19-96.

470. Moreira, J.; Parapar, J. Two new species of Sphaerodoropsis Hartman \& Fauchald, 1971 (Polychaeta: Sphaerodoridae) from Iceland (BIOICE programme). Mar. Biol. Res. 2012, 8, 584-593. [CrossRef]

471. Villora-Moreno, S. Environmental heterogeneity and the biodiversity of interstitial Polychaeta. Bull. Mar. Sci. 1997, 60, 494-501.

472. Worsaae, K.; Kristensen, R.M. Evolution of interstitial Polychaeta (Annelida). In Morphology, Molecules, Evolution and Phylogeny in Polychaeta and Related Taxa; Springer: Berlin/Heidelberg, Germany, 2005; pp. 319-340.

473. Spalding, M.D.; Fox, H.E.; Allen, G.R.; Davidson, N.; Ferdaña, Z.A.; Max, F.; Halpern, B.S.; Jorge, M.A.; Lombana, A.; Lourie, S.A.; et al. Marine ecoregions of the world: A bioregionalization of coastal and shelf areas. Bioscience 2007, 57, 573-583. [CrossRef]

474. Agassiz, A. On alternate generation of annelids and the embryology of Autolytus cornutus. J. Boston Soc. Nat. Hist. 1862, 7, 384-409.

475. Langerhans, P. Die Wurmfauna von Madeira [part I]. Z. Wiss. Zool. 1879, 32, 513-592.

476. Malaquin, A. Recherches sur les syllidiens: Morphologie, anatomie, reproduction, développement. Mém. Soc. Des. Sci. L'agric. Des. Arts Lille4e Sér. 1893, 18, 1-477.

477. Rioja, E. Anélidos poliquetos de San Vicente de la Barquera (Cantábrico). Trab. Mus. Nac. Cienc. Nat. Ser. Zool. 1925, 53, 1-62.

478. Aguado, M.T.; San Martín, G. Phylogeny of Syllidae (Polychaeta) based on morphological data. Zool. Scr. 2009, 38, 379-402. [CrossRef]

479. San Martín, G. Annelida, Polychaeta II: Syllidade. In Fauna Iberica., vol. 21; Ramos, M.A., Alba, J., Bellés, X., Gosálbez, J., Guerra, A., Macpherson, E., Serrano, J., Templado, J., Eds.; CSIC: Madrid, Spain, 2003; Volume 21, p. 554.

480. San Martín, G.; Aguado, M.T. Family Syllidae. In Handbook of Zoology Online, Annelida; De Gruyter: Berlin, Germany, 2014; pp. $1-52$.

481. Müller, O.F. Von Würmern des Süssen und Salzigen Wassers; H. Mumme and Faber: Copenhagen, Denmark, $1771 ;$ p. 200.

482. Audouin, J.V.; Milne-Edwards, H. Recherches pour Servir a L'histoire Naturelle du Littoral de la France, ou, Recueil de Mémoires sur L'anatomie, la Physiologie, la Classification et les Moeurs des Animaux des nos Côtes: Ouvrage Accompagné de Planches Faites D'après Nature; Crochard: Paris, France, 1834.

483. Licher, F. Revision der Gattung Typosyllis Langerhans, 1879 (Polychaeta: Syllidae). Morphologie, Taxonomie und Phylogenie. Abh. Senckenbergischen Nat. Ges. 1999, 551, 1-336.

484. Nygren, A. Phylogeny and reproduction in Syllidae (Polychaeta). Zool. J. Linn. Soc. Lond. 1999, 126, 365-386. [CrossRef]

485. Nygren, A.; Sundberg, P. Phylogeny and evolution of reproductive modes in Autolytinae (Syllidae, Annelida). Mol. Phylogenet. Evol. 2003, 29, 235-249. [CrossRef]

486. Aguado, M.T.; Martin, S.; Siddall, G. Systematics and evolution of syllids. Annelidasyllidae. Cladistics 2012, 28, 234-250. [CrossRef]

487. Aguado, M.T.; Nygren, A.; Siddall, M.E. Phylogeny of Syllidae (Polychaeta) based on combined molecular analysis of nuclear and mitochondrial genes. Cladistics 2007, 23, 552-564. [CrossRef]

488. Nygren, A. Revision of Autolytinae (Syllidae: Polychaeta). Zootaxa 2004, 680, 1-314. [CrossRef]

489. San Martín, G.; López, E.; Aguado, M.T. Revision of the genus Pionosyllis (Polychaeta: Syllidae: Eusyllinae), with a cladistic analysis, and the description of five new genera and two new species. J. Mar. Biol. Assoc. UK 2009, 1-44. [CrossRef] 
490. Aguado, M.T.; Bleidorn, C. Conflicting signal within a single gene confounds syllid phylogeny (Syllidae, Annelida). Mol. Phylogenet. Evol. 2010, 55, 1128-1138. [CrossRef] [PubMed]

491. Day, J.H. The polychaete fauna of South Africa Part 8: New species and records from grab samples and dredgings. Bull. Br. Mus. Nat. Hist. 1963, 10, 381-445. [CrossRef]

492. Aguado, M.T.; Glasby, C.J.; Schroeder, P.1.C.; Weigert, A.; Bleidorn, C. The making of a branching annelid: An analysis of complete mitochondrial genome and ribosomal data of Ramisyllis multicaudata. Sci. Rep. 2015, 5, 12072. [CrossRef]

493. Augener, H. Polychaeta I. Errantia. In Die Fauna Südwest-Australiens. Ergebnisse der Hamburger Südwest-Australischen Forschungsreise 1905; Michaelsen, W., Hartmeyer, R., Eds.; Gustav Fischer: Jena, Germany, 1913; Volume IV, pp. 65-304.

494. San Martín, G.; Hutchings, P. Eusyllinae (Polychaeta: Syllidae) from Australia with the description of a new genus and fifteen new species. Rec. Aust. Mus. 2006, 58, 257-370. [CrossRef]

495. Aguado, M.T.; Murray, A.; Hutchings, P.A. Syllidae (Annelida: Phyllodocida) from Lizard Island, Great Barrier Reef, Australia. Zootaxa 2015, 4019, 35-60. [CrossRef]

496. Martínez, M.J.; San Martin, G. Syllidae (Annelida) from East Timor and the Philippines (Pacific Ocean), with the description of three new species of Syllis Savigny in Lamarck, 1818. Zootaxa 2020, 4834, 231-263. [CrossRef]

497. Hartmann-Schröder, G. Die Polychaeten der tropischen Nordwestküste Australiens (Zwischen Port Samson in Norden und Port Hedland in Süden). Teil 2. In: Hartmann-Schröder, G. and Hartmann, G. (eds.), Zur Kenntnis des Eulitorals der australischen Küsten unter besonder Berücksichtigung der Polychaeten und Ostracoden. Mitt. Hambg. Zool. Mus. Inst. 1979, 76, 75-218.

498. Glasby, C.J.; Watson, C. A new genus and species of Syllidae (Annelida: Polychaeta) commensal with octocorals. Beagle Rec. Mus. Art Gall. North. Territ. 2001, 17, 43-51.

499. Glasby, C.J.; Schroeder, P.C.; Aguado, M.T. Branching out: A remarkable new branching syllid (Annelida) living in a Petrosia sponge (Porifera: Demospongiae). Zool. J. Linn. Soc. 2012, 164, 481-497. [CrossRef]

500. Ribeiro, R.P.; Ponz-Segrelles, G.; Helm, C.; Egger, B.; Aguado, M.T. A new species of Syllis Grube, 1850 including transcriptomic data and an updated phylogeny of Syllinae (Annelida: Syllidae). Mar. Biodivers. 2020, 50, 31. [CrossRef]

501. Aguado, M.T.; Richter, S.; Sontowski, R.; Golombek, A.; Struck, T.H.; Bleidorn, C. Syllidae mitochondrial gene order is unusually variable for Annelida. Gene 2016, 594, 89-96. [CrossRef] [PubMed]

502. Álvarez-Campos, P.; Riesgo, A.; Hutchings, P.; San Martin, G. The genus Syllis Savigny in Lamarck, 1818 (Annelida, Syllidae) from Australia. Molecular analysis and re-description of some poorly-known species. Zootaxa 2015, 4052, 297-331. [CrossRef]

503. Ponz-Segrelles, G.; Ribeiro, R.P.; Bleidorn, C.; Aguado, M.T. Sex-specific gene expression differences in reproducing Syllis prolifera and Nudisyllis pulligera (Annelida, Syllidae). Mar. Genom. 2020, 100772. [CrossRef] [PubMed]

504. Ponz-Segrelles, G.; Bleidorn, C.; Aguado, M.T. Expression of vasa, piwi, and nanos during gametogenesis in Typosyllis antoni (Annelida, Syllidae). Evol. Dev. 2018, 20, 132-145. [CrossRef]

505. Ribeiro, R.P.; Ponz-Segrelles, G.; Bleidorn, C.; Aguado, M.T. Comparative transcriptomics in Syllidae (Annelida) indicates that posterior regeneration and regular growth are comparable, while anterior regeneration is a distinct process. Bmc Genom. 2019, 20, 855. [CrossRef]

506. San Martín, G.; Álvarez-Campos, P.; Hutchings, P. The genus Syllis Savigny in Lamarck, 1818 (Annelida: Syllidae: Syllinae) from Australia (second part): Four new species and re-description of twelve previously described species. Zootaxa 2017, 4237, 201-243. [CrossRef] [PubMed]

507. Aguado, M.T.; San Martín, G. Re-description of some enigmatic genera of Syllidae (Phyllodocida: Polychaeta). J. Mar. Biol. Assoc. United Kingd. 2008, 88, 35-56. [CrossRef]

508. Fukuda, M.V.; San Martin, G.; Carrerette, O.; Paresque, K. On a new species of the rare syllid genus Exogonoides (Annelida, Phyllodocida, Syllidae). Zootaxa 2016, 4144, 291-295. [CrossRef]

509. Claparède, É. Glanures zootomiques parmi les annélides de Port-Vendres (Pyrénées Orientales). Mém. Soc. Phys. D’hist. Nat. Gen. 1864, 17, 463-600.

510. McIntosh, W.C. On a remarkably branched Syllis dredged by H.M.S. Challenger. J. Linn. Soc. 1879, 14, 720-724. [CrossRef]

511. Pleijel, F. Syllidae Grube, 1850. In Polychaetes; Rouse, G.W., Pleijel, F., Eds.; Oxford University Press: Oxford, UK, 2001 ; pp. 102-105.

512. San Martín, G.; Aguado, M.T. Contribution of Scanning Electron Microscope to the study of morphology, biology, reproduction, and phylogeny of the family Syllidae (Polychaeta). In Scanning Electron Microscopy; Kazmiruk, V., Ed.; IntechOpen: Rijeka, Croatia, 2012; Volume 8, pp. 129-145.

513. Westheide, W.; Hass-Cordes, E. Molecular taxonomy: Description of a cryptic Petitia species (Polychaeta: Syllidae) from the island of Mahé (Seychelles, Indian Ocean) using RAPD markers and ITS2 sequences. J. Zool. Syst. Evol. Res. 2001, 39, 103-111. [CrossRef]

514. Di Domenico, M.; da Cunha Lana, P.; Garraffoni, A.R.S. Distribution patterns of interstitial polychaetes in sandy beaches of southern Brazil. Mar. Ecol. 2009, 30, 47-62. [CrossRef]

515. Nogueira, J.M.M.; San Martín, G.; Fukuda, M.V. On some exogonines (Polychaeta, Syllidae, Exogoninae) from the northern coast of the State of São Paulo, southeastern Brazil. Results of BIOTA/FAPESP/Bentos Marinho Project. Meiofauna Mar. 2004, 13 , 45-77.

516. Riera, R.; Núñez, J.; Brito, M.C. A new species of the interstitial genus Neopetitia (Polychaeta, Syllidae, Eusyllinae) from Tenerife, with modified acicular chaetae in males. Helgol. Mar. Res. 2007, 61, 221-223. [CrossRef]

517. Barroso, R.; Paiva, P.C.D.; Nogueira, J.M.D.M.; Fukuda, M.V. Deep sea Syllidae (Annelida, Phyllodocida) from Southwestern Atlantic. Zootaxa 2017, 4221, 401-430. [CrossRef] [PubMed] 
518. Böggemann, M.; Purschke, G. Abyssal benthic Syllidae (Annelida: Polychaeta) from the Angola Basin. Org. Divers. Evol. 2005, 5, 221-226. [CrossRef]

519. San Martín, G. Deep sea Syllidae from the Pacific Ocean collected during cruises with the RV Sonne (Annelida, Polychaeta, Syllidae). Senckenbergiana Biol. 2004, 84, 13-25.

520. Hortal, J.; Jiménez-Valverde, A.; Gómez, J.F.; Lobo, J.M.; Baselga, A. Historical bias in biodiversity inventories affects the observed environmental niche of the species. Oikos 2008, 117, 847-858. [CrossRef]

521. Lomolino, M.V. Conservation Biogeography. Frontiers of Biogeography: New Directions in the Geography of Nature; Lomolino, M.V., Heaney, L.R., Eds.; Sinauer Associates: Sunderland, MA, USA, 2004; pp. 293-296.

522. San Martín, G. Estudio Biogeográfico, Faunístico y Sistemático de los Poliquetos de la Familia Sílidos (Syllidae, Polychaeta) en Baleares. Ph.D. Thesis, Universidad Complutense, Madrid, Spain, 1984.

523. Perkins, T.H. Syllidae (Polychaeta), principlally from Florida, with descriptions of a new genus and twenty-one new species. Proc. Biol. Soc. Wash. 1980, 93, 1080-1172.

524. Uebelacker, J.M. Chapter 30. Family Syllidae. In Taxonomic Guide to the Polychaetes of the Northern Gulf of Mexico; Uebelacker, J.M., Johnson, P.G., Eds.; Barry A. Vitor \& Associated: Mobile, AL, USA, 1984; pp. 1-151.

525. San Martín, G. Eusyllinae (Syllidae, polychaeta) from Cuba and Gulf of Mexico. Bull. Mar. Sci. 1990, 46, 590-619.

526. San Martín, G. Grubeosyllis and Exogone (Exogoninae, Syllidae, Polychaeta) from Cuba, the Gulf of Mexico, Florida and Puerto Rico, with a revision of Exogone. Bull. Mar. Sci. 1991, 49, 715-740.

527. San Martín, G. Syllis Savigny in Lamarck, 1818 (Polychaeta: Syllidae: Syllinae) from Cuba, The Gulf of Mexico, Florida and North Carolina, with a revision of several species described by Verrill. Bull. Mar. Sci. 1992, 51, 167-196.

528. Capa, M.; San Martín, G.; López, E. Syllinae (Syllidae: Polychaeta) del Parque Nacional de Coiba, Panamá. Rev. Biol. Trop. 2001, $49,103-115$.

529. Capa, M.; San Martín, G.; López. E. Autolytinae, Eusyllinae y Exogoninae (Syllidae: Polychaeta) del Parque Nacional de Coiba, Panamá. Rev. Biol. Trop. 2001, 49, 621-628.

530. Hartmann-Schröder, G. Zur kenntnis des eulitorals des Australischen küsten unter besonderer berücksichtigung der Polycheten und Ostracoden. Teil 2. Die Polychaeten der tropischen Nord westküste Australiens (zwischen Derby im Nordem und Port Hedland im Südem). Mitt. Hambg. Zool. Mus. Inst. 1979, 76, 75-218.

531. Hartmann-Schröder, G. Die Polychaeten der subtropisch-tropischen bis tropischen Ostkueste Australiens zwischen Maclean (New South Wales) und Gladstone (Queensland) sowie von Heron Island (Grosses Barrier Riff) IN: Hartmann-Schröder, Gesa and Gerd Hartmann. Zur Kenntnis des eulitorals der australischen Kuesten unter besounderer Beruecksichtigung des Polychaeten und Ostracoden. Teil 16. Mitt. Hambg. Zool. Mus. Inst. 1991, 88, 17-71.

532. San Martin, G. Exogoninae (Polychaeta:Syllidae) from Australia with the description of a new genus and twenty-two new species. Rec. Aust. Mus. 2005, 57, 39-152. [CrossRef]

533. San Martín, G.; Hutchings, J.A.; Aguado, M.T. Syllinae (Polychaeta: Syllidae) from Australia. Part 1. Genera Branchiosyllis, Eurysyllis, Karroonsyllis, Parasphaerosyllis, Plakosyllis, Rhopalosyllis, Tetrapalpia n.gen., and Xenosyllis. Rec. Aust. Mus. 2008, 60, 119-160. [CrossRef]

534. San Martín, G.; Hutchings, P.; Aguado, M.T. Syllinae (Polychaeta: Syllidae) from Australia. Part 3. Genera Alcyonosyllis, Genus A, Parahaplosyllis, and Trypanosyllis (Trypanobia). Zootaxa 2010, 2493, 35-48. [CrossRef]

535. Musco, L.; Giangrande, A. A new sponge-associated species, Syllis mayeri n. sp.(Polychaeta: Syllidae), with a discussion on the status of S. armillaris (Müller, 1776). Sci. Mar. 2005, 69, 467-474. [CrossRef]

536. Musco, L.; Giangrande, A. Mediterranean Syllidae (Annelida: Polychaeta) revisited: Biogeography, diversity and species fidelity to environmental features. Mar. Ecol. Prog. Ser. 2005, 304, 143-153. [CrossRef]

537. Bianchi, C.N. Biodiversity issues for the forthcoming tropical Mediterranean Sea. Hydrobiologia 2007, 580, 7-21. [CrossRef]

538. Mikac, B.; Musco, L. Faunal and biogeographic analysis of Syllidae (Polychaeta) from Rovinj (Croatia, northern Adriatic Sea). Sci. Mar. 2010, 74, 353-370. [CrossRef]

539. Hutchings, P.A.; Lavesque, N. I know who you are, but do others know? Why correct scientific names are so important for the biological sciences. Zoosymposia 2020, 19, 151-163. [CrossRef]

540. Lattig, P.; San Martín, G.; Martin, D. Taxonomic and morphometric analyses of the Haplosyllis spongicola complex (Polychaeta: Syllidae: Syllinae) from Spanish seas, with re-description of the type species and descriptions of two new species. Sci. Mar. 2007, 71, 551-570. [CrossRef]

541. Lattig, P.; Martin, D. A taxonomic revision of the genus Haplosyllis Langerhans, 1887 (Polychaeta: Syllidae: Syllinae). Zootaxa 2009, 2220, 1-40. [CrossRef]

542. Muniz, P.; Pires, A.M.S. Trophic structure of polychaetes in the São Sebastião Channel (southeastern Brazil). Mar. Biol. 1999, 134, 517-528. [CrossRef]

543. Pagliosa, P.R. Another diet of worms: The applicability of polychaete feeding guilds as a useful conceptual framework and biological variable. Mar. Ecol. 2005, 26, 246-254. [CrossRef]

544. Giangrande, A.; Licciano, M.; Pagliara, P. The diversity of diets in Syllidae (Annelida: Polychaeta). Cah. Biol. Mar. 2000, 41, 55-65.

545. Álvarez-Campos, P.; Fernández-Leborans, G.; Verdes, A.; San Martín, G.; Martin, D.; Riesgo, R. The tag-along friendship: Epibiotic protozoans and syllid polychaetes. Implications for the taxonomy of Syllidae (Annelida), and description of three new species of Rhabdostyla and Cothurnia (Ciliophora, Peritrichia). Zool. J. Linn. Soc. 2014, 17, 265-281. [CrossRef] 
546. Siddall, M.E.; Aguado, M.T. Molecular phylogenetic evidence of a haplosporidian parasite infecting the polychaete Syllis nipponica (Imajima, 1966). Parasitol. Res. 2006, 99, 309-312. [CrossRef]

547. Lattig, P.; Martin, D. Sponge-associated Haplosyllis (Polychaeta: Syllidae: Syllinae) from the Caribbean Sea, with the description of four new species. Sci. Mar. 2011, 75, 733-758. [CrossRef]

548. Paresque, K.; Nogueira, J.M.M. The genus Haplosyllis Langerhans, 1879 (Polychaeta: Syllidae) from northeastern Brazil, with descriptions of two new species. Mar. Biol. Res. 2014, 10, 554-576. [CrossRef]

549. Glasby, C.J.; Aguado, M.T. A new species and new records of the anthozoan commensal genus Alcyonosyllis (Polychaeta: Syllidae). Beagle Rec. Mus. Art Gall. North. Territ. 2009, 25, 55-63. 